\title{
ASSOCIAÇÃO TERAPÊUTICA DOS QUIMIOTERÁPICOS GENCITABINA E DOXORRUBICINA E CÉLULAS-TRONCO MESENQUIMAIS NO MODELO ORTOTÓPICO DE CARCINOMA HEPATOCELULAR
}

\author{
Dissertação apresentada à Faculdade de \\ Medicina da Universidade de São Paulo para \\ obtenção de título de Mestre em Ciências \\ Programa de Pós-graduação Ciências Médicas \\ Área de concentração: Distúrbios do \\ Crescimento Celular, Hemodinâmicos e de \\ Hemostasia \\ Orientador: Prof. Dr. Durvanei Augusto Maria
}

(Versão corrigida. Resolução CoPGr 6018/11, de 1 de novembro de 2011. A versão original está disponível na Biblioteca da FMUSP) 


\section{ASSOCIAÇÃO TERAPÊUTICA DOS QUIMIOTERÁPICOS GENCITABINA E DOXORRUBICINA E CÉLULAS-TRONCO MESENQUIMAIS NO MODELO ORTOTÓPICO DE CARCINOMA HEPATOCELULAR}

Dissertação apresentada à Faculdade de Medicina da Universidade de São Paulo para obtenção de título de Mestre em Ciências

Programa de Ciências Médicas

Área de Concentração: Distúrbios do Crescimento Celular, Hemodinâmicos e da Hemostasia

Orientador: Prof. Dr. Durvanei Augusto Maria 


\section{SUMÁRIO}

LISTA DE ABREVIATURAS, SÍMBOLOS E SIGLAS

LISTA DE FIGURAS

RESUMO 5

ABSTRACT

1 INTRODUÇÃO

$\begin{array}{lr}1.1 \text { Carcinoma hepatocelular } & \mathbf{1 2}\end{array}$

$\begin{array}{ll}\text { 1.1.1 Etiologia e fatores de risco } & \mathbf{1 4}\end{array}$

$\begin{array}{ll}1.2 \text { Quimioterapia } & \mathbf{1 5}\end{array}$

1.2.1 Hepatotoxicidades causadas pela quimioterapia $\mathbf{1 6}$

$\begin{array}{ll}1.3 \text { Fígado } & 17\end{array}$

1.3.1 Estrutura morfofuncional hepática do camundongo $\quad \mathbf{1 8}$

$\begin{array}{ll}\text { 1.3.2 Regeneração hepática } & 19\end{array}$

1.4 Terapia celular $\quad \mathbf{2 2}$

$\begin{array}{ll}1.5 \text { Células-tronco } & \mathbf{2 3}\end{array}$

2 JUSTIFICATIVA 28

OBJETIVOS 29

IMPACTOS ESPERADOS

5 MATERIAS E MÉTODOS 31

5.1 Modelo experimental ortotópico de carcinoma hepatocelular $\begin{array}{ll}\text { em camundongos } & \mathbf{3 1}\end{array}$

5.2 Análise do perfil hematológico

5.3 Avaliação da redução do volume do tumor hepático 34

5.4 Cultura celular (Hepa1c1c7)

5.5 Determinação da atividade citotóxica dos quimioterápicos

doxorrubicina e gencitabina em células de carcinoma hepatocelular murino (Hepa1c1c7) pelo método colorimétrico MTT 35

5.6 Determinação da peroxidação de lipídeos da membrana celular (TBARS) 36

5.7 Análises das fases do ciclo celular "in vitro" por citometria de fluxo $\quad 36$

5.8 Análises das fases do ciclo celular "in vivo” por citometria de fluxo $\quad 37$

5.9 Análise da expressão de marcadores "in vivo" por citometria de fluxo $3 \mathbf{3 8}$

5.10 Cultura de células-tronco mesenquimais da medula óssea (CTMO) 39 
5.10.1 Caracterização imunofenotípica das células-tronco mesenquimais da medula óssea de camundongos C57BL/6J

5.11 Análise histológica

5.12 Análises estatísticas

6 RESULTADOS

6.1 Modelo experimental ortotópico de carcinoma hepatocelular

6.2 análise do perfil hematológico e peso dos animais

6.3 Avaliação da redução do volume do tumor hepático

6.4 Determinação da atividade citotóxica dos quimioterápicos

doxorrubicina e gencitabina em células de carcinoma hepatocelular murino (Hepa1c1c7) pelo método colorimétrico MTT

6.5 Determinação da peroxidação de lipídeos da membrana celular

6.6 Aspectos citológicos da linhagem de carcinoma hepatocelular murino

(Hepac1c1c7)

6.7 Análises das fases do ciclo celular "in vitro" por citometria de fluxo

6.8 Análises das fases do ciclo celular "in vivo" por citometria de fluxo

6.9 Análise da expressão de marcadores “in vivo” por citometria de fluxo

6.10 Aspectos citológicos das células-tronco mesenquimais da medula óssea

6.10.1 Caracterização imunofenotípica das células-tronco mesenquimais da medula óssea de camundongos C57BL/6J

6.11 Análise histopatológica dos tumores e dos órgãos internos 


\section{RESUMO}

D'Agostino LG. Associação terapêutica dos quimioterápicos gencitabina e doxorrubicina e células-tronco mesenquimais no modelo ortotópico de carcinoma hepatocelular [Dissertação]. São Paulo: Faculdade de Medicina, Universidade de São Paulo; 2016.

O carcinoma hepatocelular (CHC) é a neoplasia maligna primária mais comum do fígado, sendo a quinta mais frequente e a terceira causa de morte por câncer no mundo. Atualmente, nenhum protocolo com resultados satisfatórios no tratamento de CHC foi preconizado. Neste estudo foi determinado o potencial regenerativo e imunomodulador das células-tronco mesenquimais (CTM) associadas ou não aos quimioterápicos doxorrubicina e gencitabina, no modelo ortotópico de $\mathrm{CHC}$ em camundongos C57BL/6J. Foi realizado in vitro a determinação da atividade citotóxica dos quimioterápicos doxorrubicina e gencitabina em células de CHC murino (Hepa1c1c7), quantificação da peroxidação de lipídeos da membrana celular (TBARS) e análise das fases do ciclo celular e a expressão de marcadores por citometria de fluxo. A IC50\% em células de carcinoma hepatocelular murino (Hepa1c1c7) foi de $1,85 \mu \mathrm{M}$ para doxorrubicina e 20,8 $\mu \mathrm{M}$ para gencitabina. A quantificação de TBARS na linhagem celular de CHC murino (Hepa1c1c7) tratados com os quimioterápicos doxorrubicina e gencitabina demonstrou efeito deletério apenas quando tratados nas concentrações $(55$ a $250 \mu \mathrm{M})$ com a doxorrubicina e $(1,75$ a $7 \mu \mathrm{M})$ com gencitabina. Após tratamento com os quimioterápicos, ocorreram modificações nas populações celulares, com o aumento da fase sub-G1 e G0/G1 e diminuição fases S e G2/M. As CTM, apresentaram-se aderentes aos frascos de cultura com morfologia semelhante a fibroblastos e expressão positiva para marcadores CD44, CD73, CD90 e CD105 e negativa para células-tronco hematopoiéticas da medula óssea: CD11b, CD45 e CD117. O modelo experimental tumoral ortotópico de $\mathrm{CHC}$ foi estabelecido no $21^{\circ}$ dia após a inoculação das células tumorais. Os efeitos da terapêutica com a CTM mostraram aspectos significativos na redução da massa tumoral $(30,5 \%)$, os demais grupos experimentais tratados com quimioterapia sistêmica associada à terapia celular também evidenciaram resultados significativos na redução da massa tumoral e atenuação dos efeitos de toxicidade sistêmica. As células tumorais extraídas dos tumores hepáticos encontram-se preferencialmente na fase sub-G1 nos grupos de animais tratados com CTM em associação aos quimioterápicos gencitabina (29\%) e doxorrubicina (21\%), enquanto o tratamento isolado com a doxorrubicina foi de $22 \%$ e de $15 \%$ para a gencitabina, além de induzir significativamente diminuição das fases S e G2/M. No grupo de animais tratado com CTM em associação ao quimioterápico gencitabina há um aumento da expressão das caspases 3 e 8 , e dos marcadores CD44 e IL-1R. O grupo de animais tratados com CTM apresentou aumento na expressão dos marcadores CD90 e CD14. Os resultados obtidos no tratamento do modelo ortotópico de CHC com CTM associadas aos quimioterápicos doxorrubicina e gencitabina apresentaram eficácia na redução da massa tumoral e atenuação dos efeitos colaterais causados pelo tratamento quimioterápico sistêmico, além do seu potencial efeito imunomodulador.

Descritores: carcinoma hepatocelular; gencitabina; doxorrubicina, células-tronco; imunidade; medula óssea. 


\begin{abstract}
D’Agostino LG. Therapeutic association of chemotherapics gemcitabine, doxorubicin and mesenchymal stem cells therapy in an orthotopic model of carcinoma hepatocellular [dissertation]. São Paulo: "Faculdade de Medicina, Universidade de São Paulo"; 2016.

Hepatocellular carcinoma (HCC) is the most common primary malignancy of the liver, the most frequent fifth and the third leading cause of cancer death in the world. Currently, no protocol with satisfactory results in the treatment of $\mathrm{CHC}$ was recommended. In this study we determined the regenerative potential immunomodulatory and mesenchymal stem cells (MSCs) associated or not to chemotherapy doxorubicin and gemcitabine, in the orthotopic model of CHC in C57BL / 6J mice. Was determined in vitro the cytotoxic activity of doxorubicin and gemcitabine chemotherapy in a murine cells (Hepalc1c7), quantification of cell membrane lipid peroxidation (TBARS) and analysis of the phases of the cell cycle and expression of markers by flow cytometry. IC50\% in murine carcinoma cells (Hepa1c1c7) was $1.85 \mathrm{uM}$ and $20.8 \mathrm{uM}$ for doxorubicin to gemcitabine. The quantification of TBARS in cell line (Hepalc1c7) treated with the chemotherapeutic doxorubicin and gemcitabine showed a deleterious effect only when treated at concentrations $(55-250 \mathrm{uM})$ doxorubicin and $(1.75$ to $7 \mathrm{uM})$ with gemcitabine. After treatment with chemotherapeutic agents, there were changes in the cell population, with increased phase sub-G1 and G0 / G1 phase and reduced S and G2 / M. MSC presented to adhere to culture flasks with morphology similar to fibroblasts and positive expression of markes: CD44, CD73, CD90 and CD105 and negative hematopoietic stem cells from bone marrow: CD11b, CD45 and CD117. The tumor orthotopic experimental model of HCC was established on day 21 after tumor cell inoculation. The effects of therapy CTM showed significant aspects in reducing the tumor mass (30.5\%), the other experimental groups treated with systemic chemotherapy associated with cell therapy also showed significant results in reducing the tumor mass and mitigation of systemic toxicity effects. The extracted tumor cells of liver tumors are preferably in the subG1 phase in groups of animals treated with MSC in association with gemcitabine (29\%) and doxorubicin $(21 \%)$ chemotherapy, whereas the single treatment with was $22 \%$ doxorubicin and $15 \%$ for gemcitabine in addition to significantly induce reduction of phases S and G2 / M. In the group of animals treated with MTC in combination with gemcitabine chemotherapy there is an increased expression of caspase 3 and 8 and IL-1R and CD44. The group of animals treated with MSCs showed increased markers expression of CD90 and CD14. The results obtained in the treatment of orthotopic HCC model with MSC associated with the chemotherapeutic doxorubicin and gemcitabine showed efficacy in reducing tumor burden and attenuation of the side effects caused by systemic chemotherapy, as well its potential immunomodulatory effect.
\end{abstract}

Descriptors: carcinoma, hepatocellular; gemcitabine; doxorubicin; stem cells; immunity; bone marrow. 


\section{LISTA DE ABREVIATURAS, SÍMBOLOS E SIGLAS}

ALT Alanina aminotransferase

ANOVA Análise estatística de variância

AST Aspartato aminotransferase

ATP Adenosina trifosfato

Bcl-2 Linfoma de células B-2

BMP-4 Bone morphogenetic protein-4

BSA Albumina de soro bovino

CFU-Fs Unidades de colônias formadoras de fibroblastos

CHC Carcinoma hepatocelular

CT Célula-tronco

CTM Célula-tronco mesenquimal

CTMO Células-tronco mesenquimais da medula óssea

DMEM Dulbecco's modified eagle medium

DNA Ácido desoxirribonucleico

EDTA Ácido etilenodiamino tetra-acético

Flt-3lig Ligante Flt-3 da tirosina kinase

G0/G1 Gap 0/Gap1

G2/M Gap 2/Mitose

GM-CSF Granulocyte macrophage colony-stimulating factor

GPI Glicofosfatidilinositol

HCC Hepatocellular carcinoma

HE Hematoxilina e eosina

IC50 Concentração inibitória 50\%

IgG Imunoglobulina $\mathrm{G}$

IL Interleucina

ISCT International Society for Cytotherapy

$\mathrm{KCl} \quad$ Cloreto de potássio

$\mathrm{KH}_{2} \mathrm{PO} 4$ Fosfato monopotássico

LIF Leukemia inhibitory

LPO Lipoperoxidação ou peroxidação lipídica 
LPS Lipopolissacarideos

Mac-1 Marcador de célula imune-integrina

M-CSF Macrophage colonystimulating factor

MDA Malondialdeído

$\mathrm{mmHg} \quad$ Milímetro de mercúrio

MMPs Metaloproteinases

MTT Brometo de 3-(4,5 - dimetilazol - 2-il) - 2,5 - difeniltetrazólio

$\mathrm{Na}_{2} \mathrm{HPO} 4$ Fosfato dissódico

$\mathrm{NaCl} \quad$ Cloreto de sódio

NADPH Fosfato de nicotinamida adenina dinucleotídeo reduzido

$\mathrm{NaHCO}^{3}$ Bicarbonato de sódio

nm Nanômetro

nM Nanomoles

oSM Oncostatina M

PCNA Proliferação celular

PI Iodeto de propídeo

$\mathrm{r}^{2} \quad$ Coeficiente de correlação

RNA Ácido ribonucleico

RNAse Enzima que degrada o RNA

S $\quad$ Fase de síntese de DNA

SCF Stem cell factor

SDF-1 Stromal derived factor

SFB Soro fetal bovino

TBA Ácido tiobarbitúrico

TBARS Substâncias reativas ao ácido tiobarbitúrico

TCA Ácido tricloroacético

TGF $\beta$ Fator de transformação do crescimento beta

TPo Thrombopoietin

VHB Vírus da hepatite B 


\section{LISTA DE FIGURAS}

Figura 1 Fotomicrografia de parênquima hepática do modelo ortotópico de carcinoma hepatocelular.

Figura 2 Fotomicrografia de parênquima do pulmão e linfonodo inguinal do modelo ortotópico de carcinoma hepatocelular.

Figura 3 Gráfico com análise do perfil hematológico e peso dos animais tratados com células-tronco mesenquimais e o quimioterápico doxorrubicina.

Figura 4 Gráfico com análise do perfil hematológico e peso dos animais tratados com células-tronco mesenquimais e o quimioterápico gencitabina.

Figura 5 Gráfico com análise da mensuração de reticulócitos.

Figura 6 Gráfico com análise do volume do tumor hepático.

Figura 7 Gráfico da viabilidade celular obtida pelo teste de MTT para determinação da $\mathrm{IC}_{50}$ em linhagem de carcinoma hepatocelular murino (Hepa1c1c7) após 24 horas de tratamento com os quimioterápicos doxorrubicina e gencitabina.

Figura 8 Valores das médias $\pm \mathrm{dp}$ dos radicais livres poli-insaturados peroxidados (Malondialdeído - MDA) formados no sobrenadante da linhagem de carcinoma hepatocelular murino (Hepa1c1c7) tratada com os quimioterápicos doxorrubicina e gencitabina.

Figura 9 Aspectos citológicos da linhagem de carcinoma hepatocelular murino (Hepac1c1c7) após 24 horas de tratamento com o quimioterápico doxorrubicina.

Figura 10 Aspectos citológicos da linhagem de carcinoma hepatocelular murino (Hepac1c1c7) após 24 horas de tratamento com o quimioterápico gencitabina.

Figura 11 Gráfico de barras das médias \pm dp das células de carcinoma hepatocelular murino (Hepa1c1c7) tratadas com as concentrações inibitórias de $\mathrm{IC}_{50}$ dos quimioterápicos doxorrubicina e gencitabina distribuídas nas diferentes fases do ciclo celular. Adquiridos em citometria de fluxo e analisados no programa WinMDI 2.8.

Figura 12 Gráfico de barras das médias \pm dp das células oriundas do homogenato da massa tumoral hepática tratadas com os quimioterápicos doxorrubicina, gencitabina, células-tronco mesenquimais e em associação a quimioterapia sistêmica, distribuídas nas diferentes fases do ciclo celular. Adquiridos em citometria de fluxo e analisados no programa WinMDI 2.8. 
Figura 13 Gráfico de barras das médias \pm dp da expressão dos marcadores (caspase 3, caspase 8, CD90, CD44, IL1-R, IL2-R e CD14) das células oriundas do homogenato da massa tumoral hepática tratadas com os quimioterápicos doxorrubicina, gencitabina, células-tronco mesenquimais e em associação a quimioterapia sistêmica.

Figura 14 Fotomicrografia demonstrando os aspectos citológicos das células-tronco mesenquimais da medula óssea de camundongos C57BL/6J.

Figura 15 Gráfico de barras das médias \pm dp da expressão dos marcadores para caracterização imunofenotípica das células-tronco mesenquimais da medula óssea de camundongos C57BL/6J (CD44, CD73, CD90, CD105 CD11b, CD45 e CD117).

Figura 16 Fotomicrografia de parênquima do fígado, pulmão, baço e rim dos animais portadores de carcinoma hepatocelular tratados com células-tronco mesenquimais.

Figura 17 Fotomicrografia de parênquima do fígado, pulmão, baço e rim dos animais portadores de carcinoma hepatocelular tratados com o quimioterápico doxorrubicina.

Figura 18 Fotomicrografia de parênquima do fígado, pulmão, baço e rim dos animais portadores de carcinoma hepatocelular tratados com o quimioterápico doxorrubicina em associação com células-tronco mesenquimais.

Figura 19 Fotomicrografia de parênquima do fígado, pulmão, baço e rim dos animais portadores de carcinoma hepatocelular tratados com o quimioterápico gencitabina.

Figura 20 Fotomicrografia de parênquima do fígado, pulmão, baço e rim dos animais portadores de carcinoma hepatocelular tratados com o quimioterápico gencitabina em associação com células-tronco mesenquimais. 


\section{INTRODUÇÃO}

\subsection{Carcinoma hepatocelular}

Devido ao custo cada vez maior do tratamento de doenças, juntamente com o difícil ambiente econômico, o interesse na promoção da saúde, como também o desenvolvimento de novas estratégias terapêuticas, está aumentando em todo o mundo. A Organização Mundial da Saúde define a promoção da saúde como o processo de capacitar as pessoas para aumentar o controle sobre sua saúde e seus determinantes (por exemplo, tabagismo, atividade física, dieta) e, assim, melhorar a sua saúde. As principais modalidades de tratamento do câncer são cirurgia, terapia sistêmica e radioterapia; estas podem ser utilizadas isoladamente ou combinadas. O tratamento ideal e o diagnóstico nos estágios iniciais da doença contribuíram para o declínio nas taxas de mortalidade por câncer de forma geral.

O carcinoma hepatocelular (CHC) é a neoplasia maligna primária mais comum do fígado, a quinta mais frequente e a terceira causa de morte por câncer no mundo. É um tumor epitelial derivado dos hepatócitos e seu parênquima é formado por células neoplásicas arranjadas em um padrão trabecular ou acinar em meio a pouca quantidade de estroma, por isso sua consistência é geralmente amolecida. (EL-SERAG, RUDOLPH, 2007).

Macroscopicamente pode ser classificado quanto a sua forma, tamanho ou quanto ao padrão de crescimento: massa unifocal usualmente grande; nódulos multifocais, amplamente distribuídos, de tamanho variável; um câncer difusamente infiltrante, permeando amplamente e às vezes comprometendo o fígado inteiro (PIMENTA, MASSABKI, 2010).

Os três padrões podem causar o aumento do fígado, especialmente os padrões maciços unifocais e multinodulares (KOJIRO, 1998). Os CHC tendem a ser mais pálidos que a substância hepática circundante e por vezes adquirem uma tonalidade verde quando compostos de hepatócitos bem diferenciados capazes de secretar bile. Todos os padrões de CHC têm forte propensão a invadir os canais vasculares. 
Metástases intra-hepáticas extensas seguem-se, e ocasionalmente longas massas invadem a veia porta e por ela tendem a crescer, com consequente oclusão da circulação portal, ou a veia cava inferior, estendendo-se até o coração direito (DI BISCEGLIE, CARITHERS, GORES, 1998).

Os carcinomas hepatocelulares variam de bem diferenciados a lesões indiferenciadas altamente anaplásicas. Nos tumores bem diferenciados e moderadamente bem diferenciados, células reconhecíveis como de origem hepatocítica estão dispostas em um padrão trabecular, lembrando placas de células hepáticas ou em um padrão acinoso pseudoglandular (CONTE, 2000). Nas formas pouco diferenciadas, as células tumorais podem assumir um aspecto pleomórfico com numerosas células gigantes anaplásicas, podendo tornar-se células pequenas e completamente indiferenciadas, ou assemelhar-se a um sarcoma de células fusiformes.

Uma variedade típica de CHC é o carcinoma fibrolamelar. Esse tumor ocorre geralmente em adultos jovens homens e mulheres com igual incidência, não tem associação com vírus da hepatite B (VHB) ou fatores de risco de cirrose, e na maioria das vezes tem melhor prognóstico.

Usualmente se apresenta como um tumor único, grande, duro, de aspecto cirrótico com faixas fibrosas correndo através dele. Ao exame microscópico, composto de células poligonais bem diferenciadas crescendo em ninhos ou cordões e separadas por lamelas paralelas de feixes colagenosos densos.

$\mathrm{O}$ CHC dissemina-se extensamente dentro do fígado por crescimento contíguo óbvio e pelo desenvolvimento de nódulos satélites. Metástases ocorrem principalmente por via hematogênica, especialmente para dentro do sistema da veia hepática. Entretanto, metástases hematogênicas, especialmente para o pulmão, tendem a ocorrer tardiamente na doença. Metástases linfonodais aos gânglios peri-hilares, peri-pancreáticos e paraaórticos acima e abaixo do diafragma são encontradas em menos da metade dos carcinomas hepatocelulares que se disseminam além do fígado (CONTE, 2000).

As opções de tratamento abrangem as terapias cirúrgicas (ressecção e transplante hepático) e não cirúrgicas (ablação percutânea, quimioembolização transarterial - TACE, radioembolização e terapia sistêmica) (MARTIN, 2009; BRUIX, SHERMAN, 2010). As terapias potencialmente curativas são ressecção cirúrgica, transplante hepático e terapias ablativas percutâneas, como radiofrequência e alcoolização. 
Os pacientes com CHC em estádio muito precoce (tumor com diâmetro inferior a $2 \mathrm{~cm}$ ) tratados por cirurgia alcançam sobrevida em 5 anos de aproximadamente $90 \%$ e, quando usados métodos de ablação percutânea, essa sobrevida é superior a $70 \%$ (TREMOSINI et al., 2010).

Para pacientes selecionados com doença irressecável, a opção cirúrgica mais viável é o transplante hepático. Tais casos compreendem, classicamente, os com tumor único com menos de que $5 \mathrm{~cm}$ de diâmetro ou até três tumores com até $3 \mathrm{~cm}$ cada, sem presença de invasão vascular ou metástases à distância. Nesses pacientes, incluídos nos denominados critérios de Milão, a sobrevida em 4 anos após o transplante hepático varia de $70 \%$ a $80 \%$ e a recorrência tumoral é aproximadamente de $10 \%$ (MAZZAFERRO et al., 1996). Entretanto, estima-se que apenas $10 \%$ a $30 \%$ daqueles com diagnóstico de CHC são elegíveis para tratamento curativo (LLOVET et al., 2003).

\subsubsection{Etiologia e fatores de risco}

O CHC é uma das poucas neoplasias com fatores de risco bem definidos. Há um desenvolvimento multifatorial e de múltiplas etapas do carcinoma hepatocelular. Dentre os vários fatores de risco, pode-se citar hepatopatia crônica por vírus $B, C$ e D, toxinas (álcool e aflatoxina), hepatopatias hereditárias metabólicas (hemocromatose hereditária, alfa- 1- antitripsina), hepatite autoimune, obesidade, esteato-hepatite não alcoólica. A associação entre cirrose e CHC está bem estabelecida, sendo presente em mais de $80 \%$ dos pacientes asiáticos e em 50\% dos pacientes europeus (BARBARA et al., 1996). A duração da hepatopatia contribui para o surgimento da doença, com aumento do risco após 20 anos de evolução. É raro o aparecimento de CHC em fígado normal, representando menos de 10\% dos casos (MACHADO, 2006). Tendo realizado o diagnóstico de CHC, têm-se em mãos algumas modalidades terapêuticas possíveis de serem realizadas. Estas podem ser cirúrgicas, e incluem a ressecção e o transplante, a ablação percutânea por radiofrequência ou alcoolização e a quimioterapia, sistêmica ou regional (CONTE, 2000). 


\subsection{Quimioterapia}

Atualmente, nenhum protocolo com resultados satisfatórios no tratamento de carcinomas hepáticos foi preconizado. A quimioterapia nestas situações se reserva no caso em que não são indicados os tratamentos padronizados como ressecção, injeção percutânea de etanol e/ou ácido acético e embolização arterial; portanto indicada para pacientes com metástases à distância e/ou com trombose tumoral portal e/ou reserva hepática funcional baixa, utilizando-se de novos fármacos via sistêmica (OKADA et al., 1998).

A estratégia de se aplicar a quimioterapia é amplamente aceita nestes casos (KEMENY, 2007), com o objetivo principal é reduzir o volume e o tamanho do tumor suficientemente para que estes pacientes inoperáveis se tornem aptos à cirurgia (BLENOIST, 2007).

Além do potencial de reduzir o tamanho da neoplasia, a quimioterapia também proporciona um importante papel, na observação do comportamento biológico do tumor. Se tornando de grande importância, pois assim evitaremos hepatectomias desnecessárias em pacientes que desenvolveram rapidamente metástases intra ou extra hepáticas. Além disso, a resposta à quimioterapia pré-operatória, fornece informações importantes sobre a sensibilidade do fármaco e as razões para se escolher um protocolo de tratamento pósoperatório. E por prever o prognóstico do paciente, devido à resposta a quimioterapia previamente aplicada (BLAZER et al., 2008).

Como em qualquer tecido humano, os tumores precisam de sangue para se desenvolver, obtendo através dele os nutrientes necessários para o seu crescimento. Portanto, há muitos anos foi idealizada a técnica de embolização, que tem por objetivo obstruir as artérias que levam o sangue para o tumor e assim causar a sua morte. Com intuito de melhorar a eficácia da embolização, foi idealizada a técnica da quimioembolização. $\mathrm{Na}$ qual se baseia na inoculação de um ou vários quimioterápicos através de um cateter posicionado seletivamente no órgão onde o tumor se encontra e posteriormente obstrução das artérias, a fim de evitar que o sangue continue irrigando o tumor. Desta forma consegue-se aumentar a concentração do quimioterápico no tumor e reduzir os efeitos colaterais sistêmicos. 
Há várias opções técnicas para a quimioembolização, mas recentemente tem surgido no mercado microesferas carregadoras de fármacos que tornaram o procedimento mais eficiente e seguro. Essas microesferas são embebidas previamente com um quimioterápico específico, como a gencitabina e doxorrubicina, e posteriormente são injetadas através de um cateter até ocluir os ramos tumorais (MARTíNES et al., 2008).

A doxorrubicina é um composto derivado das antraciclinas, isoladas na década de 1960 a partir da bactéria Streptomyces peucetius. As antraciclinas causam danos irreversíveis às células tumorais por se intercalarem nas fitas do DNA, inibir a síntese de proteínas e produzir espécies reativas de oxigênio, causando a morte celular. (BODLEY et al., 1989).

Estudos empregando a gencitabina como quimioterápico eletivo em neoplasias hepáticas demonstraram que mesmo não se obtendo a cura definitiva dos pacientes em estágios avançados da doença, se torna uma alternativa viável para se prolongar a qualidade de vida, obtendo-se assim resultados promissores (GALLARDO et al., 2001).

A utilização deste fármaco se baseia no efeito já demonstrado no tratamento de câncer de pâncreas. E devido ao pâncreas e a vesícula biliar compartilharem a mesma origem embriológica (GALLARDO et al., 2001).

\subsubsection{Hepatotoxicidades causadas pela quimioterapia}

Embora a terapia quimioterápica pré-operatória tenha inúmeras vantagens, o tratamento em si não deixa de causar uma crescente preocupação em relação aos seus efeitos colaterais, como por exemplo, o seu potencial hepatotóxico. Sendo os tipos mais observados: esteatose, esteatohepatite e lesões sinusoidais (KAHN et al., 2009; ZORZI, 2007).

Esteatose se refere ao acúmulo de lipídeos nos hepatócitos (HUBSCHER et al., 2006). O fígado exerce uma importante função na produção de lipoproteínas, como por exemplo, a lipoproteína de baixa densidade. Além de ser o local de maior armazenamento de glicogênio, qualquer desregulação de um desses processos pode acarretar na acumulação de lipídeos. Outros mecanismos incluem possíveis disfunções mitocondriais, levando a um aumento da oxidação das proteínas celulares. 
Nas fases posteriores da esteatose, está se associa a processos inflamatórios, o qual acarreta ao acúmulo de fibrose, levando a uma esteato-hepatite (FAREEL, 2006; ONG et al., 2007). Considerando que a esteatose e a esteato-hepatite interferem diretamente com a função dos hepatócitos, a obstrução sinusoidal acarreta numa síndrome de obstrução sinusoidal, anteriormente chamada de doença veno-oclusiva, levando a casos de hipertensão portal, ascite, hiperbilirrubinemia, e em casos mais graves, insuficiência hepática (HELMY, 2007).

\subsection{Fígado}

O fígado é o maior órgão visceral do corpo e está principalmente localizado no quadrante abdominal superior direito (região epigástrica), estendendo-se para o quadrante abdominal superior esquerdo. Anatomicamente, é dividido em lobos direito e esquerdo por fossas para a vesícula biliar e veia cava inferior. O suprimento arterial para o fígado inclui a artéria hepática direita, a partir da artéria hepática própria (um ramo da artéria hepática comum a partir do tronco celíaco); e a artéria hepática esquerda, a partir da artéria hepática própria (MATTOS, DANTAS-CORRÊA, 2010).

A drenagem venosa do baço, pâncreas, vesícula biliar e parte abdominal do trato gastrointestinal, com exceção da parte inferior do reto, ocorrem através do sistema portal de veias, que distribui o sangue a partir dessas estruturas para o fígado. Depois que o sangue passa através dos sinusoides hepáticos, ele atravessa progressivamente as veias maiores, até entrar nas veias hepáticas, que retornam o sangue venoso para a veia cava inferior imediatamente abaixo do diafragma (MATTOS, DANTAS-CORRÊA, 2010).

Vários tipos de células fenotipicamente distintas compõem o fígado. A célula hepática predominantemente é o hepatócito, uma célula epitelial responsável por regular o metabolismo intermediário, desintoxicar endo e xenobióticos, sintetizar proteínas e lipídeos, além de produzir e excretar a bile. O outro tipo de célula do fígado é o colangiócito, célula epitelial dos ductos biliares que modula o fluxo biliar (MATTOS, DANTAS-CORRÊA, 2010). 
Os hepatócitos encontram-se rodeados de capilares sinusoides e de vasos linfáticos. Isto faz com que o sangue flua livremente para as células e que os produtos celulares secretados no espaço perisinusoidal de Disse possam ser liberados no sangue ou nos vasos linfáticos.

As células de Kupfer são macrófagos fixos nas membranas dos sinusoides e podem ser encontradas em todo o fígado. À medida que o sangue vai atravessando o fígado, os eritrócitos envelhecidos ou danificados são fagocitados pelas células de Kupfer. Os hepatócitos metabolizam hormônios e fármacos, desintoxicando o sangue. Os hepatócitos produzem a bile e eletrólitos que drenam nos canalículos biliares, os quais levam ao ducto biliar (MATTOS; DANTAS-CORRÊA, 2010).

Em condições normais, o fígado contém aproximadamente $400 \mathrm{~mL}$ de sangue, o que representa cerca de $8 \%$ do volume total do sangue. Isso ilustra o aspecto de reserva de sangue do fígado. Dois fatores críticos param o funcionamento adequado do sistema são os fatos de a pressão sanguínea no fígado ser muito baixa, aproximadamente $1 \mathrm{mmHg}$, e de não haver obstrução do fluxo sanguíneo nos sinusoides hepáticos.

Isso permite que o sangue flua livremente através do fígado e fora dele para dentro da veia porta. Se houver obstrução do fluxo hepático (cirrose, hepatite, toxicidade) ou aumento da pressão venosa hepática (insuficiência cardíaca congestiva), o sangue retorna e a pressão sobe, causando hipertensão portal (MATTOS; DANTAS-CORRÊA, 2010).

\subsubsection{Estrutura morfofuncional hepática do camundongo}

O fígado do camundongo pesa aproximadamente $2 \mathrm{~g}$, abrange toda a região subdiafragmática e está dividido em quatro lobos principais: lobo caudal (dorsal e ventral em relação ao esôfago), lobo lateral direito (subdividido horizontalmente em anterior e posterior), lobo médio (subdividido em porções direita e esquerda) e o lobo lateral esquerdo (HEDRICH, BULLOCK, 2004). O lobo lateral direito apresenta um septo transverso que quase o corta. O lóbulo mediano se localiza mais ventralmente e é o lobo mais proeminente quando a cavidade abdominal é vista a partir de um aspecto ventral habitual. As suas duas asas piriformes ligadas por um istmo central estreito estão presentes sob o lobo mediano, e estas produzem o saco ventral da vesícula biliar. O lobo esquerdo é o maior e se torna um local frequente para coleta de amostra histológica. 
O lobo caudado é pequeno e apresenta dois segmentos distintos em formato auricular (MARTINZ, NEUHAUS, 2007).

As origens e os cursos dos grandes vasos no camundongo são semelhantes aos dos seres humanos. Cerca de $75 \%$ do sangue que entra no fígado é venoso, a partir do sistema da veia porta. Os $25 \%$ restantes de sangue arterial pelo sistema da artéria hepática. A anatomia da vasculatura hepática pode ser resumida como se segue: a artéria hepática comum é um ramo da artéria celíaca, que se ramifica da aorta abdominal; a veia hepática drena o fígado e adentra na veia cava inferior, perto do diafragma. A veia porta fornece sangue para o fígado a partir do intestino delgado, estômago, pâncreas e baço (MARTINZ, NEUHAUS, 2007).

\subsubsection{Regeneração hepática}

O termo regeneração é derivado do latim (regenerare $=$ gerar outra vez) e é definido como reconstituição da forma, da função e da massa do tecido lesado. Está presente, nesta forma conceitual, apenas nos répteis, pois os mamíferos não são capazes de recuperar a forma (MICHALANY, 2000). Apesar de biologicamente incorreto, o termo regeneração hepática é largamente utilizado, uma vez que a resposta induzida pelo dano tecidual hepático promove hiperplasia e hipertrofia compensatória do tecido remanescente até o restabelecimento da massa hepática primitiva. No entanto, os lóbulos ressecados não são recuperados (JESUS, WAITZBERG, CAMPOS, 2000; PALMES, SPIEGEL, 2004).

Este fato sugere que o crescimento induzido por perda de tecido (ressecção hepática) seja controlado principalmente por fatores fisiológicos. Tais fatores parecem ser precisos, uma vez que o crescimento é interrompido quando o fígado restabelece o seu peso original, ou então, uma vez que este seja capaz de executar o trabalho metabólico necessário às demandas funcionais do organismo (KOUNTOURAS, BOURA, LYGIDAKIS, 2001).

Talvez, mais notável que a capacidade dos hepatócitos se proliferarem é a sua capacidade de manter, simultaneamente a este processo, todas as funções essenciais para a homeostase. 
Essas funções incluem o metabolismo energético, armazenamento do glicogênio, síntese de glicose, fornecimento de ATP (adenosina trifosfato), metabolismo dos ácidos graxos, síntese de proteínas envolvidas na coagulação, secreção da bile, biodegradação de toxinas, entre centenas outras funções.

Poucas alterações nessas funções são percebidas quando restam apenas 30\% do órgão e que $90 \%$ das células deste órgão residual estão em processo de proliferação ou mitose ou ambos (ROSEN, PIMENTEL, 2005; MICHALOPOULOS, DEFRANCES, 1997; COURT et al, 2002).

Alguns fatores intrínsecos aos hepatócitos controlam a fisiologia do fígado normal. São eles o glicogênio, lipídeos, vitaminas, eletrólitos e as organelas microscópicas, como as mitocôndrias e o retículo endoplasmático (FRANCAVILLA et al.,1988). Avanços na compreensão da regeneração hepática têm sido obtidos com o advento da biologia molecular, cujas técnicas permitem o esclarecimento dos eventos que promovem e controlam a divisão celular (BLACK et al, 2004; RUDOLPH et al., 1999). Muitos fatores de crescimento e citocinas estão envolvidos na regeneração hepática. Eles podem ser divididos em mitogênicos, co-mitogênicos e inibidores. São considerados agentes mitogênicos: hormônio de crescimento; interleucina seis; fator de necrose tumoral alfa; substância estimuladora hepática e os fatores de crescimento do hepatócito, transformador alfa, de fibroblastos e epidérmico (BLACK et al, 2004; GORLA et al., 2001a; GORLA et al., 2001b).

Os fatores co-mitogênicos, que são capazes de potencializar a regeneração hepática, são: norepinefrina, vasopressina, angiotensinas, insulina, glucagon, prostaglandinas, estrógeno, testosterona e fibronectina (KWON et al., 1990; BIONDOSIMÕES et al., 2000). Se a integridade estrutural do fígado for danificada durante a agressão celular, a regeneração poderá ser desordenada e embora a massa hepática possa retornar ao seu tamanho normal, as relações estruturais da arquitetura hepática não serão restauradas e a regeneração será nodular (WIGHT, 1994), isto é, quando a necrose hepática é contínua, o fígado tentará regenerar sua massa funcional, mas o esforço regenerativo prolongado e a presença de dano na matriz extracelular normal do fígado frequentemente resultam em proliferação nodular do parênquima com distorção da arquitetura normal do fígado (CULLEN, MACLACHLAN, 2001). Essa nodularidade pode ser causada pela constrição das faixas de tecido fibroso (KELLY, 1993). 
Em todos os órgãos, a regeneração é um processo fisiológico controlado que é estimulado pela necessidade de maior quantidade de tecido funcional e é encerrado quando essa demanda aumentada é atingida (ROTH, 1995).

A regeneração hepática deve ser considerada uma resposta natural do fígado às agressões, mas há certas limitações nesse processo, que depende de que as áreas afetadas possuam adequado suprimento sanguíneo, drenagem livre de bile e arquitetura hepática normal, possuindo colunas de células em regeneração com orientação do arcabouço original de reticulina. Os hepatócitos proliferantes podem diferir dos hepatócitos normais em algumas de suas reações enzimáticas, mas há evidências de que eles sofram diferenciação e, dessa forma, podem substituir aqueles hepatócitos residuais danificados e restaurar o fígado normalmente se a agressão cessar (KELLY, 1993). Ainda não estão bem definidos quantos destes fatores são absolutamente necessários para a regeneração hepática. O que se sabe é que nenhum deles parece agir isoladamente e que maioria possui grande variedade de ações, alguns agem estimulando a proliferação, outros estimulam a divisão celular ou, dependendo de suas concentrações, podem inibir ou estimular o processo.

Durante a evolução, os vertebrados desenvolveram uma série de mecanismos celulares para a manutenção normal de homeostase para alcançar a recuperação do tecido após a lesão. Estes mecanismos variam entre as espécies e tipos de células, e estão divididos em três categorias: (A) a replicação de células existentes, (B) expansão e diferenciação e transdiferenciação de células-tronco / progenitoras, (C) reprogramação ou desdiferenciação de células a partir de um tipo de célula para outra. Em particular, o fígado de mamíferos tem várias características que o tornam interessante para o estudo do processo de regeneração; em condições de homeostase, o fígado tem uma baixa taxa de renovação celular, com células persistindo por semanas a meses sem se dividirem. Após uma lesão, por outro lado, o fígado pode produzir grande número de novas células. 
Este fenômeno tem importância clínica, como as maiorias dos pacientes que sofrem lesão hepática aguda recuperaram totalmente sua função, algumas questões podem ser aventadas: (1) quais os sinais de estimulação do tecido necessários para iniciar uma resposta regenerativa?; (2) tipo de resposta para conduzir a regeneração envolvendo as células regenerativas-tronco / progenitoras ou diferenciadas; (3) quais os mecanismos de controle da resposta regenerativa são a massa tecidual ou a função?; e (4) qual a explicação para falhas na regeneração e reparação tecidual de pacientes com lesão hepática crônica (STANGER, 2015).

\subsection{Terapia celular}

A terapia celular é definida como a abordagem terapêutica que visa à recuperação/regeneração de tecidos através do uso de diferentes tipos celulares ou grupo de células. Suas formas clássicas incluem o transplante de medula óssea (células-tronco hematopoiéticas) e a transfusão de sangue. O transplante de células diferenciadas (como o transplante de hepatócitos), indiferenciadas (células-tronco) e a engenharia de tecidos vêm crescendo como novas formas dessa terapia (ALLEN et al., 2005).

No campo da hepatologia, o transplante de hepatócitos tem sido realizado para uma série de situações, englobando desde doenças genéticas até falência hepática fulminante (FISCHER, STROM, 2006). Outra abordagem descrita é a utilização de células-tronco (ALLEN et al., 2005).

O número limitado de doadores de fígado para transplantes e a ausência de proliferação em cultura de hepatócitos, são os maiores fatores limitantes para as terapias que envolvam transplante hepático e hepatocitário, respectivamente. Essas características inviabilizam a utilização desses tratamentos em grande escala. Em contrapartida, progenitores hepáticos são altamente expansíveis in vitro e in vivo. Essas células são capazes de extensiva proliferação e subsequente diferenciação em células do ducto biliar e hepatócitos (MALHI et al., 2002). Sendo assim, a terapia com células-tronco oferece uma importe fonte de progenitores hepáticos para aplicações clínicas. A resposta do tecido hepático à terapia celular tem sido investigada nos últimos anos, com relatos de sucesso em vários modelos pré-clínicos de lesão hepática aguda e crônica como, por exemplo, os relatados por Di Campli em 2005 e Higashiyama em 2007. 
Durante a última década, modelos de investigação em animais e estudos clínicos sugerem que o transplante de hepatócitos pode ser útil para o tratamento de enfermidades metabólicas e como uma "ponte" para determinados pacientes com falência hepática fulminante à espera de um doador compatível (FISCHER, STROM, 2006). Essa abordagem requer mínima intervenção, mantém intacta a arquitetura hepática e permite restaurar a função deficiente ou alterada sem necessidade do transplante completo do órgão. Além disso, em teoria, ainda há a vantagem da criopreservação destas células, e de um doador pode fornecer células a mais de um receptor (DHAWAN et al., 2006). Baseado nessas informações, o uso de células-tronco (CT) parece ser uma alternativa promissora na terapia celular para doenças hepáticas (MALHI et al., 2002).

Por outro, lado o crescente desafio mundial para o tratamento da cirrose e do carcinoma hepatocelular, em decorrência do aumento do consumo excessivo de álcool, hepatite viral, obesidade e síndrome metabólica despertou o interesse em células-tronco semelhantes a células progenitoras do fígado, como uma alternativa potencial para terapia celular e engenharia de tecidos, como uma abordagem alternativa ao transplante do órgão inteiro. No entanto, as células progenitoras do fígado sempre proliferam nas doenças hepáticas crônicas com uma predisposição ao desenvolvimento de câncer; apesar de desempenhar papéis importantes na modulação da fibrose, na progressão da doença ou mesmo na iniciação do tumor (KÖHN-GAONE et al., 2016).

\subsection{Células-tronco}

O objetivo da Medicina regenerativa é desenvolver estratégias terapêuticas para a gestão de graves lesões ou doenças crônicas em pacientes cujos mecanismos regenerativos endógenos não conseguiram restaurar as funções alteradas. As célulastronco têm sido vista como a ferramenta importante para este fim, por atuarem por múltiplos mecanismos, envolvidos na reparação tecidual ou como agentes imunomoduladores.

A primeira população de células-tronco identificada foi a partir da medula óssea de camundongos adultos, por McCulloch e Til em 1960, e caracterizada posteriormente por Becker et al. (1963). 
Atualmente, existe um grande número de células-tronco pluripotentes isoladas e caracterizadas de diversos tecidos, sendo as células-tronco mesenquimais as mais estudadas devido a características de fácil isolamento e cultivo (CAPLAN, 1991; FRIEDENSTEIN, 1968; PITTENGER et al., 1999).

Outro tipo de célula-tronco estudada é a de origem embrionária. Descrita através de estudos celulares em teratomas de camundongos, na metade do século passado (LEWIS et al., 1964). Porém a caracterização destas células-tronco embrionárias de blastocistos só foi descrito no início dos anos 80. Tais células são isoladas de massas celulares internas de embriões em estágio de blastócito. Diferentemente dos zigotos, a célula-tronco embrionária perde a sua totipotência após sucessivas divisões celulares, sendo assim capaz de originar os tecidos das três camadas germinativas, a ectoderma, mesoderma e endoderma (ECKFELDT et al., 2005).

As células-tronco de origem fetal, recentemente descobertas, também se tornaram uma fonte alternativa de estudos. Sendo capazes de serem isoladas diretamente do feto ou de estruturas extra fetais de suporte (BOSSOLACO et al., 2006). Tendo como principais fontes de células-tronco fetais, o sangue do cordão umbilical, o próprio cordão umbilical, a membrana amniótica, o líquido amniótico e a placenta. Sendo a célula-tronco do sangue do cordão umbilical, a pioneira implantada em transplantes de medula (BROXMEIER et al., 1989).

A principal célula-tronco isolada de tecidos fetais é a CTM (célula-tronco mesenquimal), por apresentar potencial de expansão superior às células-tronco derivadas de tecidos adultos e por ser menos imunogênica, pois não expressa antígeno tipo II de superfície de leucócito humano (MIAO et al., 2006). No Brasil, a Lei Federal 11.105, de 24 de março de 2005, regulamentou as pesquisas nessa área e permitiu o uso de célulatronco embrionária para pesquisa e terapia. Essas células devem ser obtidas de embriões humanos produzidos por fertilização in vitro, devem ser embriões inviáveis e que tenham sido mantidos congelados por mais de três anos (TAKEUCHI; TANNURI, 2006). É obrigatória a obediência às seguintes condições: haver consentimento dos genitores, bem como a submissão prévia dos projetos à apreciação e aprovação dos respectivos comitês de ética em pesquisa. A lei veta a comercialização de material biológico para esse uso. Essas pesquisas poderão propor novas opções terapêuticas para várias doenças. 
No entanto, deve-se saber que ocorrerão debates éticos acerca da obtenção desse material biológico e a aplicabilidade clínica dessas novas modalidades terapêuticas ainda está muito distante para a maioria das doenças. Vale ressaltar que a clonagem humana foi proibida pela mesma lei (TAKEUCHI; TANNURI, 2006).

Devido ao tema ser de ampla divergência, diversos autores descreveram as suas opiniões e entraram no seguinte consenso a respeito do conceito de células-tronco. Definidas classicamente com base em suas três principais características como a capacidade de auto renovação, ou a habilidade de gerar no mínimo uma célula filha com características similares as da célula mãe, a capacidade de uma única célula se diferenciar em diversas linhagens celulares e a possibilidade de reconstituir funcionalmente, in vivo, um tecido lesionado (TAKEUCHI; TANNURI, 2006). A partir do avanço da ciência, vários outros tipos de células foram isoladas e definidas como células-tronco, como por exemplo, as células-tronco mesenquimais (JIANG et al., 2002). Encontrada abundantemente nas células progenitoras derivadas do período embrionário, as quais dão origens a linhagens neuroectodermal, endodermal e mesodermal e em células progenitoras neuronais. (WIESE et al., 2004). Sendo expressa também em células do folículo piloso e em células de origem fetal como as da medula óssea de fetos humanos (LI et al., 2003).

A medula óssea é composta por dois sistemas de células-tronco: o sistema hematopoiético e o estromal, diferentemente do que ocorrem nos demais órgãos (BIANCO et al., 2006). Por já ter sido demonstrada in vitro, sua habilidade de diferenciação em diversos tecidos, sua possível ação de reparo tecidual e por ter um papel importante na imunomodulação, tais células adquiriram grande destaque no ramo de pesquisas científicas (CAPLAN et al., 1991, 2005).

A questão mais intrigante dos pesquisadores é se o suposto potencial de divisão, por um determinado período de tempo, das células-tronco cultivadas poderia levar ao acúmulo de alterações genéticas e epigenéticas, resultando em um processo neoplásico. Daí a importância do papel da citogenética humana no controle e monitoramento das células-tronco cultivadas, que serão utilizadas na terapia em seres humanos (CATALINA et al., 2007). 
Alterações cromossômicas estruturais, tais como deleções, translocações e inversões, representam um mecanismo importante pelo qual as células cancerígenas desenvolvem-se gradualmente, uma vez que estas alterações cromossômicas podem levar a uma expressão anormal de muitos genes, podendo desencadear assim o processo neoplásico (DUESBERG et al., 2005).

Situação similar tem sido observada em células-tronco embrionárias humanas cultivadas. Embora alterações em um grande número de genes pareçam raras nas célulastronco embrionárias cultivadas, linhagens destas células-tronco, derivadas independentemente em diferentes laboratórios do mundo, têm evidenciado as mesmas alterações cromossômicas recorrentes, das quais as mais frequentes são as trissomias dos cromossomos 12 e 17 (HOFFMAN, CARPENTER, 2005; MEISNER, JOHNSON, 2008). A poliploidia representa um estágio no qual as células possuem mais do que dois conjuntos cromossômicos, e estas células poliploides podem se originar após o estresse celular, envelhecimento e em várias doenças (COMAI, 2005; STORCHOVA, PELLMAN, 2004). Evidências sugerem que as células poliploides são geneticamente instáveis e podem agir como um passo intermediário para a tumorigênese. Esta hipótese pode explicar por que muitos tipos de câncer contêm consideráveis alterações no número dos cromossomos e raramente apresentam ganho ou perda de um único cromossomo (GANEM et al., 2007).

Apesar da grande regenerativa do fígado a partir das células-tronco, o fígado apresenta normalmente baixa taxa de proliferação e a constatação de que a maioria dos hepatócitos possui a capacidade de sintetizar DNA após uma hepatectomia parcial, se tornou uma alternativa para o modelo de terapia com células-tronco. Esta alternativa se deu na forma de hipótese de células-tronco facultativas, um modelo em que as célulastronco não são utilizadas durante a homeostase, mas sim em decorrência da presença de injúrias teciduais persistentes (ZIPORI, 2004).

Em meados da década de 1950, Farber e Popper et al, descreveram o surgimento de pequenas células em forma oval em resposta a liberação de hepatotoxinas. Estas células surgem em muitos ou a maioria dos modelos experimentais de hepatocarcinogênese ou lesão induzida por toxina e estas forma caracterizadas como, hepatócitos ductais, células hepatobiliares intermediárias e proliferação ductal atípica. Células ovais são caracterizadas por uma forma oval, de tamanho pequeno, citoplasma escasso, e pequeno lúmen (LEE et al., 2006). 
A medicina regenerativa e a terapia celular representam enfoques emergentes no conhecimento da biologia das células-tronco. Se o papel das células-tronco na manutenção da homeostase tecidual está claro, sua participação para o desenvolvimento do câncer ainda requer bastante investigação, e a presente proposta ressalta, como foco principal, a pesquisa nesta área do conhecimento. Portanto, para um tumor crescer, tornarse metastático e sofrer recorrência após intervenção terapêutica, a presença de subpopulações de células com grande capacidade de auto renovação, assim como as células-tronco, representaria um direcionamento biológico comum.

A hipótese das células-tronco promoverem o desenvolvimento do câncer se baseia no fato destas células serem particularmente alvos suscetíveis de carcinogênese e, consequentemente, dar origem a diferentes tipos de câncer. A utilização das célulastronco humanas cultivadas em laboratório necessita da garantia de um controle exaustivo e rigoroso com respeito à qualidade, confiabilidade e rastreabilidade. A instabilidade genética, caracterizada pelas anormalidades cromossômicas, representa uma importante lacuna em estudos básicos visando aplicações terapêuticas, utilizando linhagens de células-tronco cultivadas (CATALINA et al., 2007). 


\section{JUSTIFICATIVA}

Nosso grupo demonstrou no modelo de osteossarcoma canino, os efeitos inibitórios da terapia celular no crescimento e diferenciação das células-tronco da medula óssea. Tornando-se uma alternativa eficaz no tratamento de osteossarcomas caninos, inibindo a capacidade de proliferação por mecanismos de apoptose e supressão do crescimento do tumor mediado pela expressão da p53 (RICI et al., 2012). Em virtude de uma lesão neste órgão, a capacidade regenerativa do hepatócito é suficientemente capaz de restabelecer o parênquima como um todo. Entretanto, a capacidade regenerativa por meio de células maduras altamente diferenciadas é limitada. Contudo, hoje está bem estabelecido que células precursoras participem do processo regenerativo hepático. A medicina regenerativa e a terapia celular representam enfoques emergentes no conhecimento da biologia das células-tronco, responsáveis pela manutenção da homeostase tecidual. Neste sentido o presente trabalho visa a avaliar os processos de atenuação dos efeitos deletérios dos agentes quimioterápicos associados à terapia celular com célula-tronco. 


\section{OBJETIVOS}

$\checkmark$ Determinar o potencial regenerativo e imunomodulador de células-tronco mesenquimais da medula óssea no modelo de carcinoma hepatocelular murino associadas ou não ao tratamento quimioterápico para validação em estudos em humanos.

Avaliar os efeitos da terapia celular com células-tronco associada aos quimioterápicos gencitabina e doxorrubicina no modelo murino de carcinoma hepatocelular.

Abordar os aspectos da atenuação dos efeitos colaterais dos agentes quimioterápicos associados à terapia celular com células-tronco mesenquimais da medula óssea. 


\section{IMPACTOS ESPERADOS}

Contribuir para o conhecimento por meio do desenvolvimento e adaptação tecnológica voltada à quimioterapia aplicada ao carcinoma hepatocelular, abrir perspectivas de transferência para área quimioterápica, e sua consequente aplicação e utilização, estabelecer e incrementar o treinamento de pesquisadores envolvidos no processo, bem como o desenvolvimento de habilidades específicas, desenvolver uma nova forma de tratamento do câncer, que possui grande impacto no cenário nacional e internacional, criar um método mais eficiente e específico de tratamento e inibição do carcinoma hepatocelular e outras linhagens de células tumorais.

A equipe poderá sinalizar o desenvolvimento e/ou adequação de tecnologia aplicada à saúde humana e animal. Desenvolvimento de tecnologia específica visando maximizar a indução da citotoxicidade em células tumorais.

Com o sucesso deste estudo e futuramente o estabelecimento de um processo adequado a humanos, haveria diminuição de gastos públicos com tratamentos e medicamentos mais dispendiosos e menos eficazes, com melhora significativa no tempo e qualidade de vida destes pacientes. 


\section{MATERIAIS E MÉTODOS}

\subsection{Modelo experimental ortotópico de carcinoma hepatocelular em camundongos}

Neste estudo foram utilizados 70 camundongos isogênicos, Mus musculus, machos, da linhagem C57BL/6J, pesando entre 20 - 40g, que foram mantidos em gaiolas de polietileno com tampa de aço inox. Os animais foram obtidos do Biotério Central do Instituto Butantan e mantidos no biotério de experimentação animal do laboratório de Bioquímica e Biofísica, localizado no Prédio Novo. A ração granulada e água foram oferecidas ad libitum. A temperatura ambiente foi mantida entre 20 e $25^{\circ} \mathrm{C}$, a umidade relativa e um baixo nível de ruído foram mantidos dentro das condições ideais. O foto período foi controlado para prover luz das 06h00min às 18h00min horas (Certificado Comissão de Ética $\left.{ }^{\circ} 1002 / 13\right)$.

O modelo de implantação do carcinoma hepatocelular murino foi realizado pela inoculação intra-hepática das células tumorais murinas (Hepa1c1c7) a uma concentração de $10^{6}$ células tumorais. Os camundongos foram anestesiados, via intraperitonial, com $100 \mathrm{mg} / \mathrm{kg}$ de cetamina e $10 \mathrm{mg} / \mathrm{kg}$ de xilazina. Atingindo o período de latência em dois a três minutos. Em seguida, foram submetidos à contenção manual. As células tumorais foram lentamente inoculadas no lobo superior esquerdo do fígado, em um ângulo de 30 graus, através de uma agulha hipodérmica $(13 \times 0,30 \mathrm{~mm})$. Após a inoculação, um pequeno pedaço de gaze estéril foi pressionado no local da injeção, durante um minuto para evitar sangramento.

Após a implantação das células tumorais, os animais foram mantidos em gaiolas aquecidas, observados durante 1-2 horas, e, posteriormente, devolvidos ao biotério após a total recuperação da anestesia. Os animais foram divididos em diferentes grupos de tratamento, contabilizando cinco grupos no total. 
- GRUPO CONTROLE (N=10 ANIMAIS)1: SEM TRATAMENTO.

Semanalmente, contabilizando a partir do dia 0 de inoculação, dois camundongos foram submetidos à eutanásia através do deslocamento cervical, para avaliação do tempo de aparição do tumor e crescimento pela mensuração do comprimento e largura, assim como, foram coletados a massa tumoral e órgãos internos, para análise histológica, avaliação do ciclo celular e expressão de marcadores. Após a determinação do tempo de implantação do tumor, todos os animais deste grupo foram submetidos à eutanásia, e posteriormente realizadas as análises descritas acima.

- GRUPO EXPERIMENTAL 01 (N = 10 ANIMAIS): CÉLULAS-TRONCO MESENQUIMAIS DA MEDULA ÓSSEA (CTMO).

Após ser determinado o tempo de implantação do tumor, inoculou-se uma vez por semana, durante um mês, células-tronco mesenquimais, na concentração de $1 \times 10^{6}$, através da via endovenosa, utilizando seringa de $1 \mathrm{~mL}$ e agulha hipodérmica $(13 \times 0,30$ $\mathrm{mm}$ ). Semanalmente avaliou-se o peso dos animais e hematologia. Os animais receberam um total de quatro doses de células-tronco mesenquimais administradas por via intravenosa. Após o período de tratamento, os animais foram eutanasiados e posteriormente coletados os órgãos internos (pulmão, baço, rins e fígado). Os fígados foram macerados e mantidos em fixadores para posterior avaliação do ciclo celular, expressão de marcadores e análise histológica.

- $\quad$ GRUPO EXPERIMENTAL 02 (N = 10 ANIMAIS): DOXORRUBICINA (QT1). Adotou-se o mesmo procedimento do grupo experimental um, diferindo apenas o protocolo terapêutico e via de administração, o qual foi inoculado por via intraperitoneal em uma concentração 2,4 mg / $\mathrm{kg}(4.4 \mu \mathrm{M})$ de doxorrubicina, a cada dois dias, durante duas semanas.

- $\quad$ GRUPO EXPERIMENTAL 03 (N = 10 ANIMAIS): GENCITABINA (QT2).

Adotou-se o mesmo procedimento do grupo experimental um, diferindo apenas o protocolo terapêutico e via de administração, o qual foi inoculado por via intraperitoneal em uma concentração $40 \mathrm{mg} / \mathrm{kg}(130 \mu \mathrm{M})$ de gencitabina, a cada dois dias, durante duas semanas. 
- GRUPO EXPERIMENTAL 04 ( $\mathrm{N}=15$ ANIMAIS): DOXORRUBICINA E CÉLULAS-TRONCO MESENQUIMAIS DA MEDULA ÓSSEA (QT1 + CTMO).

Adotou-se o mesmo procedimento do grupo experimental um, diferindo apenas o protocolo terapêutico e via de administração, o qual foi inoculado por via intraperitoneal em uma concentração 2,4 mg / $\mathrm{kg}(4.4 \mu \mathrm{M})$ de doxorrubicina, a cada dois dias, durante duas semanas, em associação a administração das células-tronco mesenquimais como descrito acima.

- GRUPO EXPERIMENTAL 05 ( $\mathrm{N}=15$ ANIMAIS): GENCITABINA E CÉLULAS-TRONCO MESENQUIMAIS DA MEDULA ÓSSEA (QT2 + CTMO).

Adotou-se o mesmo procedimento do grupo experimental um, diferindo apenas o protocolo terapêutico e via de administração, sendo inoculado por via intraperitoneal na concentração $40 \mathrm{mg} / \mathrm{kg}(130 \mu \mathrm{M})$ de gencitabina, a cada dois dias, durante duas semanas, em associação a administração das células-tronco mesenquimais, como descrito acima.

\subsection{Análise do perfil hematológico}

O perfil hematológico dos camundongos nos diferentes grupos de tratamento foi determinado nos dia 7, 14, 21 e 28 após a inoculação das células tumorais. Aproximadamente $20 \mathrm{uL}$ de sangue foi recolhido dos camundongos a partir da punção retro-orbital através de tubos capilares heparinizados. Os glóbulos brancos, glóbulos vermelhos e plaquetas foram contados manualmente usando uma câmara de Neubauer. Para a contagem do número de reticulócitos foram utilizados $20 \mu \mathrm{L}$ de sangue adicionados à $20 \mu \mathrm{L}$ do corante azul de cresil brilhante. Após este procedimento, as soluções resultantes foram incubadas em banho maria à $37^{\circ} \mathrm{C}$ por 20 minutos. Em seguida foram realizados os esfregaços e as leituras realizadas em microscópio óptico com objetiva de imersão. Os valores foram expressos em porcentagem média por campo. 


\subsection{Avaliação da redução do volume do tumor hepático}

Após o período de tratamento, os animais foram eutanasiados e em seguida obtidas as massas hepáticas para avaliação da redução do volume no tumor e a obtenção de diferenças entre os grupos de tratamento (QT1, QT2, CTMO, QT1 + CTMO e QT2 + CTMO) em relação ao grupo controle tumoral. Através da diferença obtida pela subtração do volume tumoral, expresso em percentagem, do grupo controle tumoral em comparação aos diferentes grupos de tratamento.

\subsection{Cultura celular (Hepa1c1c7)}

As células da linhagem de carcinoma hepatocelular murino Hepa1c1c7 foram cedidas gentilmente pela Prof ${ }^{\mathrm{a}}$. Dr ${ }^{\mathrm{a}}$. Christiane Pienna Soares, Laboratório de Análises Clínicas-UNESP, Araraquara, São Paulo. As células foram cultivadas em frascos de cultura de $75 \mathrm{~cm}^{2}$ em meio de cultura ( $\alpha$ MEM) suplementado com $10 \%$ de soro fetal bovino (SFB), 10ml/L de solução de penicilina G-estreptomicina-fungizona (1:1:1), e 2,2g de $\mathrm{NaHCO}_{3}$, a $37^{\circ} \mathrm{C}$, numa atmosfera umidificada de $5 \%$ de $\mathrm{CO}_{2}$.

Antes das células atingirem confluência, as mesmas foram subcultivadas para ampliação e congelamento (meio completo contendo $10 \%$ de dimetilsulfóxido), e mantidas em nitrogênio líquido. As suspensões celulares utilizadas para inoculação nos animais foram obtidas após o tratamento dos frascos de cultura com tripsina $0,2 \%$ por 5 minutos e inativação com $10 \%$ de SFB. As células desprendidas foram centrifugadas, ressuspensas em meio de cultura e a concentração celular ajustada por contagem em câmara de Neubauer. A viabilidade celular foi avaliada simultaneamente usando a exclusão de teste de azul de tripan. Em geral, obteve-se mais do que $98 \%$ de células viáveis em cada isolamento. 


\subsection{Determinação da atividade citotóxica dos quimioterápicos doxorrubicina e gencitabina em células de carcinoma hepatocelular murino (Hepa1c1c7) pelo método colorimétrico MTT.}

Após descolamento por tripsinização e centrifugação, as células de carcinoma hepatocelular murino (Hepa1c1c7) foram plaqueadas a uma concentração de $10^{5}$ células/ml em placas de 96 poços. As células foram tratadas após 24 horas de adesão e confluência com diferentes concentrações dos quimioterápicos doxorrubicina $(0,05 \mu \mathrm{M}$ a $250 \mu \mathrm{M})$ e gencitabina (1,46 $\mu \mathrm{M}$ a 7,000 $\mu \mathrm{M})$, ambos diluídos em solução salina.

A viabilidade celular foi determinada pelo método colorimétrico MTT [brometo de 3- (4,5-dimetiltiazol-2-il) -2,5-difeniltetrazólio] (MOSMANN, 1983).

O sobrenadante da cultura celular foi removido e armazenado num congelador a $20{ }^{\circ} \mathrm{C}$ para análise da peroxidação de lipídeos da membrana celular. Foram adicionados $20 \mu \mathrm{l}$ de MTT ( $5 \mathrm{mg} / \mathrm{ml}$ ) às células e estas foram incubadas durante três horas em estufa contendo $5 \%$ de $\mathrm{CO}_{2}$ a $37^{\circ} \mathrm{C}$.

Após este período, o meio foi removido e adicionou-se $100 \mathrm{~mL}$ de metanol absoluto para dissolver todos os cristais de formazan formados e precipitados. A medição de absorbância foi realizada num leitor de ELISA (Titertek Multiskan) num comprimento de onda de $540 \mathrm{~nm}$. Foi avaliada por esta metodologia a toxicidade em condições experimentais de tratamento, assim obteve-se a determinação matemática da equação da reta, a concentração inibidora de $50 \%\left(\mathrm{IC}_{50}\right)$ e o coeficiente de correlação $\left(\mathrm{r}^{2}\right)$. Após o período de incubação com os compostos as células foram foto documentadas em aumento de 40 vezes no microscópio óptico de inversão mais o aumento de três vezes da aquisição digitalizada em pixels em câmera digital. 


\subsection{Determinação da peroxidação de lipídeos da membrana celular (TBARS)}

A quantificação da peroxidação de lipídeos é baseada na formação de substâncias reativas ao ácido tiobarbitúrico (TBARS), predominantemente o malondialdeído (MDA), que ocorre após a lipoperoxidação das membranas celulares. Estas substâncias produzem uma coloração característica que é medida espectrofotometricamente. Os sobrenadantes das culturas celulares geradas da mesma forma como descrito no ensaio de citotoxicidade de MTT foram recolhidos e mantidos em refrigeração $-20^{\circ} \mathrm{C}$ até à análise de peroxidação lipídica. As amostras foram descongeladas à temperatura ambiente, foi adicionado em um microtubo $50 \mu \mathrm{L}$ da referida amostra juntamente com $250 \mu \mathrm{L}$ de ácido tricloroacético $20 \%$ de TCA (ácido tricloroacético a 20 g em $100 \mathrm{ml}$ de água ultrapura). Em outro microtubo, $50 \mu \mathrm{l}$ de uma mesma amostra foram adicionadas $250 \mu \mathrm{l}$ de ácido tiobarbitúrico - 0,86\% de TBA (ácido tiobarbitúrico 0,86 g em $100 \mathrm{~mL}$ de TCA a 20\%). Os microtubos foram colocados num banho de água $\left(100^{\circ} \mathrm{C}\right)$, durante 20 minutos, seguido por resfriamento a $0^{\circ} \mathrm{C}$ durante 20 minutos. Os microtubos foram centrifugados a $8000 \mathrm{rpm}$ durante quatro minutos e os sobrenadantes foram usados para a quantificação de TBARS. A leitura foi realizada a um comprimento de onda de $535 \mathrm{~nm}$ num espectrofotómetro.

Os valores de cálculo da peroxidação lipídica foram realizados após deduzir o valor do fundo correspondente de cada intervalo, subtraindo a absorbância média da série de TBA da série TCA e dividindo-se pelo coeficiente de extinção molar de malondialdeído (MDA), que é 0,0312. Os resultados foram expressos como nanomoles de MDA por mililitro (nM MDA/mL).

\subsection{Análises das fases do ciclo celular "in vitro" por citometria de fluxo}

Após descolamento por tripsinização e centrifugação, as células de carcinoma hepatocelular murino (Hepa1c1c7) foram plaqueadas a uma concentração de $5 \times 10^{5}$ células / $\mathrm{mL}$ em placas de seis poços. Após adesão e confluência as células foram tratadas por 24 horas com as concentrações de $\mathrm{IC}_{50}$ dos quimioterápicos doxorrubicina $(1,85 \mu \mathrm{M})$ e gencitabina $(20,8 \mu \mathrm{M})$, ambos diluídos em solução salina. 
Em seguida, as células foram centrifugadas por dez minutos (1400 rpm), e o pellet ressuspendido em $1 \mathrm{~mL}$ de "Cold GM" (glicose 6,1 mM; NaCl 137 mM; KCl 4,4 mM; $14 \mathrm{Na}_{2} \mathrm{HPO}_{4}$ 1,5 mM; $\mathrm{KH}_{2} \mathrm{PO}_{4}$ 0,9 mM; EDTA 0,5 mM). Em seguida, adicionou-se lentamente etanol absoluto $\left(4^{\circ} \mathrm{C}\right)$, agitando-se lentamente. As células foram fixadas por 30 minutos. Após este período, as células foram centrifugadas, lavadas com PBS contendo 5 mM EDTA (Sigma Aldrich, EUA) e ressuspensas em uma solução contendo PBS (com 5 mM EDTA), $18 \mu \mathrm{g} / \mathrm{mL}$ de iodeto de propídeo (PI) (Sigma Aldrich, EUA) e $0,3 \mathrm{mg} / \mathrm{mL}$ de RNase-A. As células foram mantidas a temperatura ambiente durante uma hora, no escuro. A leitura foi realizada por citometria (FASC Calibur BD, EUA), no canal FL2-H. Os resultados obtidos demonstraram em qual período do ciclo celular as células se encontram (sub-G1, G0/G1, S ou G2/M), os dados foram apresentados em porcentagem.

\subsection{Análises das fases do ciclo celular “in vivo" por citometria de fluxo}

As células tumorais dos nódulos do carcinoma hepatocelular presentes no parênquima hepático foram isoladas do homogenato da massa tumoral por meio da filtração celular por membranas com poros de $70 \mu \mathrm{M}$ (Falcon, USA). Posteriormente, as células foram centrifugadas por 10 minutos (1400 rpm), e o botão celular ressuspendido em $1 \mathrm{~mL}$ de "Tampão - Cold GM", composto por glicose 6,1 mM; $\mathrm{NaCl} 137 \mathrm{mM}$; KCl 4,4 mM; $14 \mathrm{Na}_{2} \mathrm{HPO}_{4}$ 1,5 mM; $\mathrm{KH}_{2} \mathrm{PO}_{4}$ 0,9 mM; EDTA 0,5 mM. Em seguida, adicionouse lentamente etanol absoluto $\left(4^{\circ} \mathrm{C}\right)$, agitando-se lentamente. As células foram fixadas por 30 minutos, centrifugadas e lavadas com PBS contendo 5 mM EDTA (Sigma Aldrich, EUA) e ressuspensas em PBS contendo com $5 \mathrm{mM}$ EDTA, $18 \mu \mathrm{g} / \mathrm{mL}$ de iodeto de propídeo (PI) (Sigma Aldrich, EUA) e $0,3 \mathrm{mg} / \mathrm{mL}$ de RNase-A. As células foram mantidas a temperatura ambiente durante uma hora, no escuro. A leitura foi realizada no citômetro FACScalibur (BD, EUA), no canal de fluorescência FL2-H. Os resultados forma adquiridos no programa Cell-Quest e analisados no programa ModFit LT (BD, EUA). 


\subsection{Análise da expressão de marcadores “in vivo” por citometria de fluxo}

As células tumorais de carcinoma hepatocelular isoladas da massa tumoral hepática por meio da filtração celular por membranas com poros de $70 \mu \mathrm{m}$ (Falcon, USA), foram fixadas em tampão FACs-Flow com paraformaldeído $(2,5 \%)$ por uma hora e as membranas permeabilizadas com Triton X-100 (0,1\%), por 30 minutos, a $4{ }^{\circ} \mathrm{C}$. As suspensões celulares foram lavadas e ressuspendidas em tampão FACs-Flow. Em seguida, adicionou-se $1 \mu \mathrm{g}$ do anticorpo primário específico para os seguintes marcadores: Caspase 3 - Santa Cruz Biotechnology sc-136219; Caspase 8 - Santa Cruz Biotechnology sc-5263; CD90 R\&D System IgG2A clone \# 778053, CD44 Abcam ab119348, clone 1M7.8.1; IL1-R Santa Cruz Biotechnology clone H-153 sc-7884; IL2-R Santa Cruz Biotechnology, clone H-133 sc-7896 e CD14 Santa Cruz Biotechnology clone TUK4 sc-19588).

Após uma hora de incubação, as células foram centrifugadas $1500 \mathrm{rpm}$ por dez minutos e adicionou-se o anticorpo secundário marcado, na diluição de 1/100 em tampão FACS Flow específicos para cada marcador: o anticorpo anti-IgG de camundongo (Alexa-Fluor ${ }^{\circledR}$ 488, Z25002- Invitrogen; Ficoeritrina- PE, Invitrogen; isotiocianato de fluoresceína - FITC, Invitrogen) com albumina do soro bovino (BSA) 0,2\%, por uma hora, a $4^{\circ} \mathrm{C}$ protegidos da luz. Após a ligação específica dos anticorpos, as células foram lavadas e ressuspendidas em $200 \mu \mathrm{L}$ de tampão FACS-Flow.

A aquisição foi realizada em citômetro de fluxo FACScalibur (BD FACSCaliburTM ) utilizando o programa "Cell Quest", com aquisição de 10.000 eventos, tendo como parâmetros FSC (tamanho) e SSC (granulosidade/complexidade) em escala logarítmica e/ou linear e as intensidades de fluorescência determinadas no canal FL1FITC (verde) /FL2 - PE (vermelho), que detectam a fluorescência da interação marcador/anticorpo conjugado a PE e/ou FITC. 


\subsection{Cultura de células-tronco mesenquimais da medula óssea (CTMO)}

O isolamento de células de medula óssea foi realizado pela coleta da medula óssea dos camundongos C57BL/6J, a partir da dissecção do membro pélvico, com base no fémur, este foi inicialmente desarticulado de sua inserção ao osso coxal, a fim de melhor isolamento e exposição. Subsequentemente, foram removidos a pele e os músculos, as epífises proximais e distais com o auxílio de uma tesoura. Após este procedimento, o canal medular foi lavado com meio de cultura DMEM (Dulbecco's Modified Eagle Medium) e estreptomicina/penicilina, 1\%, utilizando uma seringa de $1 \mathrm{ml}$ e uma agulha $25 \times 7$. Após o cultivo foi realizado o isolamento de células progenitoras da medula óssea com morfologia de células aderentes semelhantes à fibroblastos in vitro. A partir do método de separação por centrifugação em Ficoll-Hypaque - 1073, um aspirado de medula óssea foi plaqueado em meio DMEM (Dulbecco's Modified Eagle Medium) suplementado com $10 \%$ de soro fetal bovino (SFB), 10ml/L de solução de penicilina Gestreptomicina-fungizona (1:1:1), e 2,2g de $\mathrm{NaHCO}_{3}$, a $37^{\circ} \mathrm{C}$, numa atmosfera umidificada de $5 \%$ de $\mathrm{CO}_{2}$. Após 72 horas, todo o meio de cultura foi substituído a fim de remover as células não aderentes. Antes das células atingirem confluência, as mesmas foram subcultivadas para ampliação e congelamento (meio completo contendo $10 \%$ de dimetilsulfóxido), mantidas em nitrogênio líquido. As células restantes foram cultivadas em câmara úmida e o meio de cultura foi trocado a cada quatro dias, durante 12 dias até atingirem confluência de cerca de $80 \%$. A suspensão de células utilizada para os animais de inoculação foram obtidos após o tratamento dos frascos de cultura com tripsina a $0,2 \%$ durante cinco minutos e inativação com $10 \%$ de SFB. As células isoladas foram centrifugadas, ressuspensas em meio de cultura de células e concentração ajustada por contagem em câmara de Neubauer. 


\subsubsection{Caracterização imunofenotípica das células-tronco mesenquimais da medula óssea de camundongos C57BL/6J}

As células progenitoras da medula óssea de camundongos C57BL/6J isoladas a partir do método de separação por centrifugação em Ficoll-Hypaque - 1073 foram submetidos à técnica de citometria de fluxo com os seguintes anticorpos monoclonais: CD73 (ecto 5'-nucleotidase, envolvida na diferenciação linfoide), CD90 [glicofosfatidilinositol Santa Cruz Biotechnology clone GPI/V-20 -sc-14682) ancorado na superfície celular, possuindo um domínio semelhante a cadeia leve da imunoglobulina - Thy-1], CD44 (receptor para o ácido hialurónico - Santa Cruz Biotechnology clone TUK4 sc-19588), CD105 (endoglina - Abcam clone SN6, ab11414), CD11b (membro da família da integrina que se liga ao CD18 para formar o heterodímero CR3; EBioscence cn 9012-0118-025- clone: ICRF44), CD31 (membro da superfamília de imunoglobulina, envolvidos na transmigração de leucócitos, a angiogênese, e a ativação de integrina), CD34 (membro de uma família de proteínas transmembranas sialomucinas expressas em células hematopoéticas e tecido vascular - Abcam ab28364), CD45 (antígeno comum de leucócitos é uma glicoproteína transmembranar do receptor do tipo proteína tirosina fosfatase - Santa Cruz Biotechnology clone F10-89-4 sc-52490) e o marcador CD117 (tipo de receptor de tirosina quinase III, que se liga ao fator de células-tronco - Santa Cruz Biotechnology sc-19983). A linhagem celular utilizada neste estudo se encontra disponível no banco de células sob a responsabilidade do Prof. Dr. Durvanei Augusto Maria.

\subsection{Análise histopatológica}

Fragmentos do lóbulo hepático médio e de órgãos internos de diferentes grupos animais foram fixados em formalina tamponada 10\%, processados e corados por Hematoxilina e Eosina (HE). As lâminas foram submetidas à revisão microscópicas por dois observadores a fim de avaliar características histopatológicas como infiltrado inflamatório, neoplásico e análise da arquitetura tecidual. 


\subsection{Análises estatísticas}

Após a obtenção dos valores individuais de cada linhagem celular tratada e controle, os resultados foram tabelados e analisados no programa Graphpad, Version 5.0 e InstatPad Prism Version 4.0. A análise dos dados será realizada pelas comparações de dois ou mais grupos com distribuição não paramétrica utilizando-se a análise de variância (ANOVA), seguida do teste de comparação múltipla de TUKEY-KRAMER. Todos os valores obtidos das diferentes linhagens celulares foram expressos em média \pm desvio médio, considerando como nível crítico para significância valores de $\mathrm{p}<0.05$. 


\section{RESULTADOS}

\subsection{Modelo experimental ortotópico de carcinoma hepatocelular}

Semanalmente, contabilizando a partir do dia zero de inoculação, dois camundongos foram submetidos à eutanásia através do deslocamento cervical, para avaliação do tempo de aparição do tumor e crescimento pela mensuração do comprimento e largura, assim como, foram coletados a massa tumoral e órgãos internos, para análise histológica, avaliação do ciclo celular e expressão de marcadores. Observando-se o estabelecimento do tumor em 21 dias após a inoculação das células tumorais. Notandose a presença de pleomorfismo celular, hepatócitos neoplásicos com citoplasma vacuolizado, áreas de necrose, infiltrado inflamatório mononuclear, dilatação sinusoidal, núcleos hipercromáticos com nucléolos proeminentes e perda da relação no núcleo citoplasma. Além da possível presença de metástases em pulmão e linfonodos inguinais (Figura 1 e 2). 

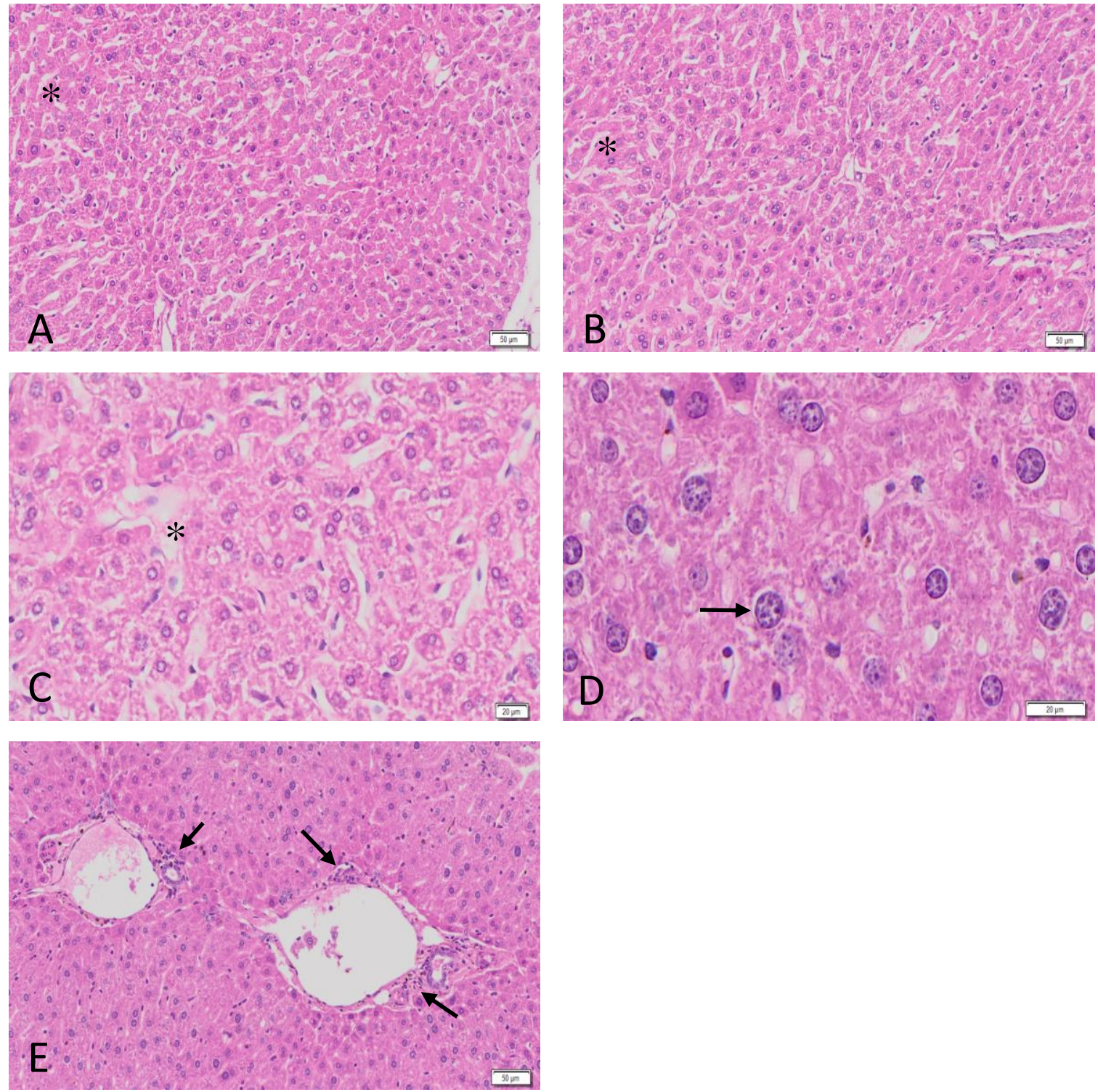

Figura 1 - Carcinoma hepatocelular em camundongos C57BL/6J. A e B: Presença de áreas de dilatação sinusoidal (*). C: Área de necrose (*). D: Hepatócitos neoplásicos com citoplasma vacuolizado com núcleos hipercromáticos com nucléolos proeminentes (seta). E: Infiltrado inflamatório mononuclear na área periportal. 

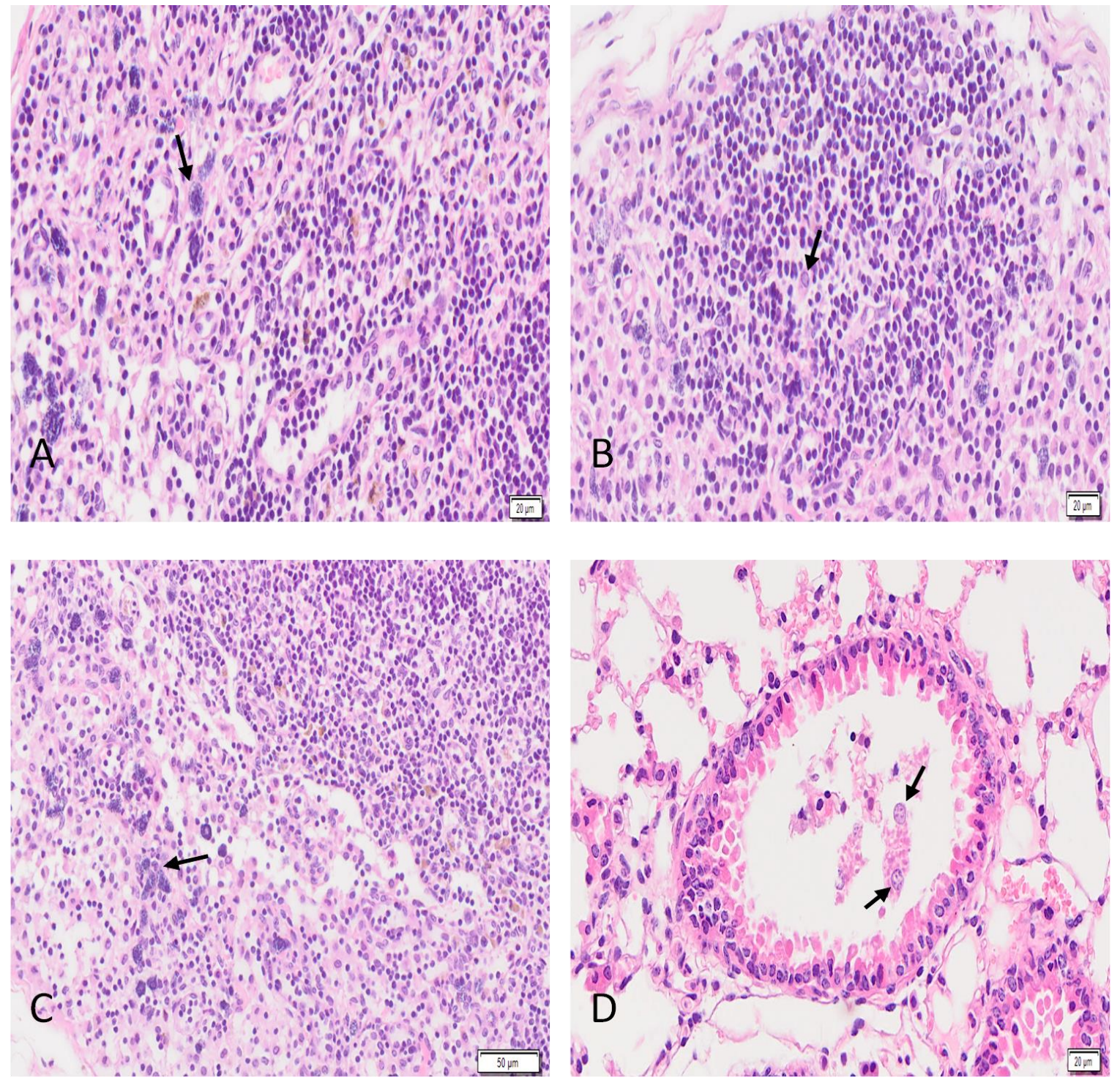

Figura 2 - Infiltrado extra-hepática de carcinoma hepatocelular murino. A, B e C: Linfonodo inguinal com a presença de hepatócitos neoplásicos nas regiões de cortical e centro germinativos (setas). D: Fotomicrografia do parênquima pulmonar com presença de células atípicas. Coloração hematoxilina-eosina. 


\subsection{Análise do perfil hematológico e peso dos animais}

Semanalmente, realizou-se a mensuração do peso e análise hematológica dos animais portadores de carcinoma hepatocelular dos diferentes grupos de estudo. Em relação ao peso dos grupos experimentais 01 (CTMO), 02 (QT1) e 04 (QT1 + CTMO), todos os grupos experimentais apresentaram pesos similares em comparação ao grupo controle (animal saudável) e valores inferiores em relação ao grupo controle tumoral. Os grupos experimentais 01 (CTMO) e 04 (QT1 + CTMO) apresentaram valores médios elevados de eritrócitos, em comparação com o grupo tratado apenas com a doxorrubicina como protocolo quimioterápico (QT1), que apresentaram níveis abaixo do grupo controle tumoral. No que se diz respeito aos níveis de plaquetas, o grupo experimental 04 (QT1 + CTMO) apresentou valores semelhantes aos do grupo controle. Já os outros grupos experimentais 01 e 02 (CTMO e QT1) obtiveram valores próximo ao grupo controle tumoral e inferiores ao grupo controle. O número de leucócitos totais foi maior no grupo controle tumoral. O grupo experimental 04 (QT1 + CTMO) apresentou melhor resposta ao tratamento em comparação com os outros grupos experimentais 01 e 02 (CTMO e QT1) que apresentaram leucopenia acentuada em comparação ao grupo controle (Figura 3). 


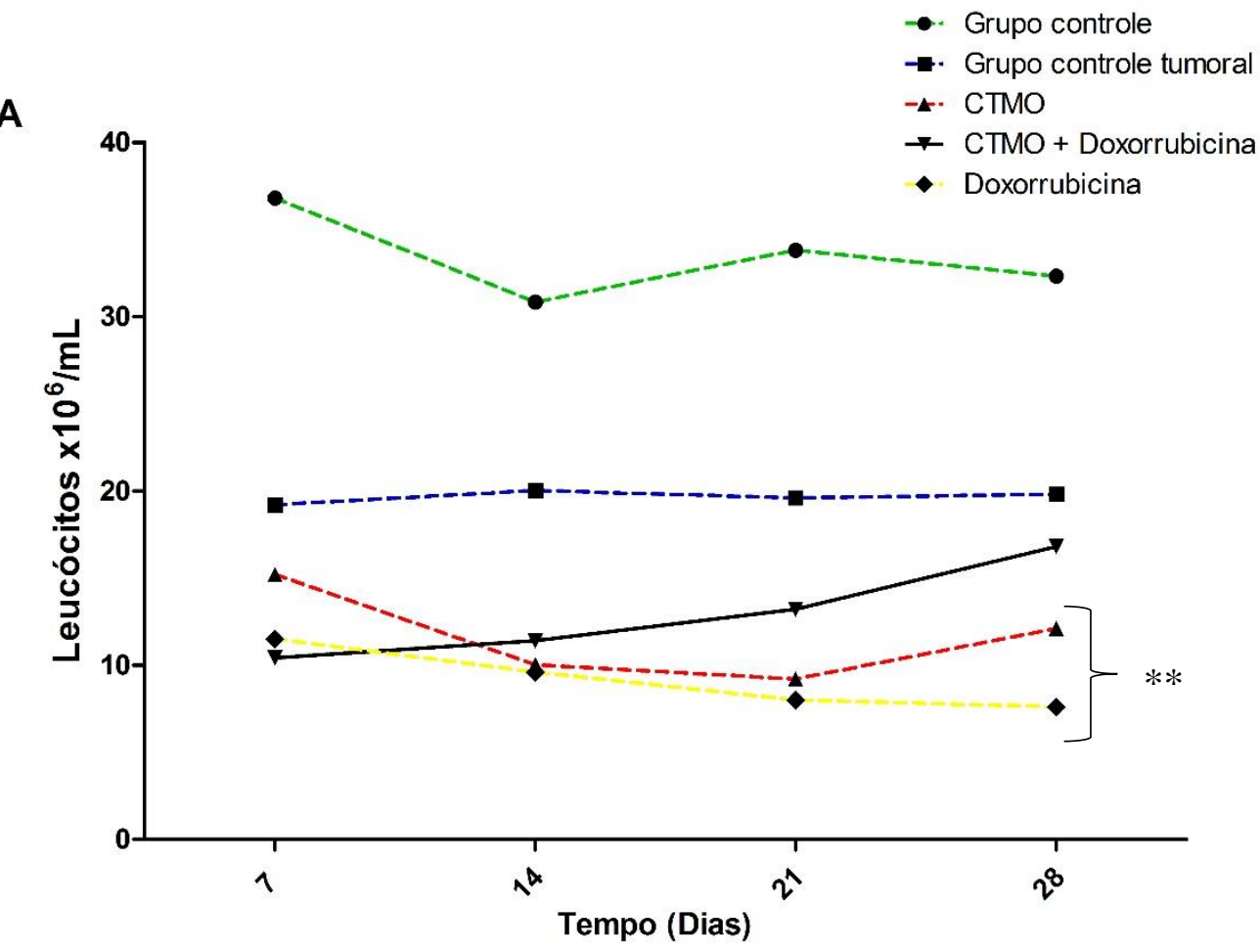

B

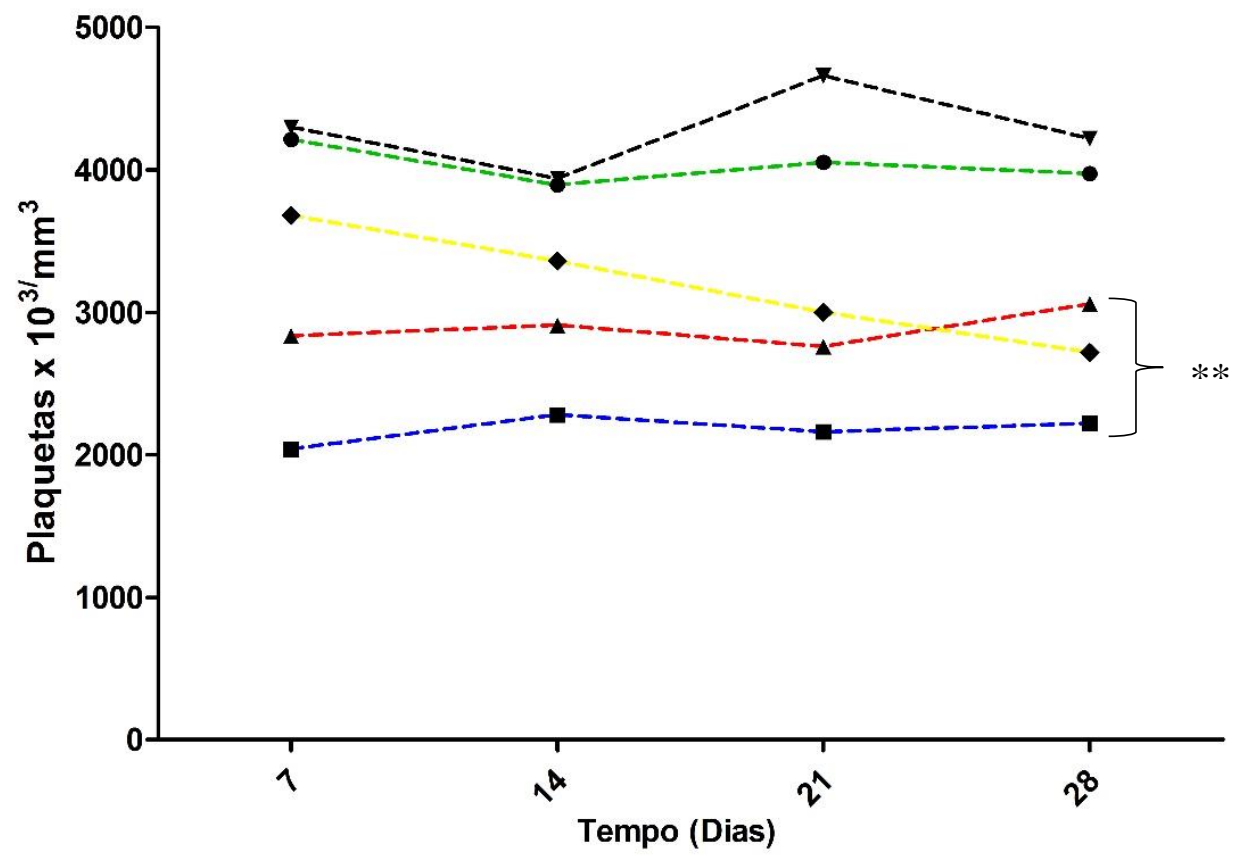




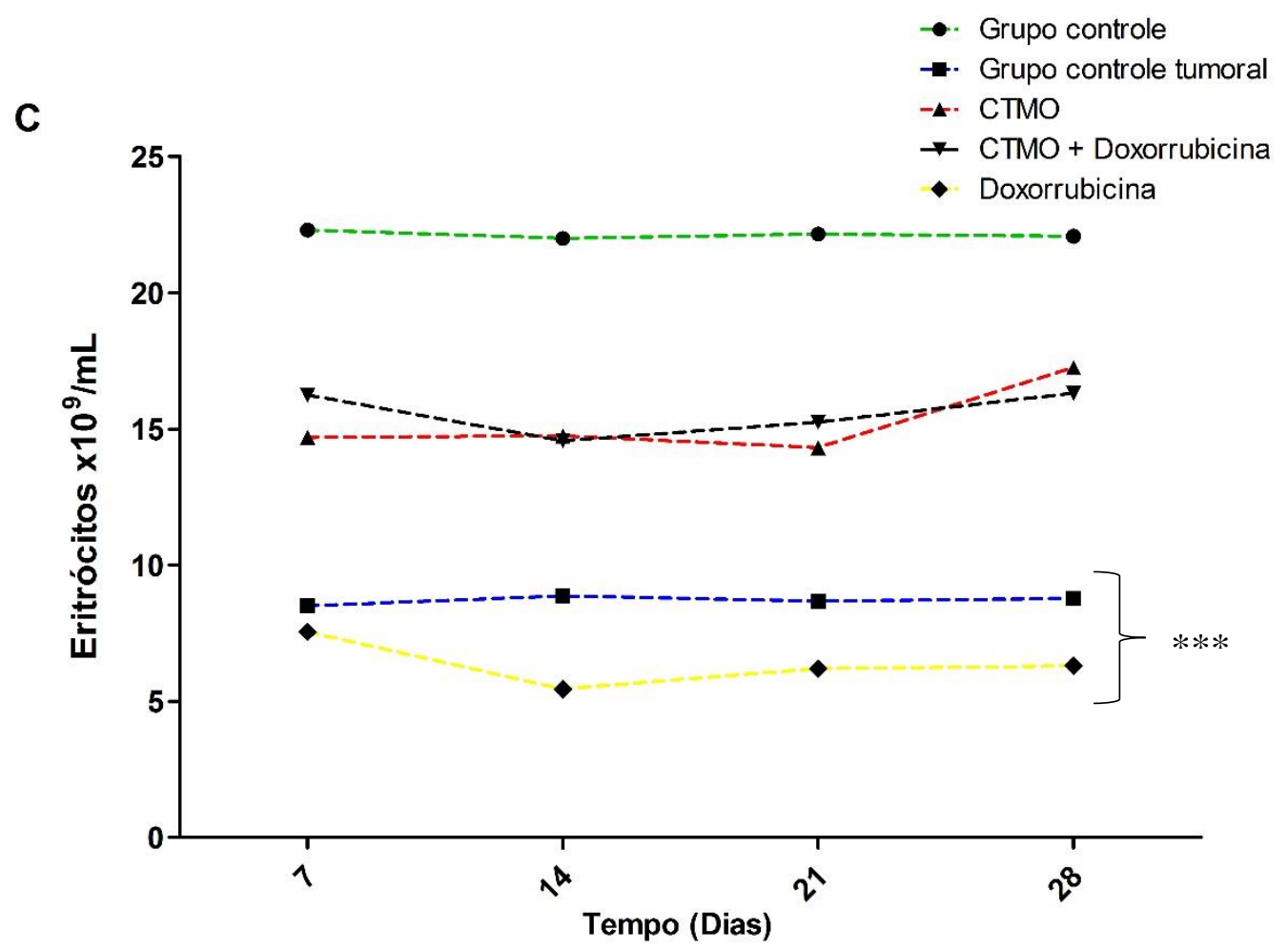

D

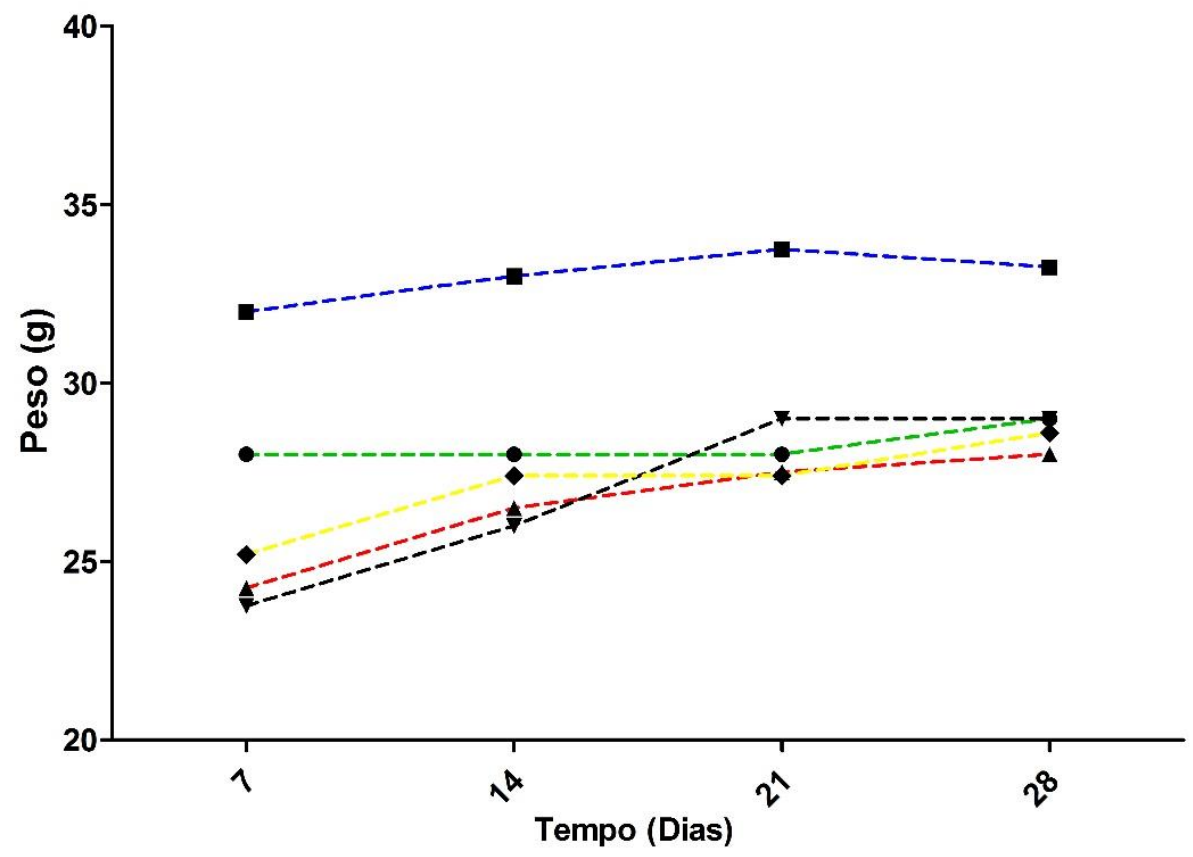

Figura 3 - Número de leucócitos totais (A), plaquetas (B), eritrócitos (C) e peso corpóreo (D) de camundongos C57BL/6J, grupo experimental doxorrubicina. Resultados expressos em média $\pm \mathrm{dp}$. Análise estatística de variância ANOVA seguida pelo teste múltiplo de TUKEY-KRAMER. $* * * p<0,001 \mathrm{e}^{* *} \mathrm{p}<0,01$. Diferenças estatísticas entre os grupos tratados CTM ou quimioterápico e controle tumoral. 
As diferenças encontradas entre os pesos médios dos animais tratados com células-tronco mesenquimais (CTMO), gencitabina combinada com células-tronco mesenquimais (QT2 + CTMO) e gencitabina (QT2), foram semelhantes aos grupos experimentais anteriores. As médias de peso foram similares ao grupo controle (animal saudável) e inferiores em comparação ao grupo controle tumoral, embora a diferença estatística não seja significativa. Além dos grupos experimentais 01 (CTMO) e 05 (QT2 + CTMO) apresentarem melhores níveis médios de eritrócitos ao contrário do grupo experimental tratado somente com gencitabina (QT2) que obteve níveis similares aos do grupo controle tumoral. Entre os grupos experimentais, o grupo 05 (QT2 + CTMO) apresentou os melhores níveis de plaquetas quando comparado ao grupo controle.

O grupo controle tumoral obteve os mais baixos níveis de plaquetas entre os outros grupos estudados. Os números de leucócitos totais foram maiores no grupo controle tumoral. Já o grupo experimental 05 (QT2 + CTMO) apresentou melhor resposta ao tratamento em comparação com os outros grupos experimentais 01 e 03 (CTMO e QT2) que apresentaram leucopenia acentuada em comparação ao grupo controle, animal saudável (Figura 4). 


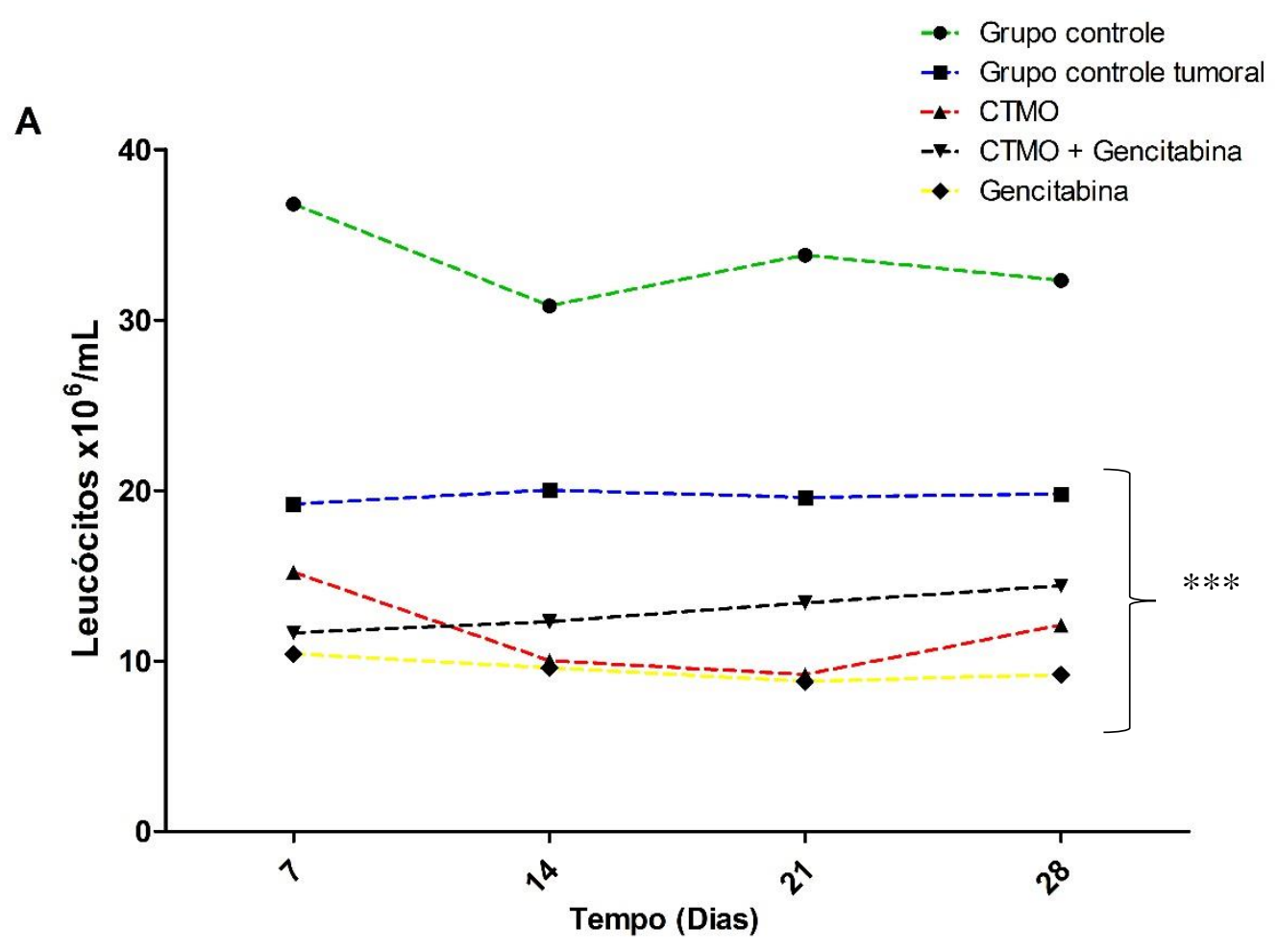

B

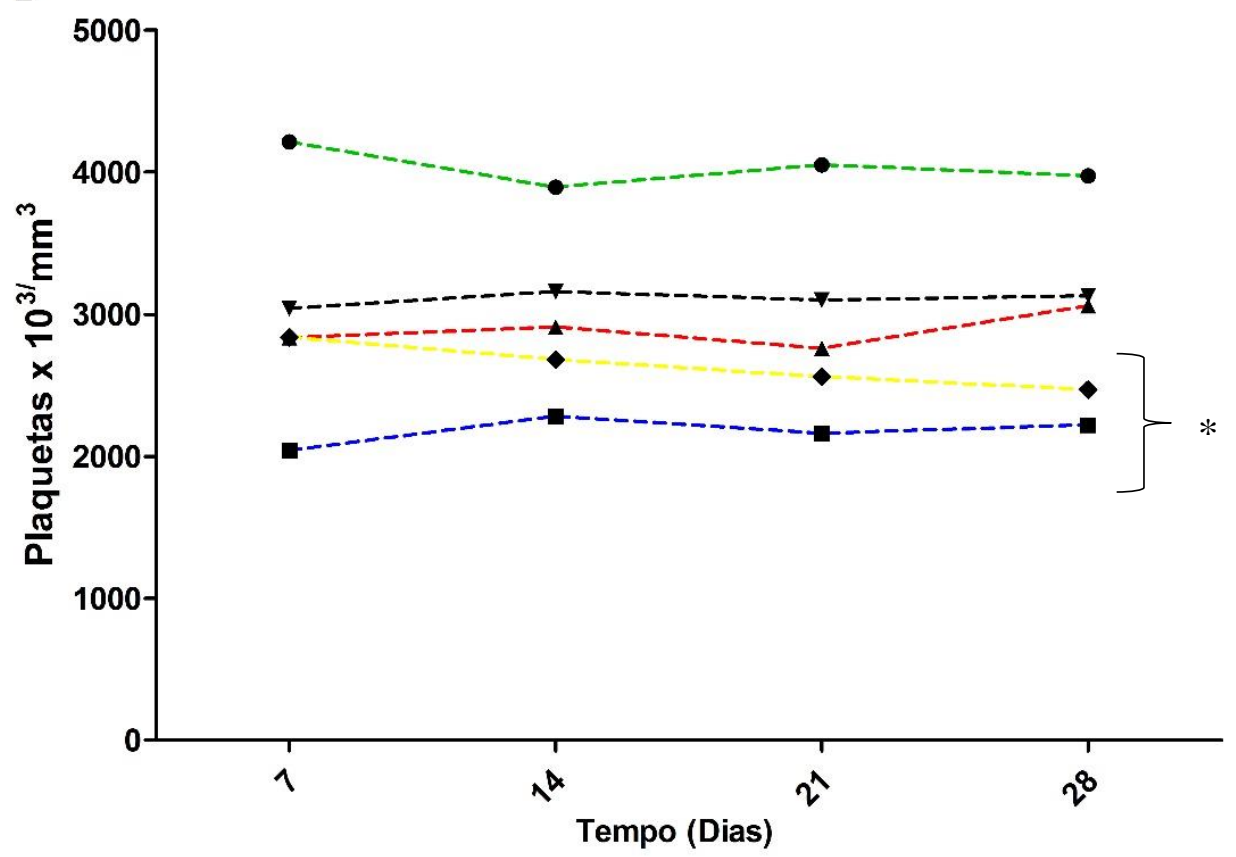



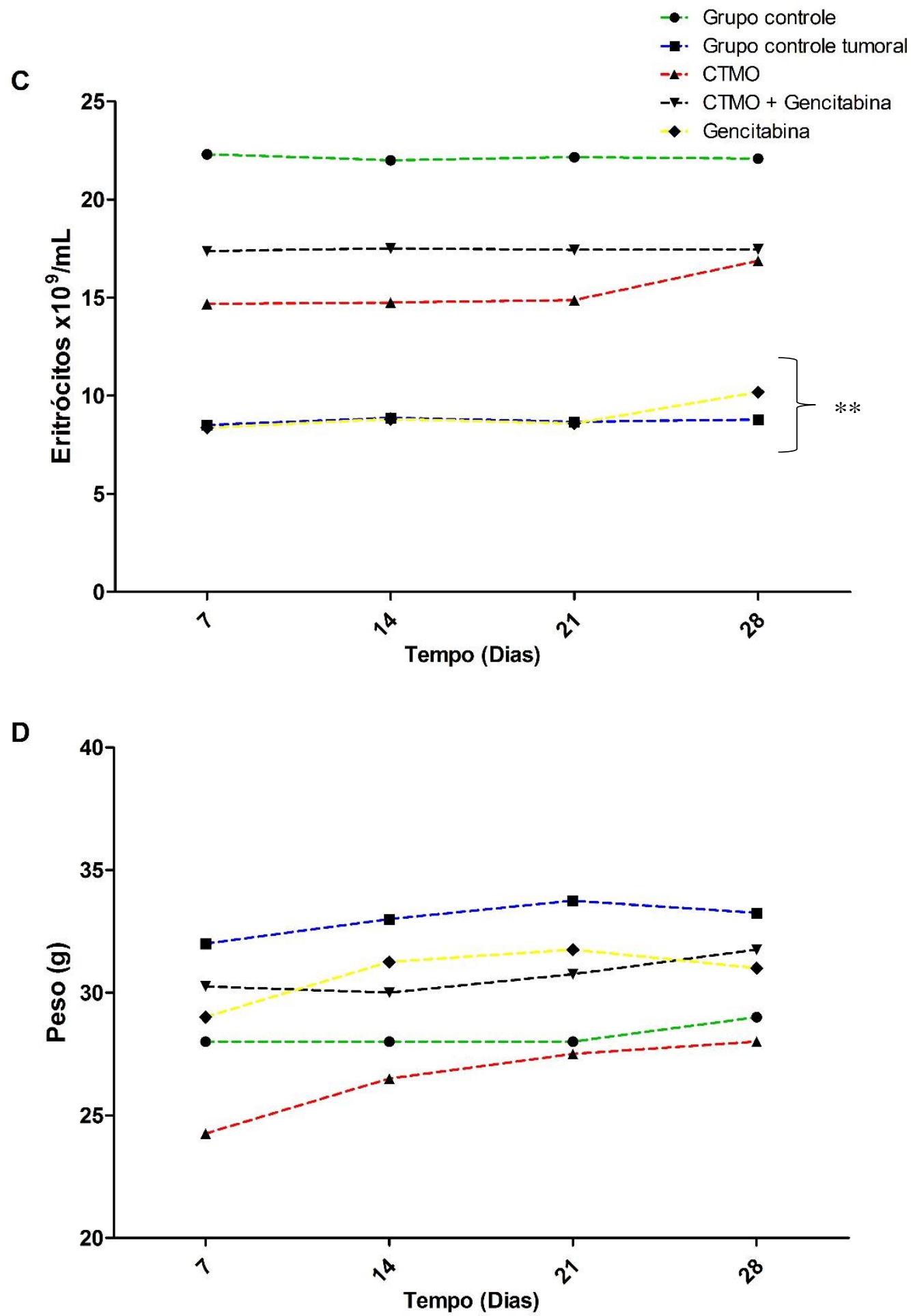

Figura 4 - Número de leucócitos totais (A), plaquetas (B), eritrócitos (C) e peso corpóreo (D) de camundongos C57BL/6J, grupo experimental gencitabina. Resultados expressos em média $\pm \mathrm{dp}$. Análise estatística de variância ANOVA seguida pelo teste múltiplo de TUKEY-KRAMER. $* * * p<0,001 ; * * p<0,01 \mathrm{e} * \mathrm{p}<0,05$. Diferenças estatísticas entre os grupos tratados CTM ou quimioterápico e controle tumoral. 
Em relação ao número de reticulócitos ambos os grupos tratados somente com os quimioterápicos (doxorrubicina e gencitabina) apresentaram os menores valores em comparação as demais modalidades terapêuticas estudadas. Já os grupos tratados somente com células-tronco mesenquimais apresentaram os maiores valores dos demais grupos estudados. Além de se obter resultados superiores dos grupos tratados com células-tronco mesenquimais em associação aos quimioterápicos (doxorrubicina e gencitabina) em relação ao grupo controle (Figura 5). 
A

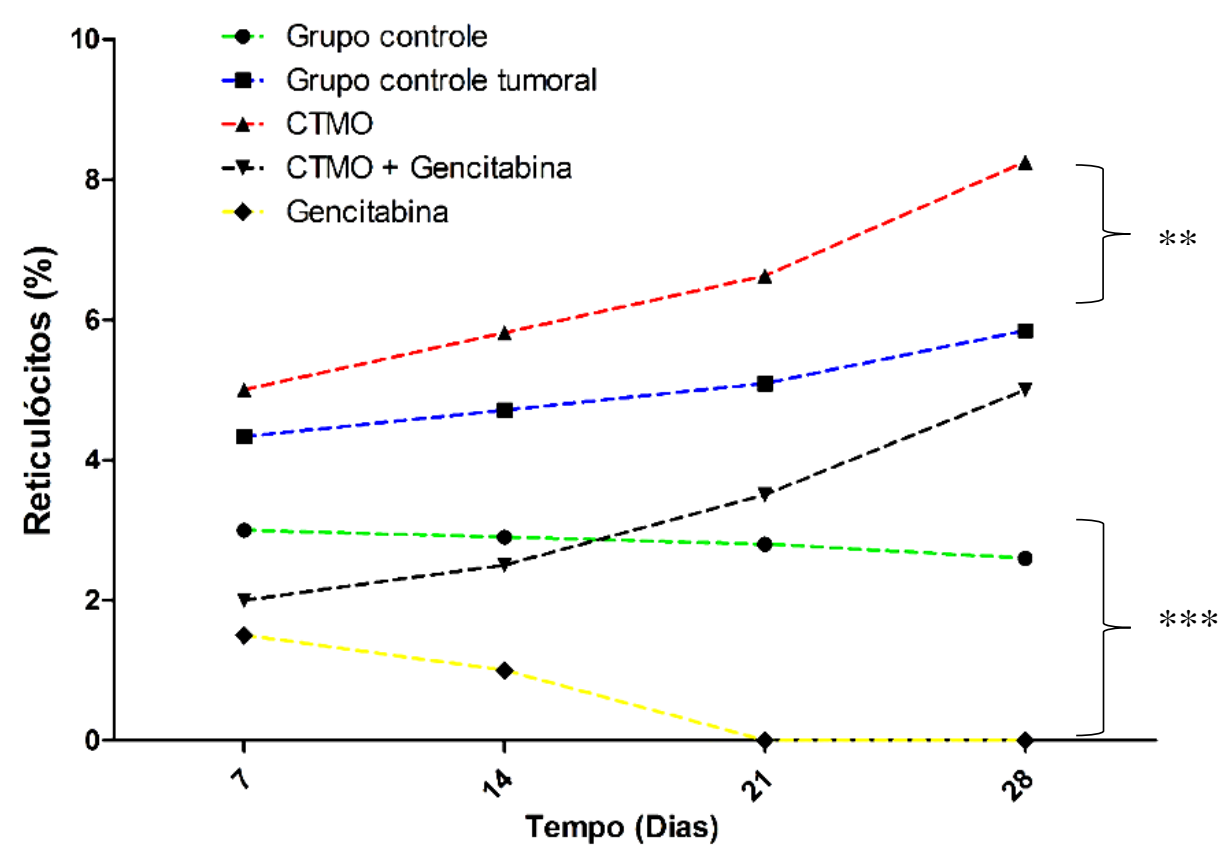

B

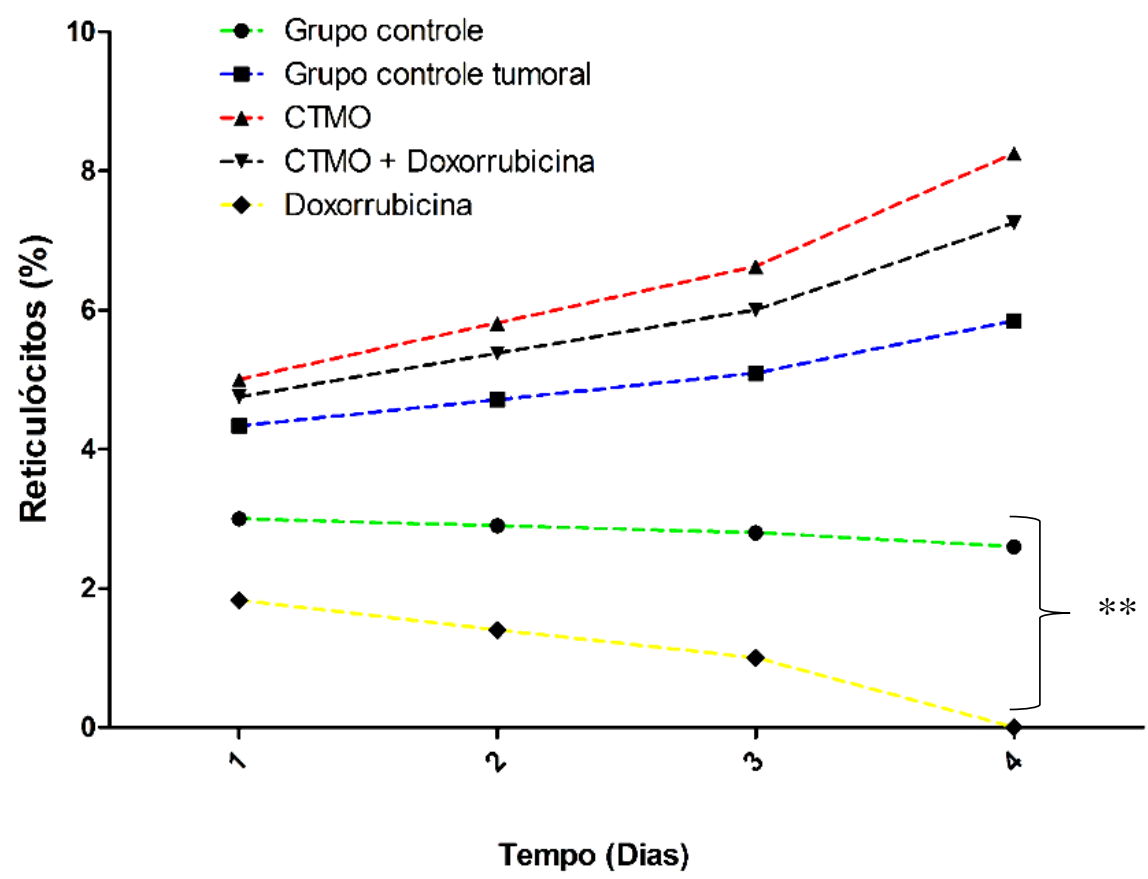

Figura 5 - Contagem de retículócitos de camundongos C57BL/6J. Resultados expressos em média \pm dp. Análise estatística de variância ANOVA seguida pelo teste múltiplo de TUKEY-KRAMER. ${ }^{* * *} p<0,001 ;{ }^{* *} p<0,01$ e ${ }^{*} p<0,05$. Diferenças estatísticas entre os grupos tratados CTM ou quimioterápico e controle tumoral. 


\subsection{Avaliação da redução do volume do tumor hepático}

Em relação as diferenças obtidas subtraindo-se o volume do tumor, expressos em porcentagem, do grupo controle tumoral em comparação com os diferentes grupos de estudo (CTMO, QT1, QT2, QT1 + CTMO e QT2 + CTMO). O grupo experimental tratado apenas com células-tronco mesenquimais apresentou a maior redução do volume $(30,5 \%)$, quando comparado aos demais grupos de tratamento, embora a diferença estatística não seja significativa (Figura 6).

2,5

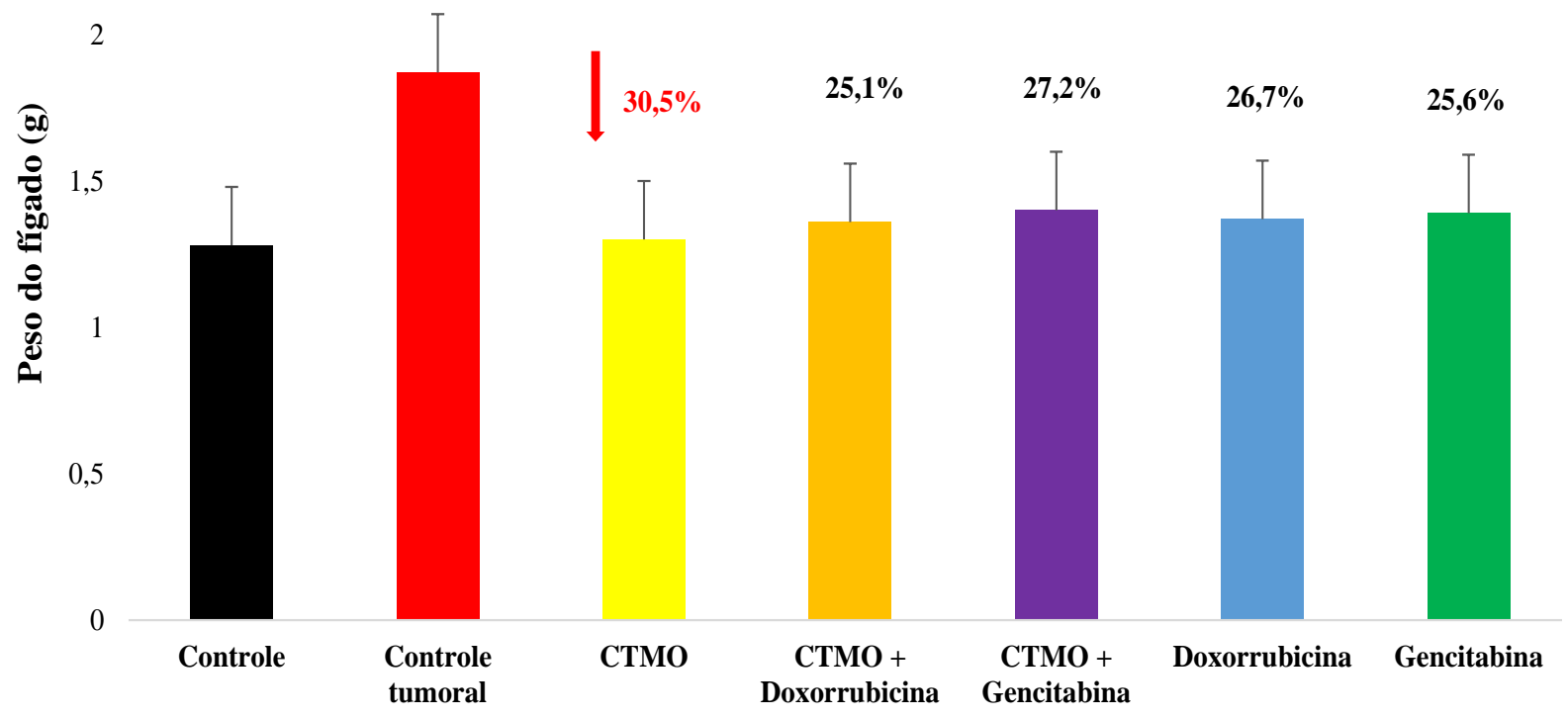

Figura 6 - Avaliação da redução do volume tumoral em camundongos C57BL/6J portadores de carcinoma hepatocelular em comparação com os diferentes grupos de estudo. Resultados expressos em porcentagem média \pm dp. Análise estatística de variância ANOVA seguida pelo teste múltiplo de TUKEY-KRAMER.

ns - não significativo

$* * * \mathrm{p}<0,001 ; * * \mathrm{p}<0,01$ e $* \mathrm{p}<0,05$. 


\subsection{Determinação da atividade citotóxica dos quimioterápicos doxorrubicina e gencitabina em células de carcinoma hepatocelular murino (Hepa1c1c7) pelo método colorimétrico MTT.}

Após a cultura da linha celular de carcinoma hepatocelular murino, as células foram incubadas com o reagente MTT para determinar a viabilidade celular. $\mathrm{O}$ intervalo usado para determinação matemática da equação da reta, a concentração inibidora de $50 \%$ (IC50) e o coeficiente de correlação $\left(\mathrm{r}^{2}\right)$ foi de $(0,05 \mu \mathrm{M}$ a $3,4 \mu \mathrm{M})$ para doxorrubicina e $(1,46 \mu \mathrm{M}$ a 93,7 $\mu \mathrm{M})$ de gencitabina. A concentração inibidora $\left(\mathrm{IC}_{50}\right)$ foi calculada a partir da equação da reta e ambos os valores do coeficiente de correlação foram maiores do que 0,95, o qual demonstra uma correlação altamente positiva e significativa. Após o tratamento da linhagem celular de carcinoma (Hepa1c1c7) com os quimioterápicos doxorubicina e gencitabina obteve-se $\left(\mathrm{IC}_{50}\right)$ nas concentrações de $1,85 \mu \mathrm{M}$ para doxorrubicina e 20,8 $\mu \mathrm{M}$ para gencitabina. Demonstrando que é necessária uma concentração mais baixa de doxorrubicina para induzir citotoxicidade nesta linhagem tumoral, em comparação com a concentração inibitória de gencitabina (Figura 7). 

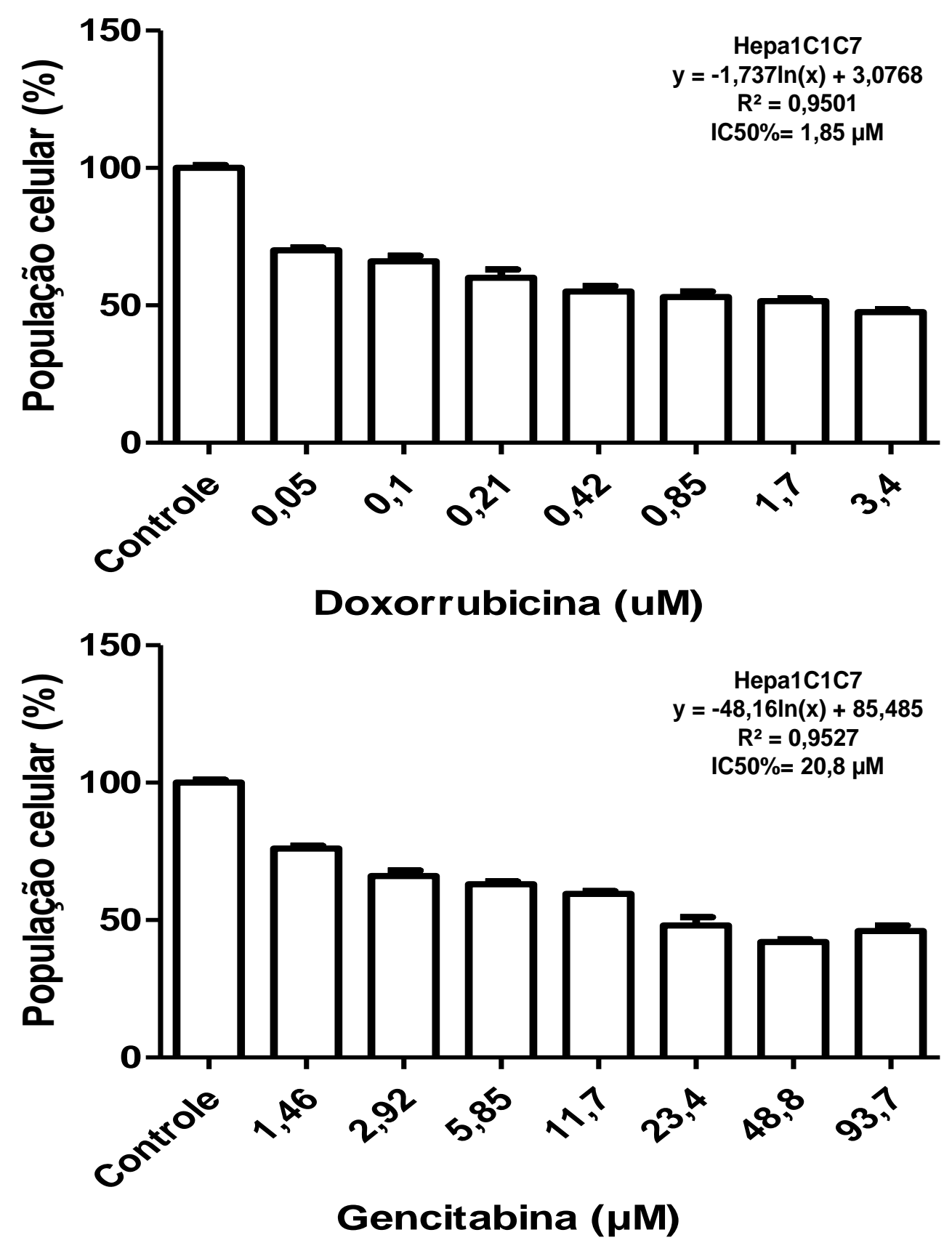

Figura 7 - Gráfico de viabilidade celular obtida pelo teste de MTT para determinação da $\mathrm{IC}_{50} \mathrm{em}$ linhagem de hepatocarcinoma murino (Hepa1c1c7) após 24 horas de tratamento com os quimioterápicos doxorrubicina e gencitabina. Os valores da densidade óptica nas diferentes concentrações foram plotados e foram calculadas a equação da reta e a curva de regressão linear no programa Graph Pad Prism Instat 5. 


\subsection{Determinação da peroxidação de lipídeos da membrana celular}

A formação de substâncias reativas ao ácido tiobarbitúrico (TBARS) nas diferentes modalidades de tratamento foi avaliada por radicais livres formados a partir da peroxidação das membranas celulares, principalmente o malondialdeído. A quantificação de TBARS na linhagem celular de carcinoma hepatocelular murino (Hepa1c1c7) tratados com os quimioterápicos doxorrubicina e gencitabina demonstrou efeito deletério apenas quando tratados nas concentrações $(55 \mu \mathrm{M}$ a $250 \mu \mathrm{M})$ com a doxorrubicina e $(218,75 \mu \mathrm{M}$ a 7,000 $\mu \mathrm{M}$ ) com gencitabina (Figura 8). 


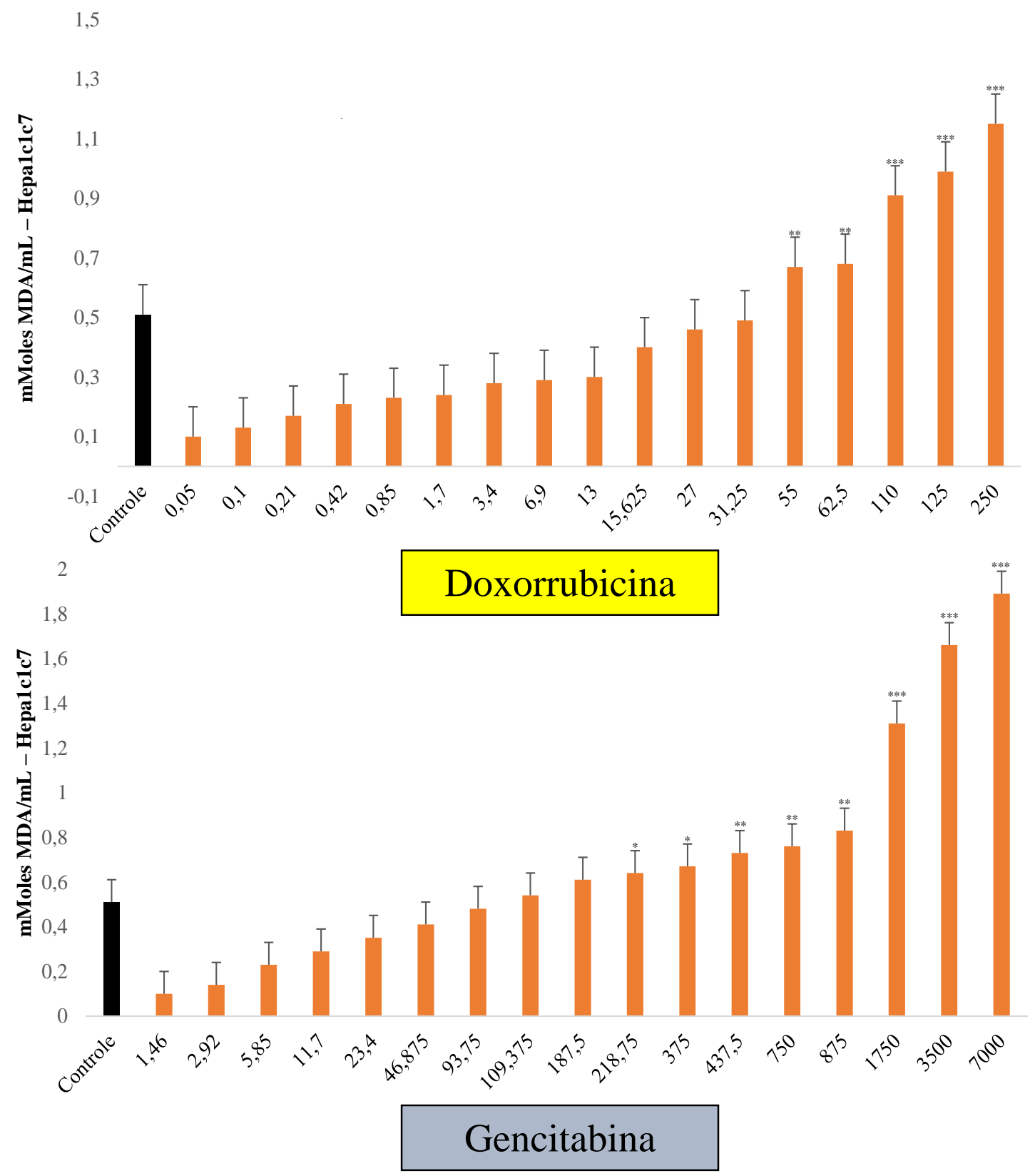

Figura 8 - Valores das médias \pm dp dos radicais livres poli-insaturados peroxidados formados no sobrenadante da linhagem de hepatocarcinoma murino (Hepa1c1c7) tratada com os quimioterápicos doxorrubicina e gencitabina.

Análise estatística de variância ANOVA seguida pelo teste múltiplo de TUKEYKRAMER. $\quad * * * p<0,001 ; * * p<0,01$ e $* \mathrm{p}<0,05$. 


\subsection{Aspectos citológicos da linhagem de carcinoma hepatocelular murino (Hepac1c1c7)}

As células de carcinoma hepatocelular murino (Hepa1c1c7) foram tratadas nas diferentes concentrações dos quimioterápicos doxorrubicina $(0,05 \mu \mathrm{M}$ a $3,4 \mu \mathrm{M})$ e gencitabina $(1,46 \mu \mathrm{M}$ a 93,7 $\mu \mathrm{M})$. Após 24 horas de tratamento, as células foram foto documentadas em aumento de 40 vezes no microscópio óptico de inversão mais o aumento de três vezes da aquisição digitalizada em pixels em câmera digital (CCD Sony®). As células tumorais apresentaram perda significativa da densidade celular em todas as concentrações analisadas, com presença de corpos apoptóticos, além de apresentarem perda dos contornos celulares e formação de debris celulares (Figuras 9 e $10)$. 

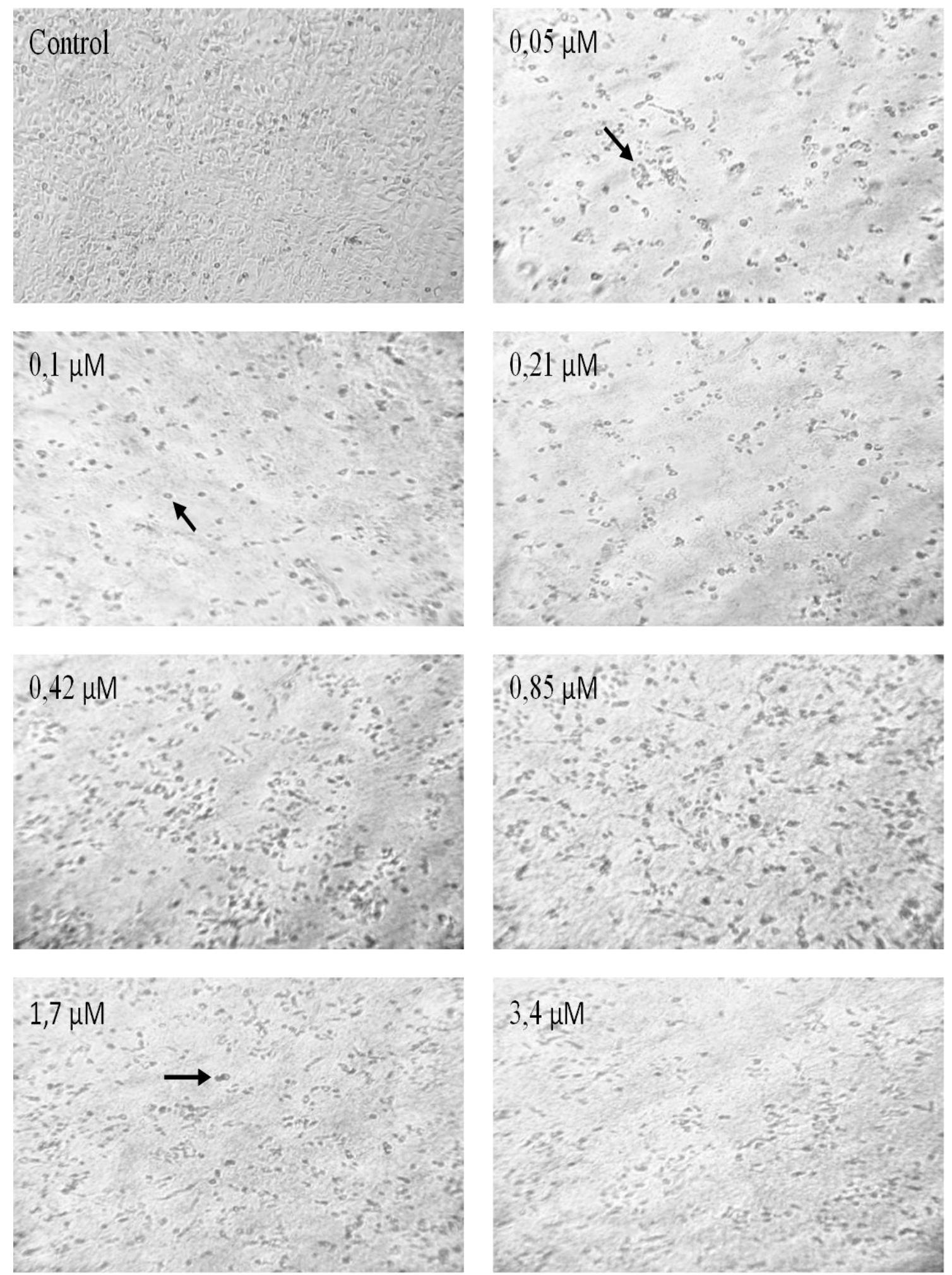

Figura 9 - Aspecto morfológica da linhagem celular de carcinoma hepatocelular (Hepa1c1c7) tratadas com diferentes concentrações de doxorrubicina. Nota-se perda significativa da densidade celular em todas as concentrações analisadas, com presença de corpos apoptóticos, além de apresentarem perda dos contornos celulares e formação de debris celulares, como indicado nas setas. 

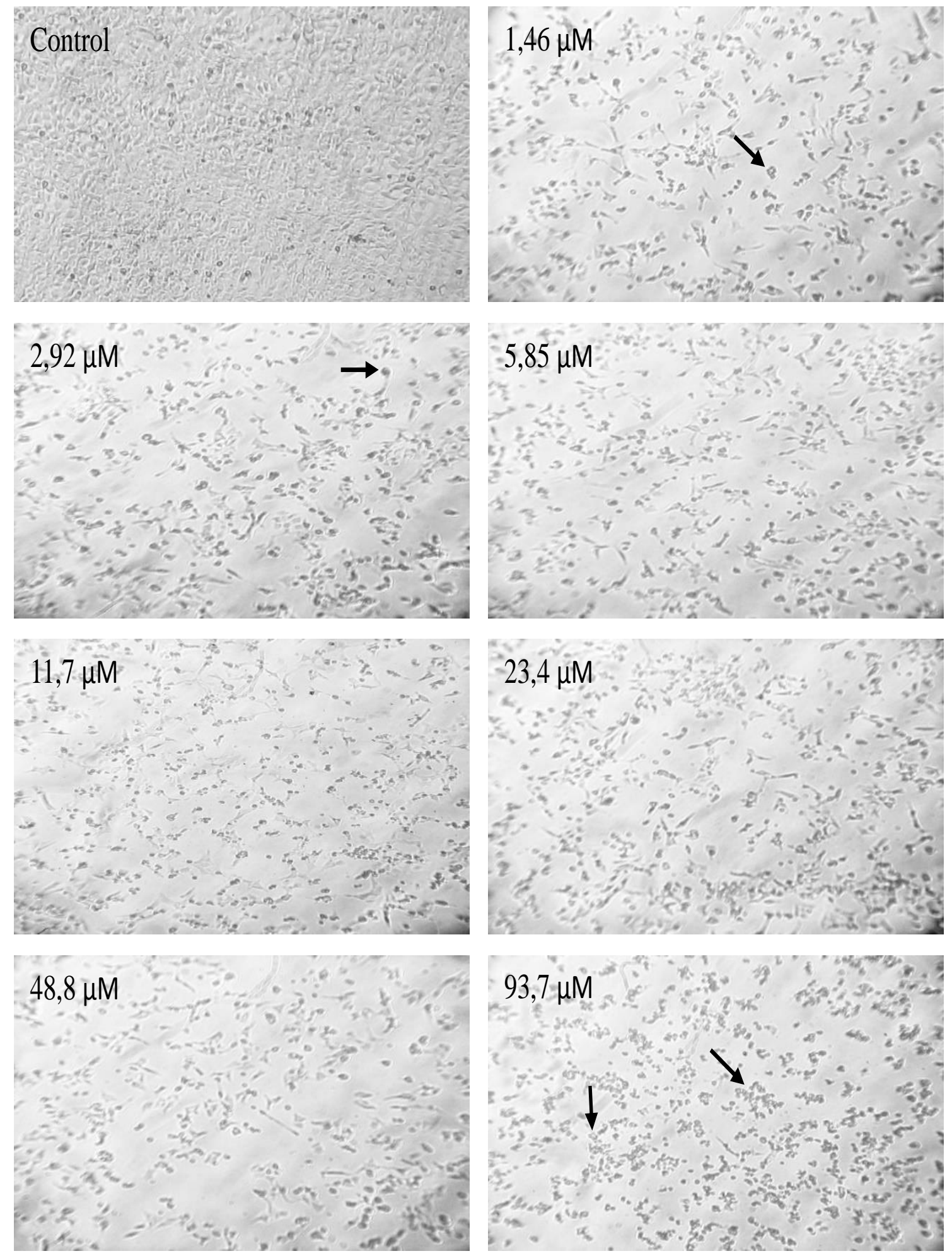

Figura 10 - Aspectos morfológicos da linhagem celular de carcinoma hepatocelular (Hepa1c1c7) tratadas com diferentes concentrações de gencitabina. Nota-se perda significativa da densidade celular em todas as concentrações analisadas, com presença de corpos apoptóticos, além de apresentarem perda dos contornos celulares e formação de debris celulares, como indicado nas setas. 


\subsection{Análises das fases do ciclo celular "in vitro" por citometria de fluxo}

As células de carcinoma hepatocelular murino foram tratadas por 24 horas com as concentrações inibitórias de $\mathrm{IC}_{50}$ dos quimioterápicos doxorrubicina $(1,85 \mu \mathrm{M})$ e gencitabina $(20,8 \mu \mathrm{M})$, ambos diluídos em solução salina. Os resultados foram expressos em gráfico de tipo barras com porcentagem média de células em diferentes fases do ciclo celular: sub-G1 (DNA fragmentado), G0/G1, fase S e G2/M. Ambas as modalidades terapêuticas apresentaram resultados semelhantes, tais como o aumento da população de células em fase sub-G1 e G0/G1. Além de induzir significativamente diminuição da população celular nas fases S e G2/M (Figura 11). 


\section{Grupo controle (Hepa1c1c7)}

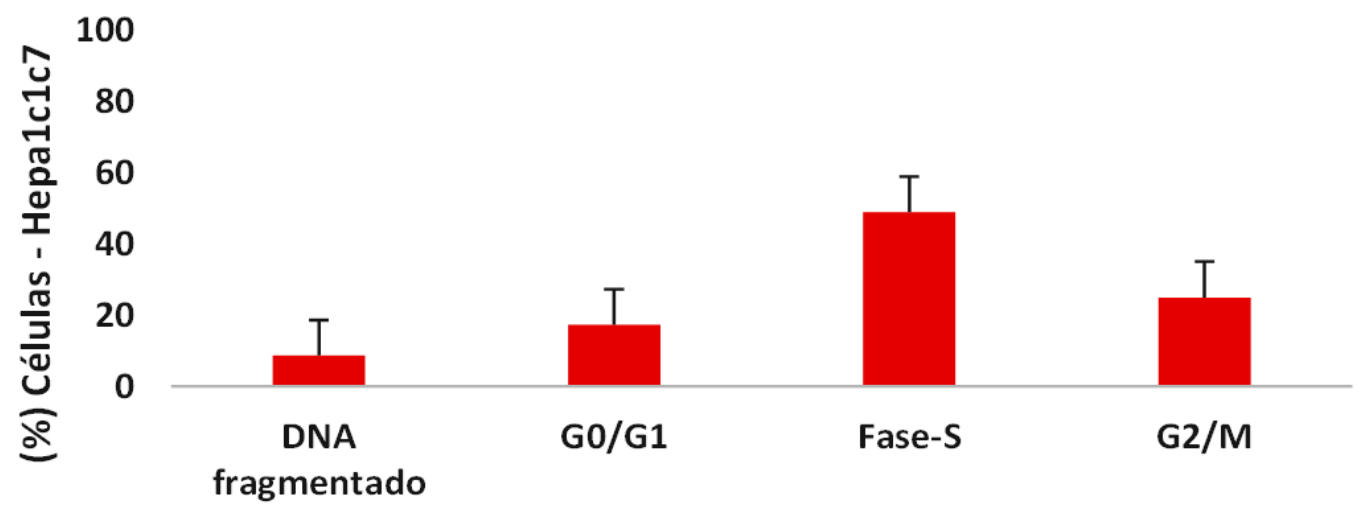

\section{Doxorrubicina}

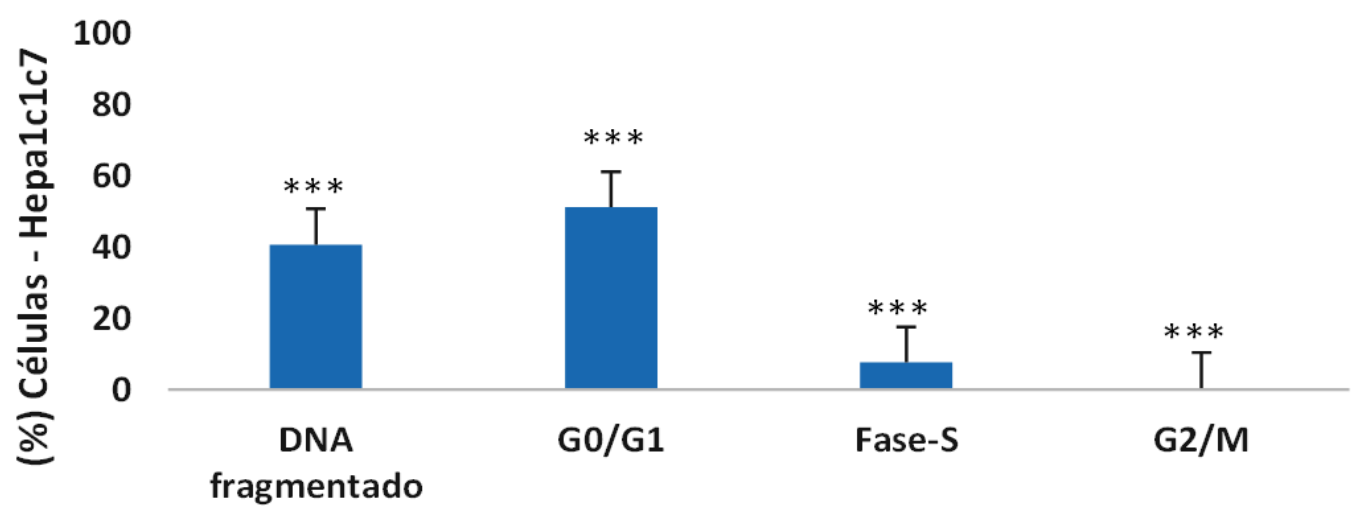

\section{Gencitabina}

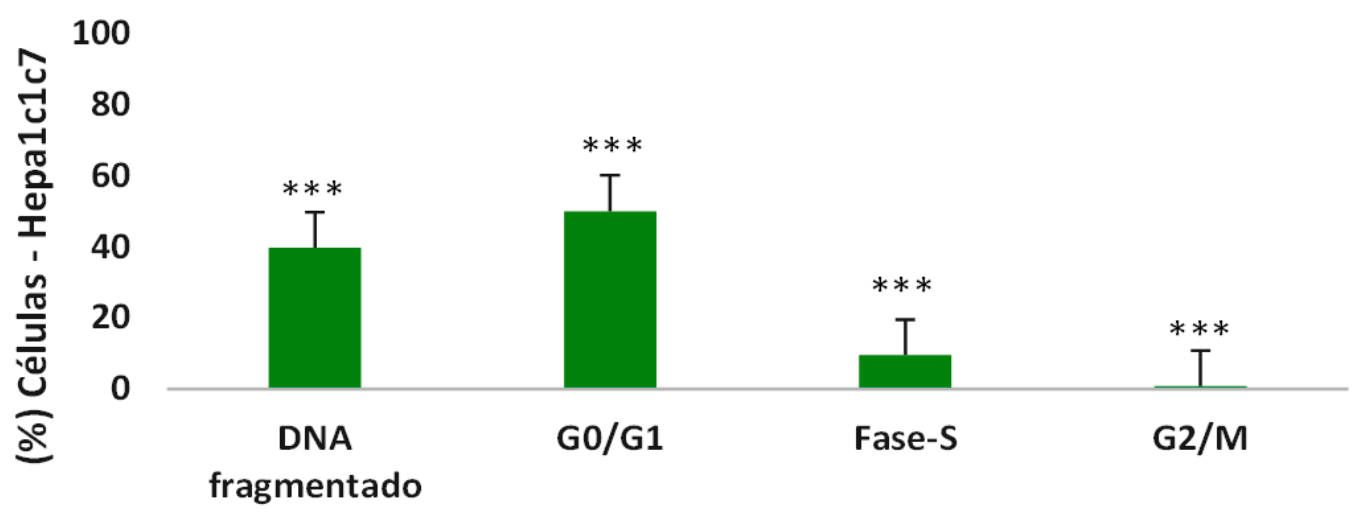

Figura 11 - Gráfico de barras das médias \pm dp das células de hepatocarcinoma murino (Hepa1c1c7) tratadas com as concentrações inibitórias de $\mathrm{IC}_{50}$ dos quimioterápicos doxorrubicina e gencitabina distribuídas nas diferentes fases do ciclo celular. Adquiridos em citometria de fluxo e analisados no programa WinMDI 2.8. Análise estatística de variância ANOVA seguida pelo teste múltiplo de TUKEY-KRAMER.

$* * * p<0,001 ; * * p<0,01$ e $* \mathrm{p}<0,05$. 


\subsection{Análises das fases do ciclo celular "in vivo" por citometria de fluxo}

As células tumorais dos nódulos do carcinoma hepatocelular presentes no parênquima hepático dos diferentes grupos de tratamento foram isoladas a partir do homogenato da massa tumoral por meio da filtração celular por membranas com poros de $70 \mu \mathrm{M}$ (Falcon, USA). Os resultados foram expressos em gráficos do tipo barras com porcentagem média de células nas diferentes fases do ciclo celular: sub-G1 (DNA fragmentado), G0/G1, fase $\mathrm{S}$ de síntese e fase G2/M em divisão.

A população celular encontrada na fase sub-G1 foi significativamente maior nos grupos de animais tratados com células-tronco mesenquimais em associação ao quimioterápico gencitabina $(39,4 \%)$, tratados com células-tronco mesenquimais em associação ao quimioterápico doxorrubicina $(30,14 \%)$, somente com o quimioterápico doxorrubicina $(26,14 \%)$ e o grupo tratado somente com o quimioterápico gencitabina $(19,84 \%)$ além de induzir significativamente diminuição das fases S e G2/M.

Já o grupo tratado somente com células-tronco mesenquimais não apresentou eficácia como as outras modalidades de tratamento em comparação ao grupo controle tumoral não tratado (Figura 12). 
Grupo controle (Carcinoma hepatocelular)

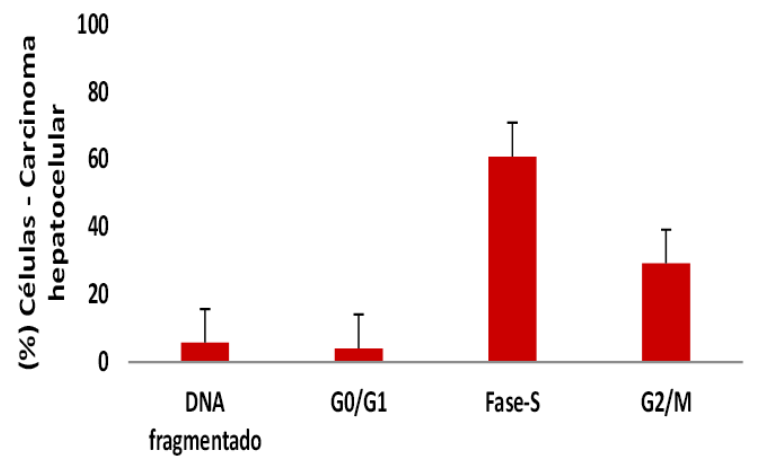

Células-tronco mesenquimais (CTM)

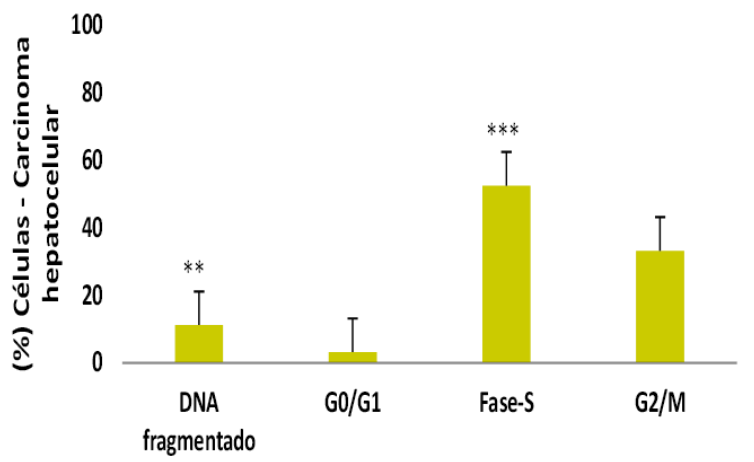

Doxorrubicina

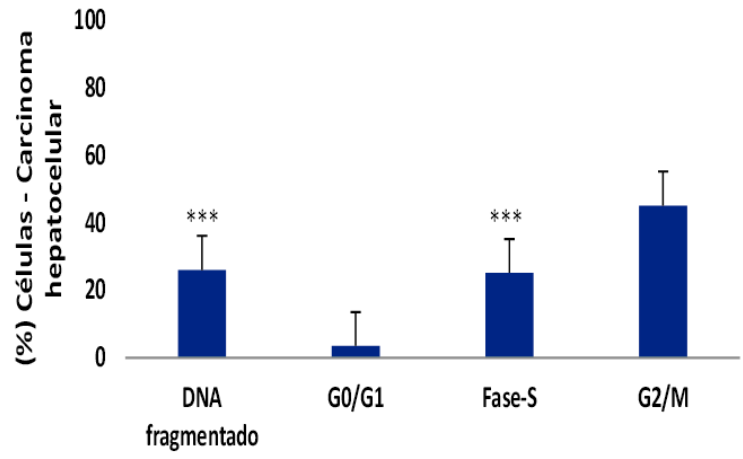

Gencitabina

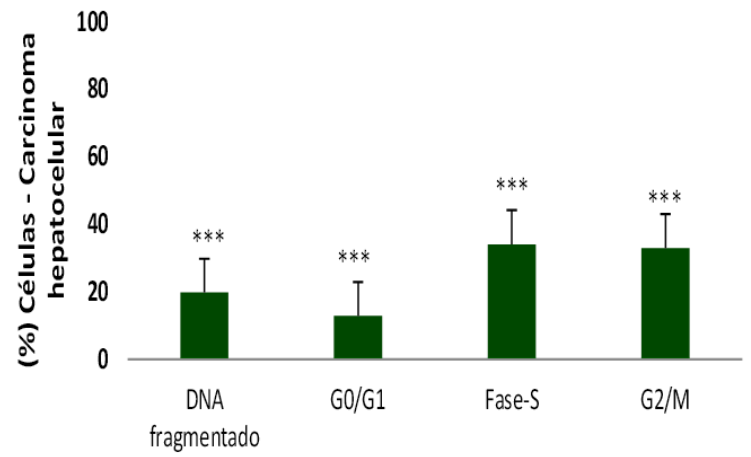

CTM + Doxorrubicina

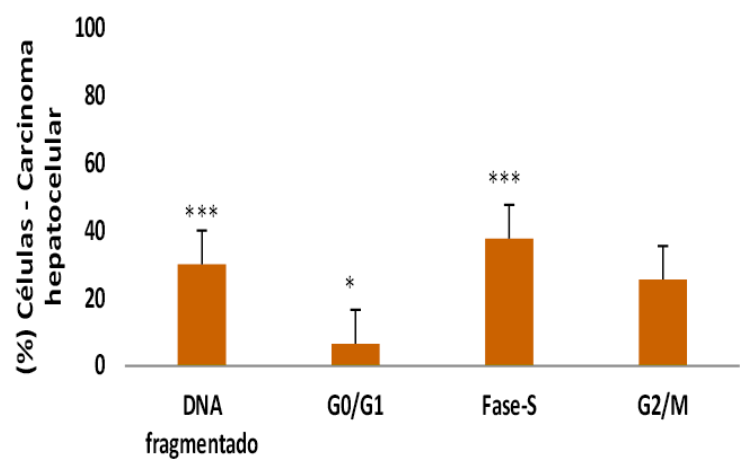

CTM + Gencitabina

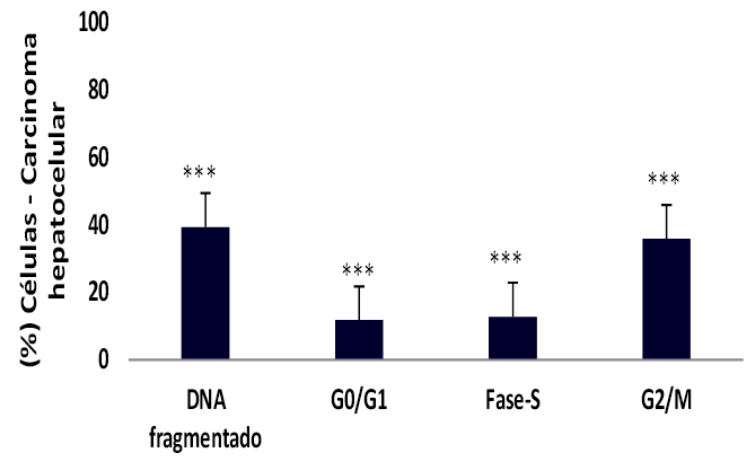

Figura 12 - Gráfico de barras das médias \pm dp das células oriundas do homogenato da massa tumoral hepática tratadas com os quimioterápicos doxorrubicina, gencitabina, células-tronco mesenquimais e em associação a quimioterapia sistêmica, distribuídas nas diferentes fases do ciclo celular. Adquiridos em citometria de fluxo e analisados no programa WinMDI 2.8. Análise estatística de variância ANOVA seguida pelo teste múltiplo de TUKEY-KRAMER. ***p<0,001; **p<0,01 e *p<0,05. 


\subsection{Análise da expressão de marcadores “in vivo” por citometria de fluxo}

Os mecanismos envolvidos nas alterações celulares causadas pelas diversas modalidades de tratamento foram estudados pelas expressões de marcadores que controlam a morte celular (caspase 3 ativada e caspase 8) e na expressão dos marcadores (CD90, CD44, IL1-R, IL2-R e CD14). No grupo de animais tratado com células-tronco mesenquimais em associação ao quimioterápico gencitabina há um aumento da expressão das caspase 3 ativada e caspase 8, CD44 e IL-1R. O grupo de animais tratados com células-tronco mesenquimais apresentou aumento na expressão dos marcadores CD90 e CD14 (Figura 13). 


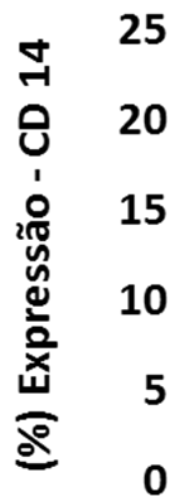<smiles>[CH][Co]</smiles>

$c^{0}$

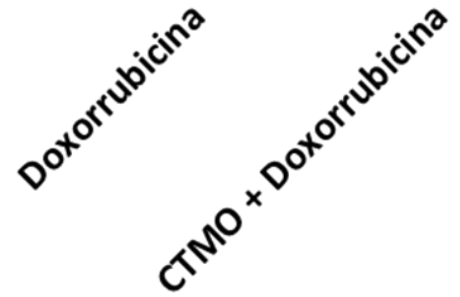

A

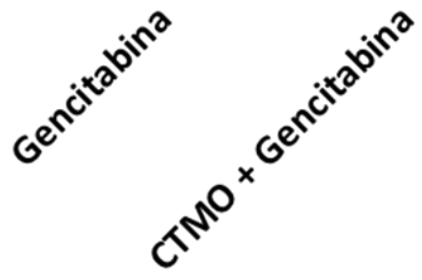

16

B

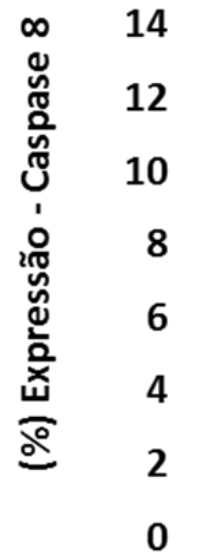<smiles>[CH][Co]</smiles><smiles>[CH-]=O</smiles>
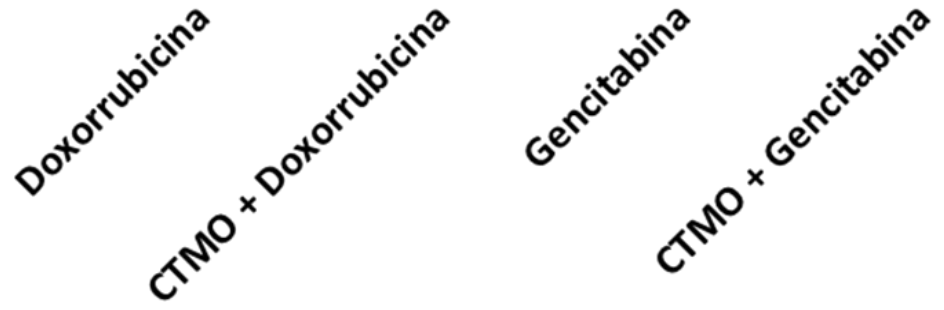

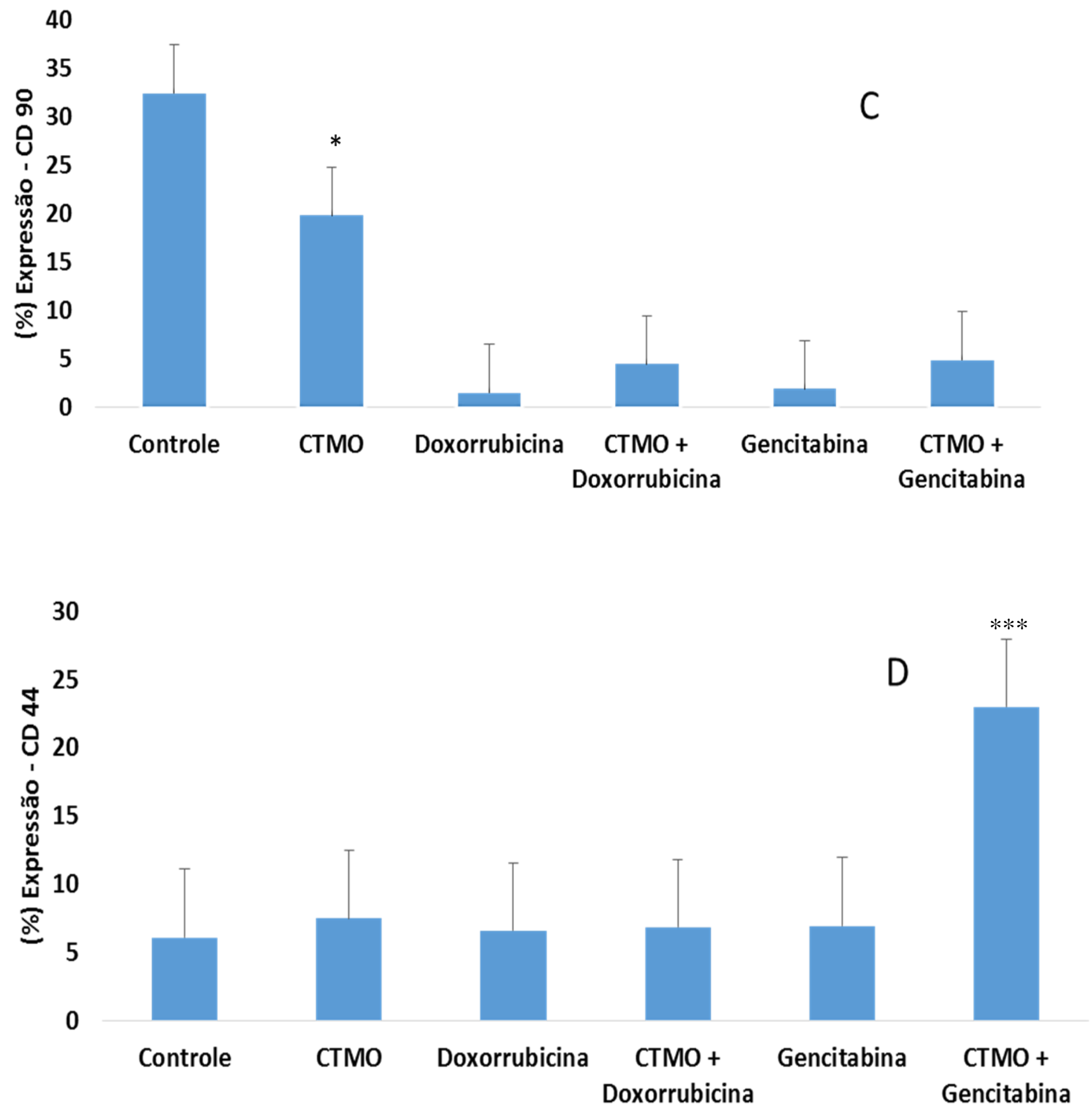


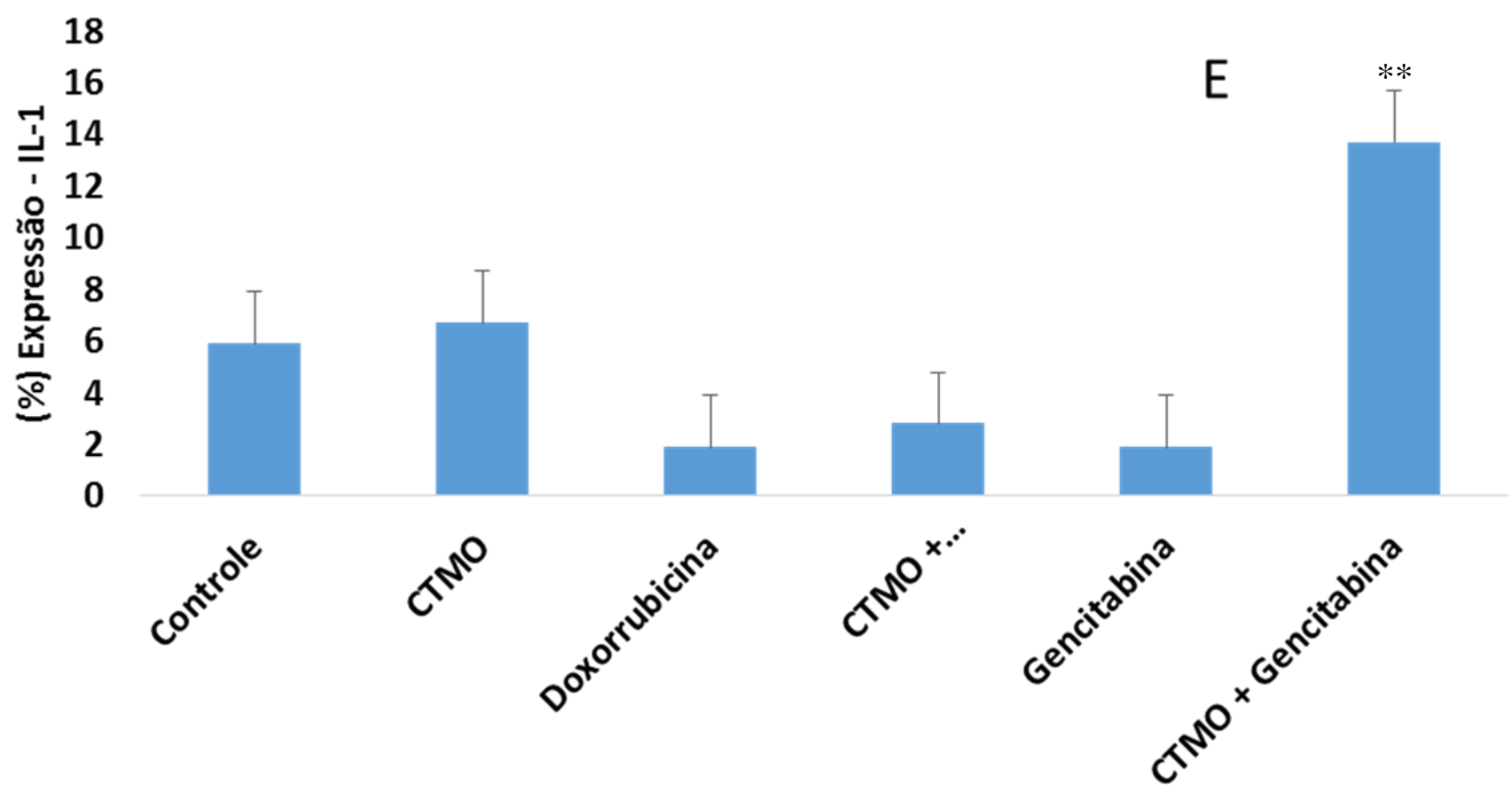

10

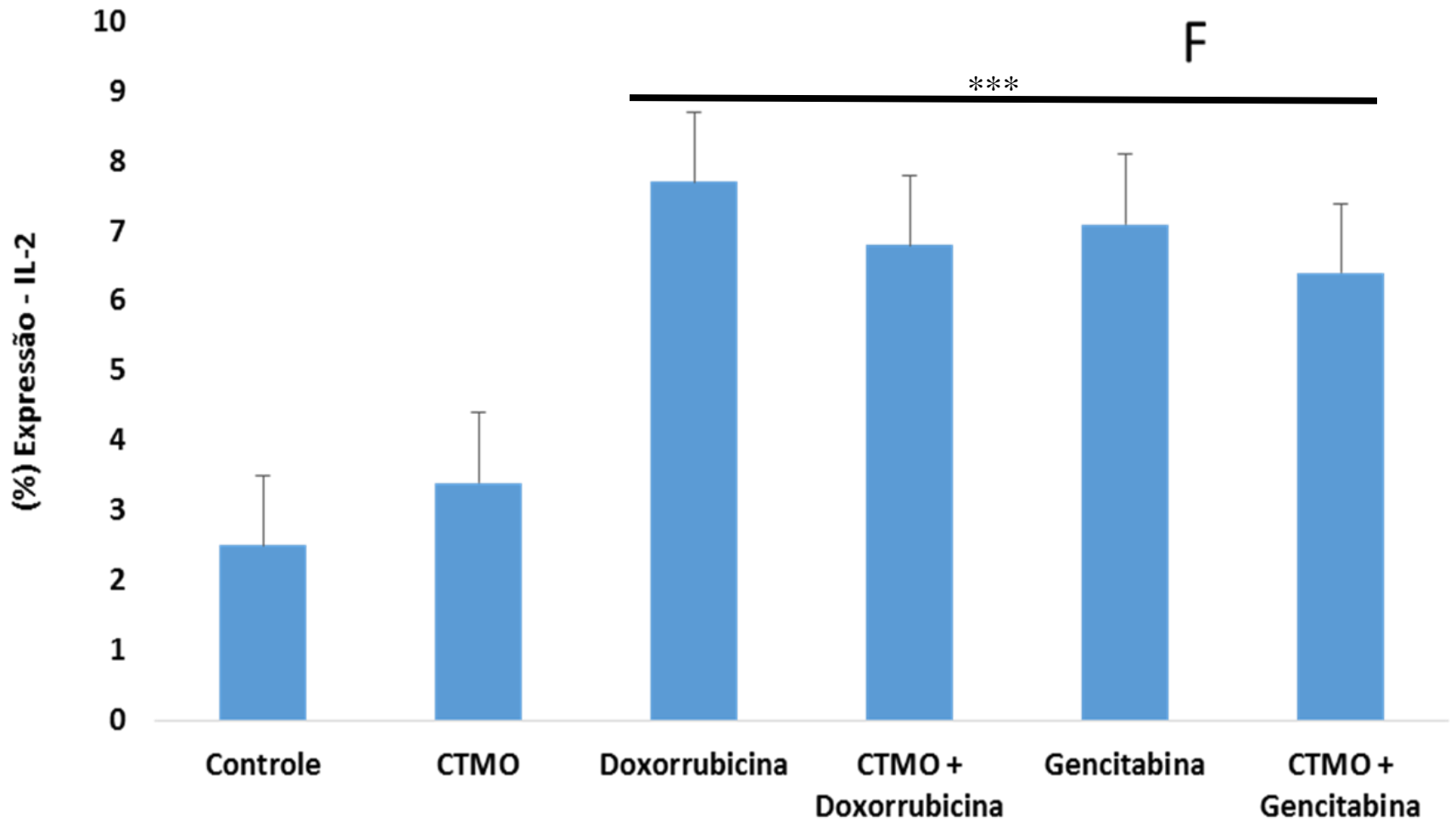


25

$* *$

G

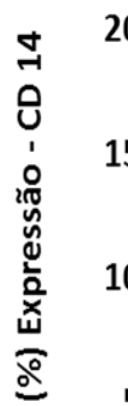

0

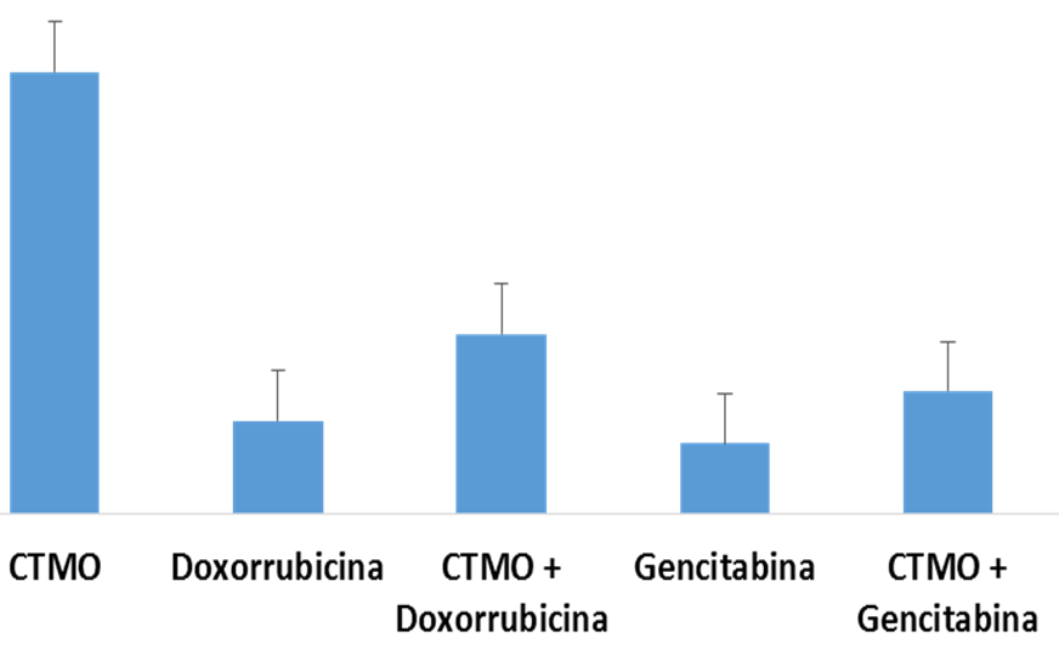

Figura 13 - Gráfico de barras das médias \pm dp da expressão dos marcadores:

A - caspase 3; B - caspase 8; C - CD90; D - CD44; E - IL1-R; F - IL2-R e G - CD14 em células tumorais obtidas da massa tumoral hepática tratadas com os quimioterápicos doxorrubicina, gencitabina, células-tronco mesenquimais e em associação a quimioterapia sistêmica. Análise estatística de variância ANOVA seguida pelo teste múltiplo de TUKEY-KRAMER. ***p<0,001 e **p<0,01. 


\subsection{Aspectos citológicos das células-tronco mesenquimais da medula óssea}

As células-tronco mesenquimais isoladas a partir da medula óssea de camundongos isogênicos C57BL/6J foram plaqueadas em meio de cultura DMEM (Dulbecco's Modified Eagle Medium) suplementado com 10\% de soro fetal bovino (SFB), 10mL/L de solução de penicilina G-estreptomicina-fungizona (1:1:1), e 2,2g de $\mathrm{NaHCO}_{3}$, a $37^{\circ} \mathrm{C}$, numa atmosfera umidificada de $5 \%$ de $\mathrm{CO}_{2}$. Após 72 horas, o meio de cultura foi substituído a fim de remover células não aderentes, obtendo-se células aderentes ao plástico e com morfologia semelhante a fibroblastos (Figura 14).
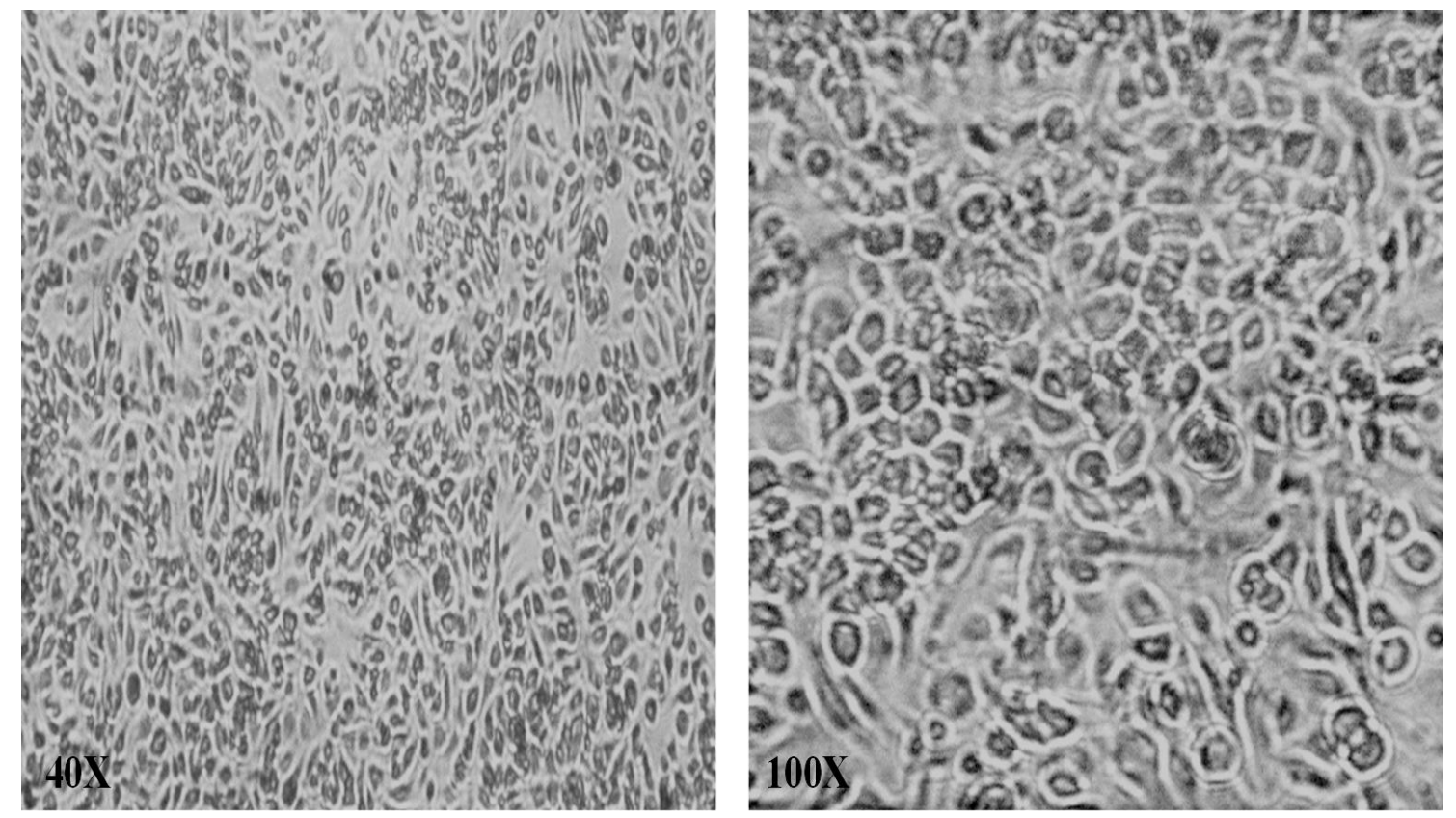

Figura 14 - Aspectos citológicos das células-tronco mesenquimais da medula óssea de camundongos C57BL/6J. Destacam-se células aderentes ao plástico e com morfologia semelhante a fibroblastos. Imagem documentada usando um microscópio invertido na ampliação (40x) mais o aumento de três vezes da aquisição digitalizada em pixels em câmera digital (100X). 


\subsubsection{Caracterização imunofenotípica das células-tronco mesenquimais da medula óssea de camundongos C57BL/6J}

Neste estudo, as células-tronco mesenquimais foram isoladas a partir da medula óssea de camundongos isogênicos C57BL/6J. Após o isolamento e cultivo das célulastronco mesenquimais, como descrito previamente no item 2.4, apresentaram-se aderentes aos frascos de cultura, morfologia semelhante à fibroblastos e expressão positiva para marcadores de células-tronco mesenquimais derivadas da medula óssea de camundongos: CD44, CD73, CD90 e CD105. Esta linhagem mostrou-se negativa para os marcadores para células-tronco hematopoiéticas da medula óssea de camundongos: CD11b, CD45 e CD117 (Figura 15), de acordo com critérios previamente estabelecidos (SCHURGERS et al., 2010; ZHUL et al., 2010).

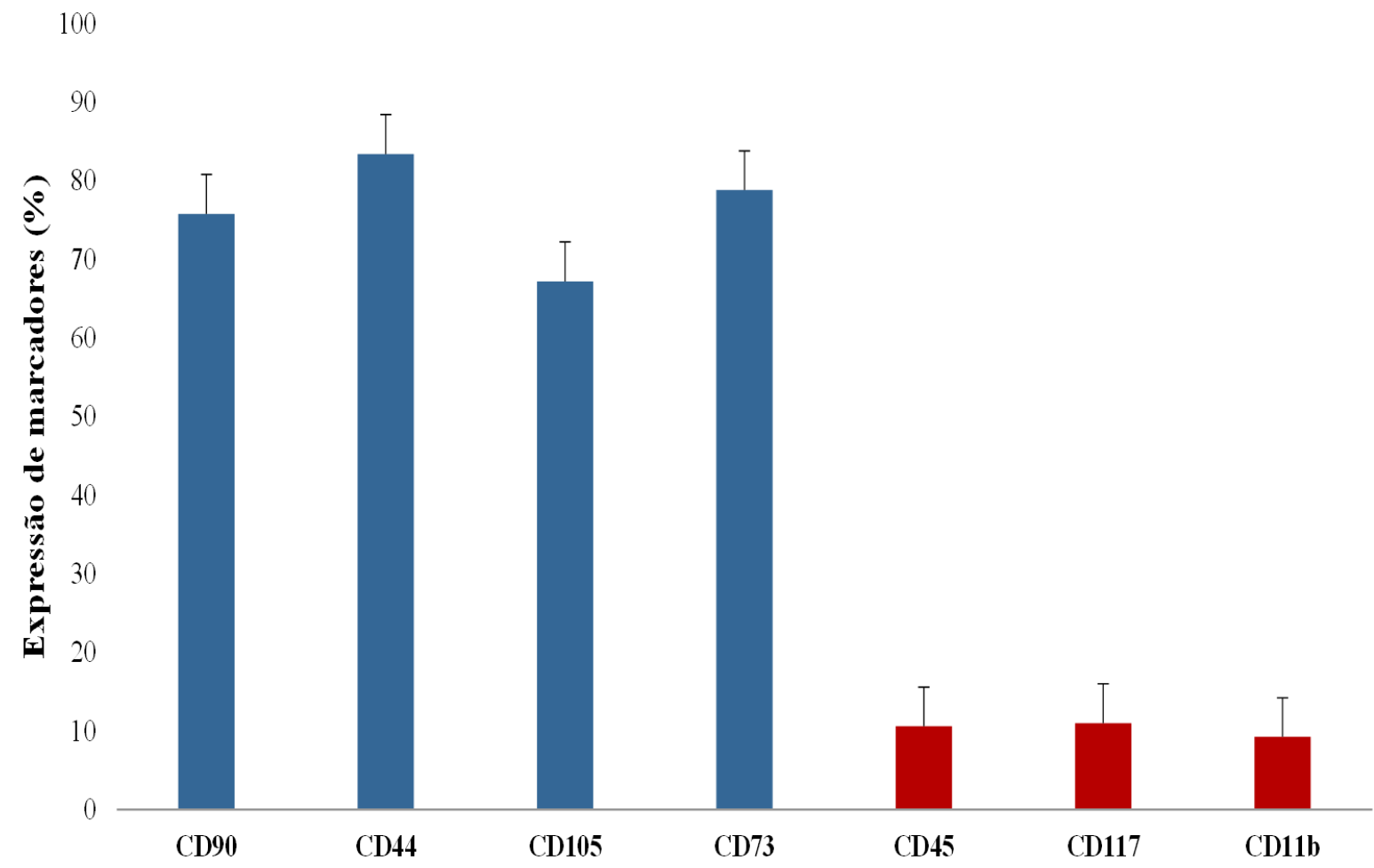

Figura 15 - Gráfico de barras das médias \pm dp da expressão dos marcadores para caracterização imunofenotípica das células-tronco mesenquimais da medula óssea de camundongos C57BL/6J. Esta linhagem mostrou-se positiva para marcadores de célulastronco mesenquimais: CD44, CD73, CD90 e CD105. Expressão negativa para os marcadores hematopoiéticas: CD11b, CD45 e CD117. 


\subsection{Análise histopatológica dos tumores e dos órgãos internos}

A análise histopatológica do parênquima dos diferentes órgãos internos do grupo tratado somente com células-tronco mesenquimais (CTM) demonstrou presença de massa tumoral hepática de aspecto nodular com a presença de células neoplásicas, nucléolos evidentes e hipercromáticos, figuras de mitose atípica na luz da veia centro lobular e preservação do parênquima hepático e raras áreas de necrose.

No espaço interalveolar do parênquima pulmonar nota-se ausência de infiltrado tumoral evidente. Parênquima esplênico com infiltrado tumoral ocasionando perda de sua arquitetura habitual, demonstrado pelo aspecto reativo dos centros germinativos. Foi possível verificar que o tratamento com CTM foi capaz de induzir morte celular nas células neoplásicas, pois há áreas de necrose e presença corpos apoptóticos. Arquitetura do parênquima renal manteve-se preservada, sem evidências de formação de massa tumoral nodular e células neoplásicas (Figura 16). 

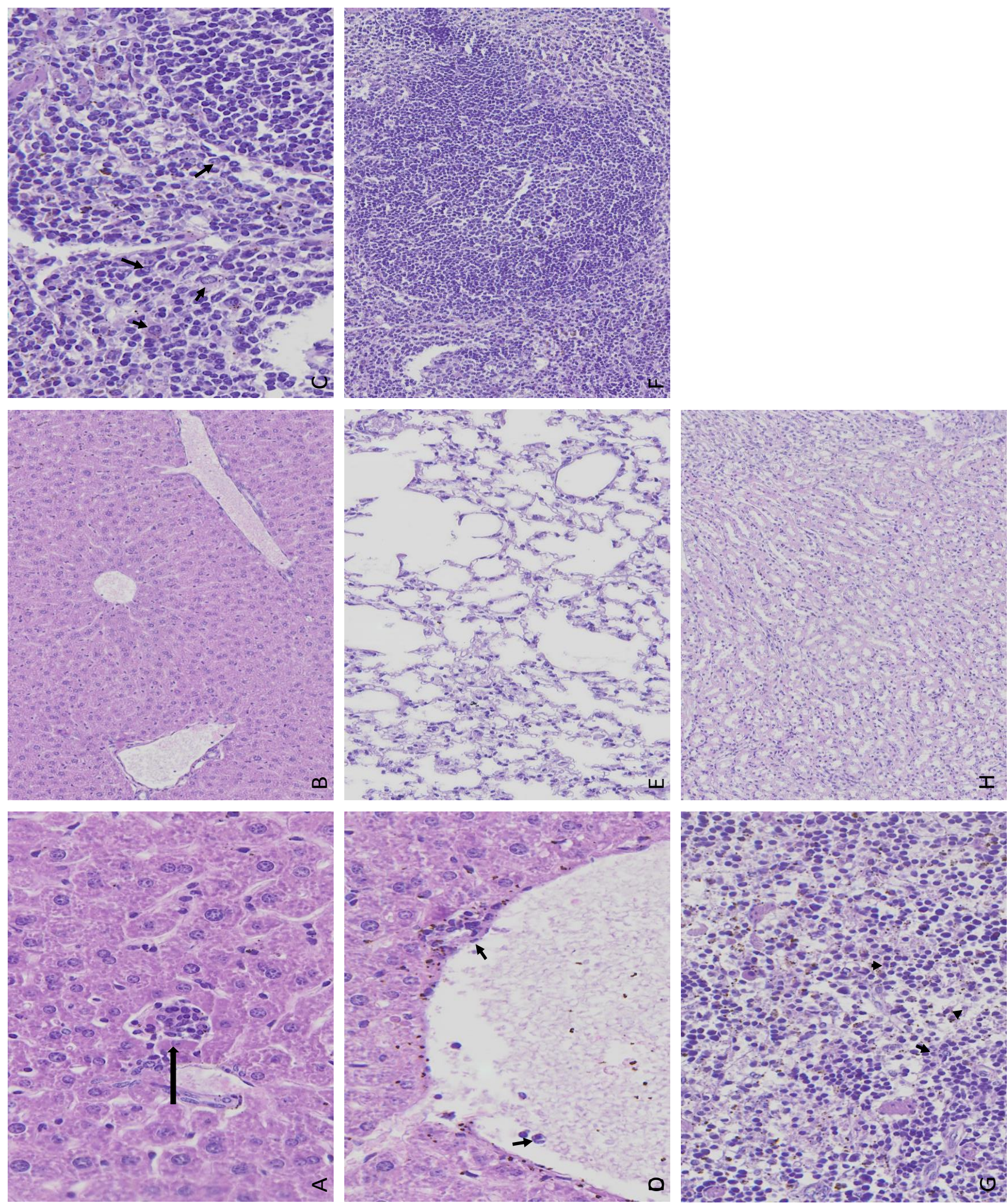
Figura 16 - Análise histopatológica de animais portadores de carcinoma hepatocelular tratados com células-tronco mesenquimais. A, B e D: presença de massa tumoral hepática de aspecto nodular (seta) com a presença de células neoplásicas, nucléolos evidentes e hipercromáticos, figuras de mitose atípica na luz da veia centro lobular (setas) e preservação do parênquima hepático e raras áreas de necrose. $\mathbf{C ,} \mathbf{F} \mathbf{e} \mathbf{G}$ : Parênquima esplênico com infiltrado tumoral ocasionando perda de sua arquitetura habitual, demonstrado pelo aspecto reativo dos centros germinativos. Foi possível verificar que o tratamento com CTM foi capaz de induzir morte celular nas células neoplásicas, pois há áreas de necrose e presença corpos apoptóticos (setas). E: No espaço interalveolar do parênquima pulmonar nota-se ausência de infiltrado tumoral evidente. H: Arquitetura do parênquima renal manteve-se preservada, sem evidências de formação de massa tumoral nodular e células neoplásicas

O grupo de tratamento com doxorrubicina apresentou alteração da arquitetura do parênquima hepático com presença de infiltrado inflamatório, raras áreas de necrose e células neoplásicas. Evidencia de raras células neoplásicas no espaço interalveolar do parênquima pulmonar. Alteração da arquitetura do parênquima esplênico, com a presença de infiltrado neoplásico. Foi evidenciado infiltrado inflamatório e neoplásico no parênquima renal, observando-se células tumorais na luz do vaso e áreas de necrose dos túbulos contorcidos (Figura 17). 

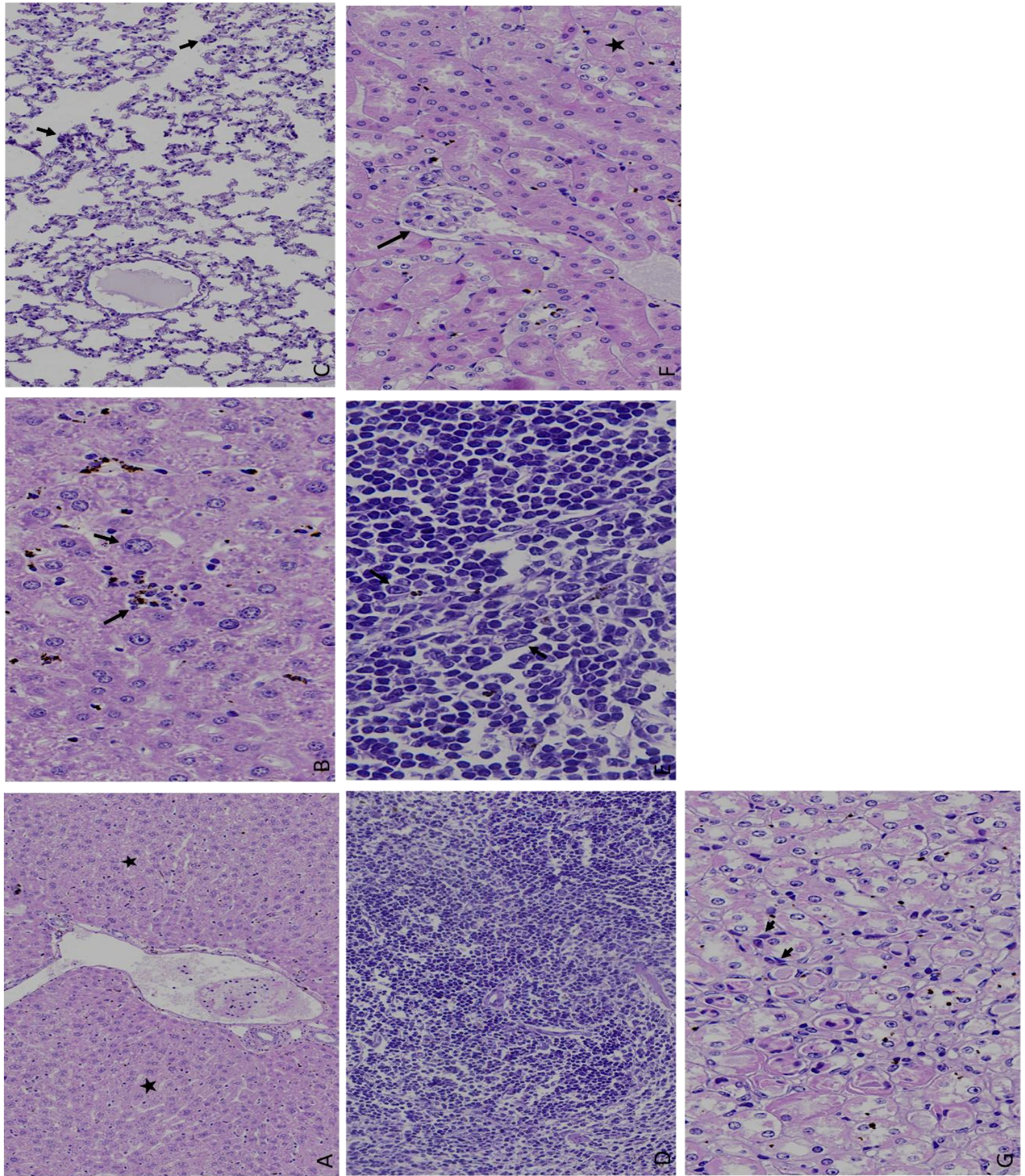
Figura 17 - Fotomicrografia da análise histopatológica de animais portadores de carcinoma hepatocelular tratados com doxorrubicina. A e B: Observa-se alteração da arquitetura do parênquima hepático com presença de infiltrado inflamatório (setas), raras áreas de necrose $(*)$ e células neoplásicas. C: Presença de raras células neoplásicas no espaço interalveolar do parênquima pulmonar (setas). D e E: Alteração da arquitetura do parênquima esplênico, com a presença de infiltrado neoplásico (setas). F e G: Infiltrado inflamatório e neoplásico no parênquima renal (setas), observando-se células tumorais na luz do vaso e áreas de necrose dos túbulos contorcidos (*).

O grupo de tratamento com doxorrubicina e células-tronco mesenquimais (CTM) apresentou preservação da arquitetura do parênquima hepático, notando-se pequenas áreas de necrose. Não sendo possível evidenciar células neoplásicas. Arquitetura do parênquima pulmonar foi preservada, no qual não foi possível a identificação de células tumorais. A presença do infiltrado tumoral esplênico foi responsável pela perda da arquitetura e arranjo do parênquima normal, demonstrado pelo aspecto reativo dos centros germinativos. Além da preservação da arquitetura do parênquima renal com raras áreas de necrose, no qual não foi possível evidenciar células neoplásicas (Figura 18). 

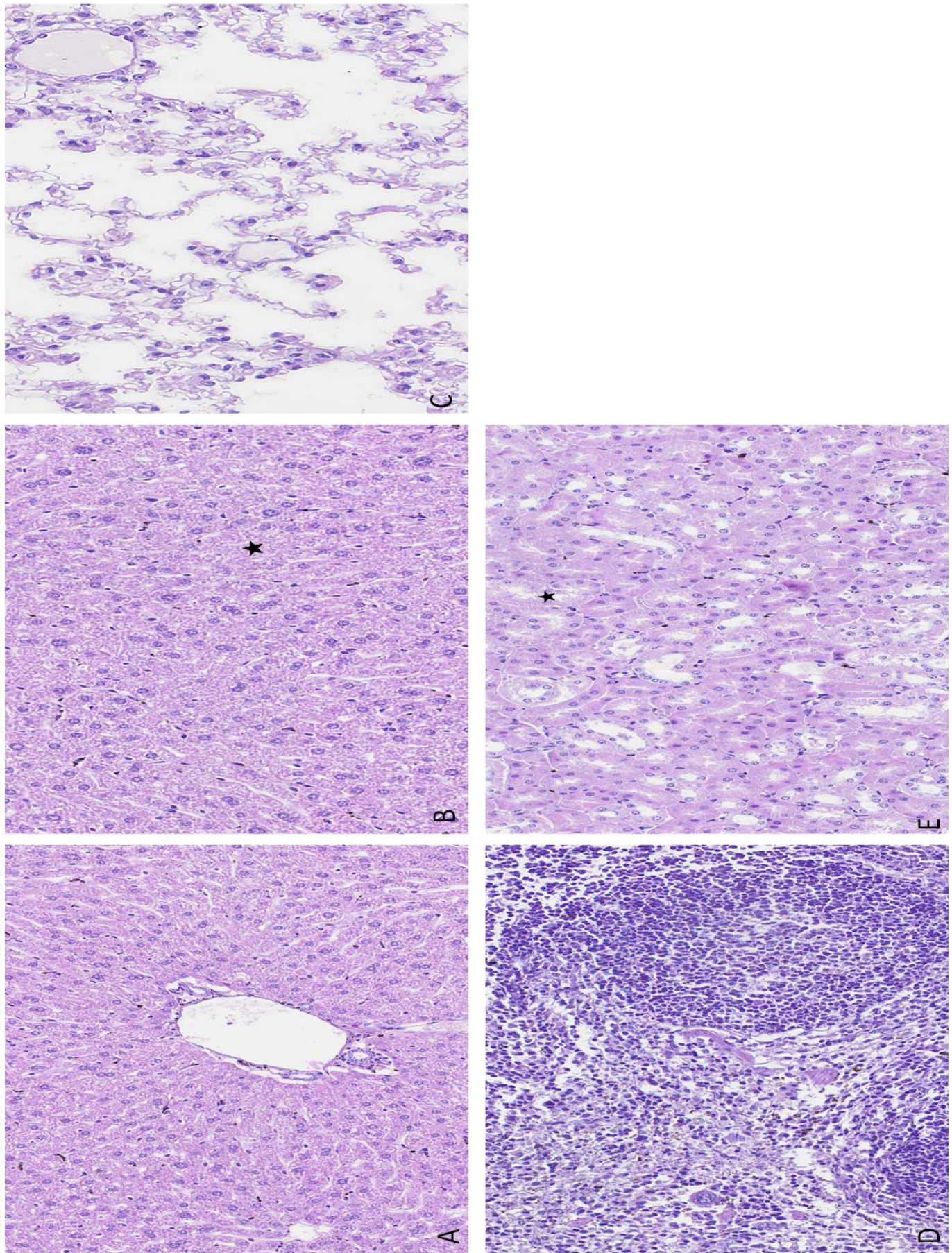

Figura 18 - Análise histopatológica de animais portadores de carcinoma hepatocelular tratados com doxorrubicina em associação com células-tronco mesenquimais. A e B: Observa-se preservação da arquitetura do parênquima hepático, notando-se pequenas áreas de necrose. (*). C: Arquitetura do parênquima pulmonar foi preservada; D: Presença de infiltrado tumoral esplênico, responsável pela perda da arquitetura e arranjo do parênquima normal, demonstrado pelo aspecto reativo dos centros germinativos. E: Notase preservação da arquitetura do parênquima renal com raras áreas de necrose (*). 
Por outro lado, o grupo tratado somente com gencitabina observa-se perda da arquitetura hepática com a presença de infiltrado inflamatório e neoplásico. Nota-se grandes áreas de necrose e formação de corpos apoptóticos. Espaço interalveolar do parênquima pulmonar congesto com áreas de necrose e perda do arranjo do parênquima pulmonar e o espaço peribrônquico com presença de áreas de necrose e células neoplásicas. Parênquima esplênico apresentou áreas de necrose e centros germinativos reativos, sem a presença de infiltrado neoplásico evidente. Presença de infiltrado neoplásico ocasionando destruição da perda da arquitetura renal (Figura 19).

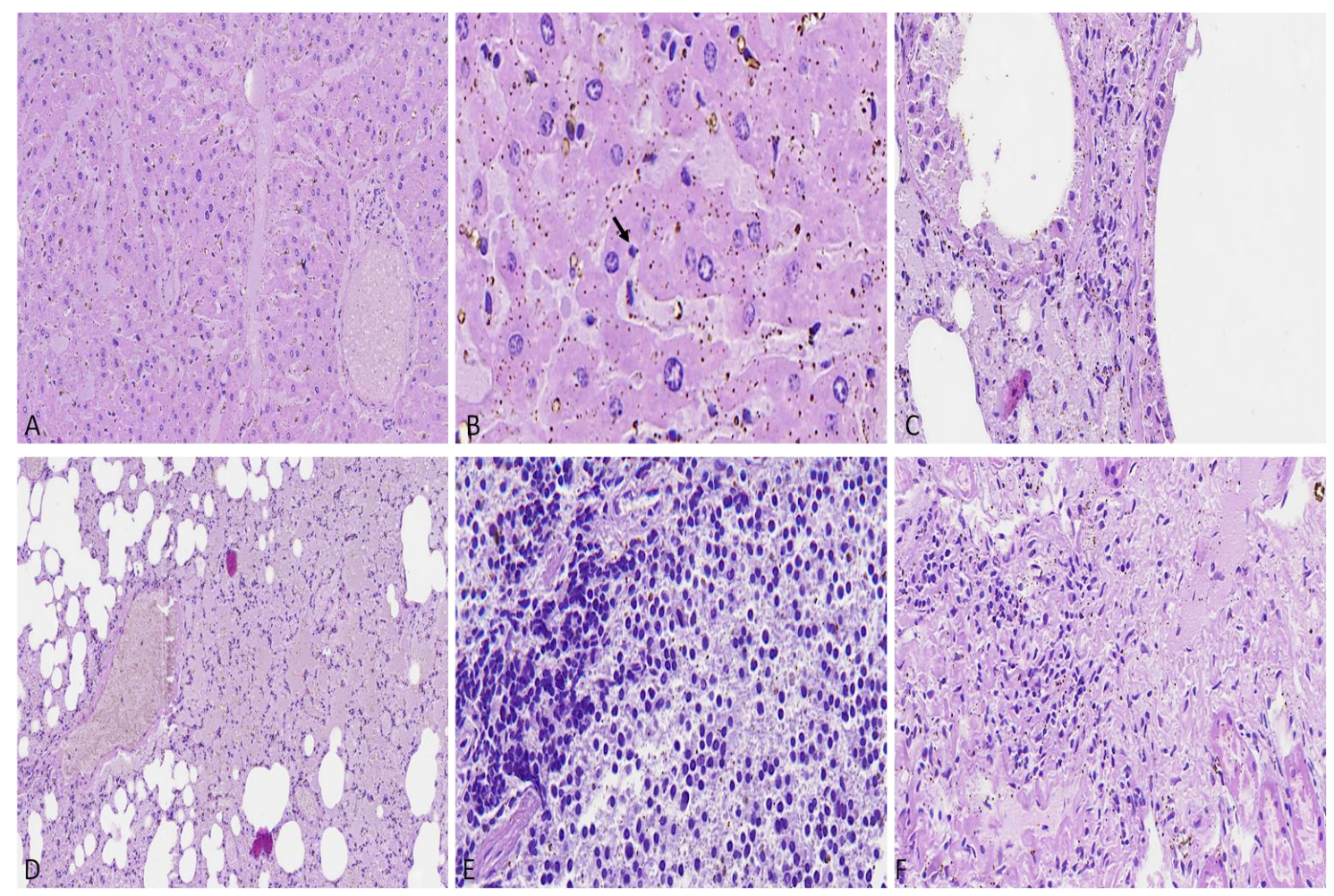

Figura 19 - Análise histopatológica dos tumores dos animais portadores de carcinoma hepatocelular tratados com gencitabina. A, B e C: Observa-se perda da arquitetura hepática com a presença de infiltrado inflamatório e neoplásico. Notam-se grandes áreas de necrose e formação de corpos apoptóticos (seta). D: Espaço interalveolar do parênquima pulmonar congesto com áreas de necrose e perda do arranjo do parênquima pulmonar e o espaço peribrônquico com presença de áreas de necrose e células neoplásicas. E: Parênquima esplênico apresentou áreas de necrose e centros germinativos reativos, sem a presença de infiltrado neoplásico evidente. F: Infiltrado neoplásico ocasionando destruição da perda da arquitetura renal. 
Em relação ao grupo tratado com gencitabina e células-tronco mesenquimais notase a perda da arquitetura do parênquima hepático, com presença de áreas de necrose, infiltrado inflamatório e corpos apoptóticos. O espaço interalveolar do parênquima pulmonar manteve-se preservado, com a presença de células neoplásicas em pequena quantidade. O parênquima esplênico apresenta áreas de necrose, sem evidência de células neoplásicas. Enquanto, o parênquima renal manteve a preservação da arquitetura, no qual não foi possível evidenciar formação de massa tumoral nodular e células neoplásicas dispersas (Figura 20).
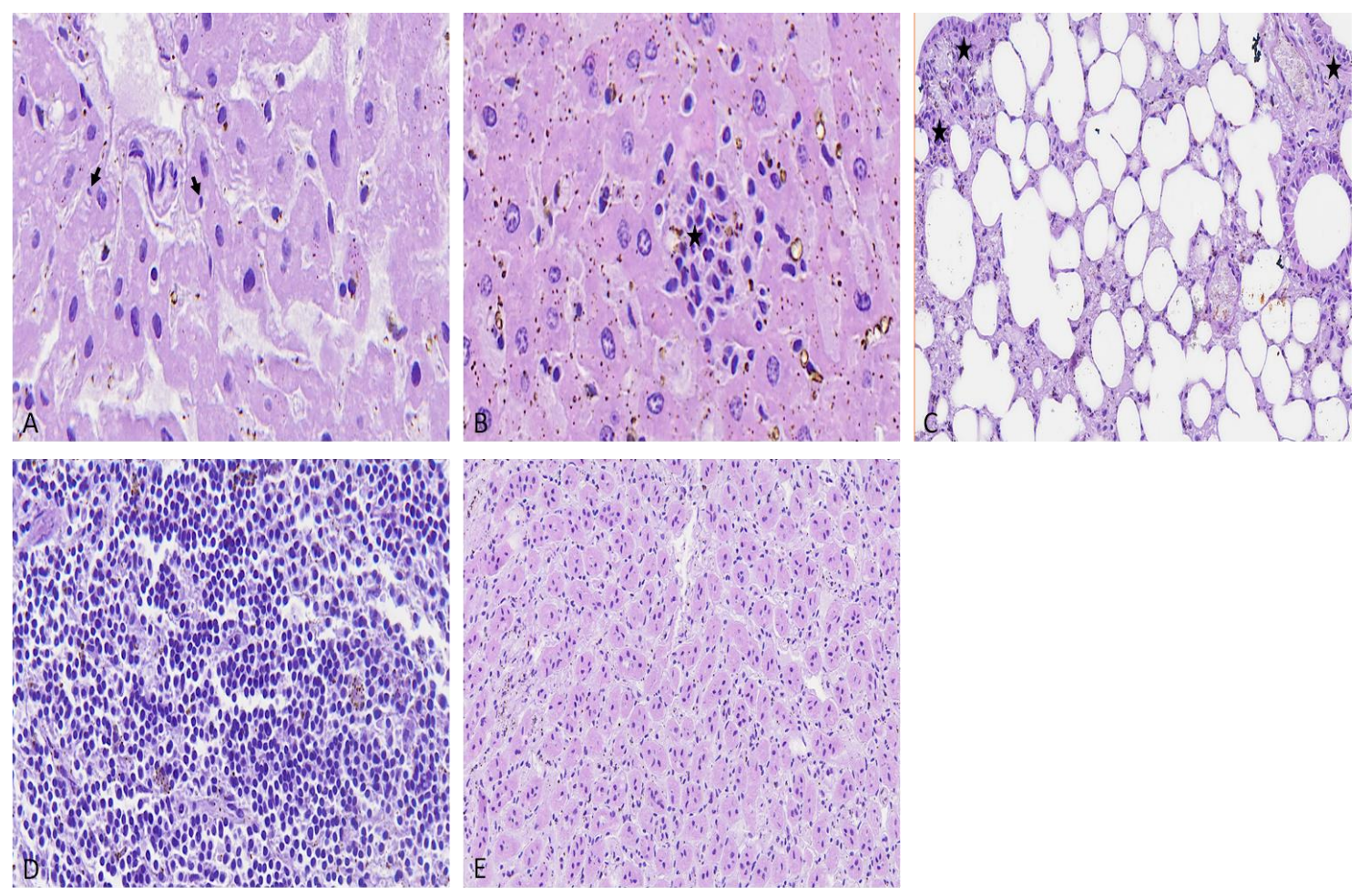

Figura 20 - Análise histopatológica dos tumores dos animais portadores de carcinoma hepatocelular tratados com gencitabina em associação com células-tronco mesenquimais. A e B: Nota-se a perda da arquitetura do parênquima hepático, com presença de áreas de necrose, infiltrado inflamatório (*) e corpos apoptóticos (setas). C: O espaço interalveolar do parênquima pulmonar manteve-se preservado, com a presença de células neoplásicas em pequena quantidade (*). D: Parênquima esplênico apresenta áreas de necrose, sem evidência de células neoplásicas. E: Parênquima renal manteve a preservação da arquitetura, no qual não foi possível evidenciar formação de massa tumoral nodular e células neoplásicas dispersas. 


\section{DISCUSSÃO}

Este estudo determinou o potencial regenerativo e imunomodulador das célulastronco mesenquimais oriundas da medula óssea de camundongos isogênicos da linhagem C57BL/6J no modelo ortotópico de carcinoma hepatocelular murino, associadas ou não aos agentes quimioterápicos (doxorrubicina e gencitabina). Além de abordar os aspectos da atenuação ou modulação dos efeitos colaterais dos agentes quimioterápicos associados à terapia celular com células-tronco mesenquimais.

A hepatocarcinogenese é um processo de passos múltiplos envolvendo diferentes alterações genéticas que conduzem finalmente à transformação maligna dos hepatócitos (FARBER, 1984). Numerosos modelos experimentais têm sido desenvolvidos para definir a patogénese do carcinoma hepatocelular e testar novas modalidades terapeuticas. Modelos animais de carcinoma hepatocelular com camundongos induzidos quimicamente imitam a evolução natural da doença, fibrose-malignidade. Seja por administração de um composto genotóxico sozinho ou, se necessário, seguido por um agente de promoção. Modelos de xenotransplante vem sendo desenvolvidos através da implantação ortotópica ou ectópica de linhagem celulares de carcinoma hepatocelular humano em camundongos; esses modelos são adequados para triagem de fármacos, embora sua extrapolação deva ser considerada com precaução, utilizando-se de múltiplas linhagens celulares.

O ensaio de fibras côncavas (hollow fibres) oferece uma solução para limitar o número de animais em experimentos de xenotransplantes por causa da capacidade para a implantação de diversas linhagens celulares. Há também uma ampla gama de animais geneticamente modificados para investigar a fisiopatologia do CHC. Os camundongos transgênicos que expressam oncogenes, genes virais e fatores de crescimento permitem a identificação de vias envolvidas na hepatocarcinogenese. Vários modelos de roedores foram utilizados para definir a patogênese atual do CHC. Por causa das semelhanças fisiológicas e genéticas entre roedores e humanos, o seu curto período de vida e sua capacidade de reprodução, os roedores são muitas vezes utilizados para a investigação das diversas neoplasias (HEINDRYCKX et al., 2009). 
O modelo de xenotransplante ortotópico é o mais adequado para a extrapolação de resultados para os seres humanos e por proporcionar informações sobre a disseminação metastática do tumor. As vantagens dos modelos de xenotransplantes em camundongos se ve ao curto espaço de tempo necessário para o desenvolvimento dos tumores e ao fato de ser uma maneira eficiente para demonstrar um modelo prático (prova de conceito) em que linhagens celulares suficientes são utilizadas. Esta técnica proporciona um modelo que permite a investigação de aspectos como a toxicidade in vivo, a absorção e a farmacocinética de um composto em um ensaio pré-clínico (HEINDRYCKX et al., 2009).

Estudos com células implantadas ortotopicamente em 30 camundongos atímicos $\mathrm{BALB} / \mathrm{c}$, resultaram na identidicação de um modelo de xenotransplante de carcinoma hepatocelular com potencial altamente metástatico (LCI-D20). O implante ortotópico de LCI-D20 leva a CHC altamente metastático, o qual apresenta várias características de comportamento inerentes ao $\mathrm{CHC}$ humano além de se assemelhar histologicamente ao carcinoma hepatocelular humano (SUN et al., 1996).

O presente estudo estabeleceu o primeiro modelo ortotópico e homológo de implantação de carcinoma hepatocelular murino, através da inoculação intra-hepática de células de carcinoma hepatocelular murino (Hepa1c1c7) a uma concentração de $10^{6}$ células tumorais em camundongos isogênicos C57BL/6J. Este modelo também reproduzui os aspectos gerais da carcinogênese hepática e de sua progressão, as metástases ocorreram em função do crescimento e disseminação das células tumorais para os diversos órgãos. Obtendo-se o estabelecimento do carcinoma hepatocelular no $21^{\circ}$ dia após a inoculação das células tumorais, pela presença na análise histopatológica de pleomorfismo celular, hepatócitos neoplásicos com citoplasma vacuolizado, áreas de necrose, infiltrado inflamatório mononuclear, dilatação sinusoidal, núcleos hipercromáticos com nucléolos proeminentes e perda da relação núcleo - citoplasma. Além da possível presença de metástases no pulmão, baço e rins.

Além do potencial em reduzir o tamanho e o volume do tumor, a quimioterapia proporciona também um papel importante na observação do comportamento biológico do tumor, tornando-se de grande importância, pois dessa maneira pode-se evitar hepatectomias em pacientes que desenvolveram metástases intra ou extra-hepáticas. 
O número limitado de doadores de fígado para transplante e a ausência de proliferação de hepatócitos em cultura são os principais fatores limitantes para terapias que envolvem o fígado e hepatócitos, respectivamente. Estas características inviabilizam a utilização destes tratamentos em grande escala. No entanto, progenitoras hepáticas são altamente expansíveis in vitro e in vivo. Estas células são capazes de proliferação extensiva e subsequente diferenciação em células do ducto biliar e em hepatócitos (MALHI et al., 2002). Tornando novas estratégias terapêuticas para o tratamento do CHC uma necessidade urgente e promissora.

As células tronco mesenquimais (CTMs) derivadas da medula óssea humana, também conhecidas como células tronco esqueléticas, células estromais da medula óssea ou, como recentemente sugerido pela International Society for Cytotherapy (ISCT) células estromais mesenquimais multipotentes, são um grupo de células clonogênicas, presentes no estroma da medula óssea, capazes de diferenciação em várias linhagens de células do tipo mesodérmico e, possivelmente, mas ainda parte de assunto controverso, em outros tipos celulares não mesodérmicos, como células neurais ou hepatócitos (ABDALLAH; KASSEM, 2009; (HORWITZ et al., 2005). Ainda de acordo com a ISCT, uma determinada população de células será classificada como célula tronco mesenquimal quando apresentar três características-chave. A primeira é que as mesmas sejam isoladas com base nas suas propriedades de adesão seletiva à superfície do material onde são cultivadas (geralmente plástica); a segunda é a expressão de determinados antígenos de membrana e, por fim, que as células possam ser diferenciadas em tecido ósseo, gorduroso e cartilaginoso após estímulo (HORWITZ et al., 2005).

A população de CTMs isoladas da medula óssea de humanos e camundongos expressa em sua superfície marcadores moleculares como: CD44 (receptor de hialuronato), CD105 (endoglina: marcador angiogênico), CD106 (VCAM-1: molécula de adesão vascular), CD166 (ALCAM: moléculas de adesão de leucócitos ativados), CD29 (integrinas VLA-B), CD73 (SH3 e SH4), CD90 (Thy1), Stro-1(estroma de suporte da hematopoese) e Sca-1 (GRONTHOS et al., 2003; KOLF et al., 2007; PHINNEY; PROCKOP, 2007). 
Neste estudo, as células-tronco mesenquimais foram isoladas a partir da medula óssea de camundongos isogênicos C57BL/6J apresentaram-se aderentes aos frascos de cultura, morfologia semelhante a fibroblastos e expressão positiva para marcadores de células-tronco mesenquimais derivadas da medula óssea de camundongos: CD44, CD73, CD90 e CD105. Esta linhagem mostrou-se negativa para os marcadores para célulastronco hematopoiéticas da medula óssea de camundongos: CD11b, CD45 e CD117, de acordo com critérios previamente estabelecidos (SCHURGERS et al., 2010; ZHUL et al., 2010).

Existe um consenso na literatura de que as CTMs não possuem marcadores típicos de células de linhagens hematopoéticas e endoteliais, como, por exemplo: CD11b (integrina Mac-1), CD14 (receptor de lipopolissacarídeo LPS), CD31 (PECAM-1), CD33 (molécula de adesão putativa de células mielomonocíticas reposnsavel pela ligação ao ácido siálico), CD34 (receptor de células endoteliais), CD133 e CD45 (presentes em todas as células hematopoéticas). Sendo assim, a ausência dos antígenos CD14, CD34 e CD45 na superfície dessas células mesenquimais permite distingui-las das precursoras hematopoéticas. Embora já tenham sido identificados oito marcadores de superfície para identificação de MSC, a ISCT concorda que apenas a identificação dos marcadores CD105, CD73 e CD90, quando não estiverem expressos marcadores hematopoéticos, é suficiente para a caracterização imunofenótipa dessas células. Contudo, essa caracterização deve sempre estar acompanhada da demonstração da aderência celular por longos períodos em cultura e da diferenciação destas em pelo menos duas linhagens celulares distintas (HORWITZ et al., 2005).

Neste estudo, a citotoxicidade foi avaliada pelo método colorimétrico MTT para determinação das concentrações inibidoras $\mathrm{IC}_{50} \%$ da linhagem de carcinoma hepatocelular murino (Hepa1c1c7). O tratamento desta linhagem celular com os quimioterápicos doxorrubicina e gencitabina, resultou num valor de $\mathrm{IC}_{50}$ altamente significativa à uma concentração de $1,85 \mu \mathrm{M}$ para a doxorubicina e $20,8 \mu \mathrm{M}$ para a gencitabina; demonstrando maior sensibilidade dessas células à doxorrubicina.

Embora a farmacologia destes quimioterápicos (doxorrubicina e gencitabina) já esteja estabelecida, as culturas celulares são essenciais para a obtenção de informações sobre os efeitos dos fármacos quimioterápicos que alteram a cinética de proliferação celular. 
Diluições semelhantes foram utilizadas num estudo anterior para o tratamento de carcinoma hepatocelular (células tumorais primárias 2-1318, 5-1318, e 26-100) com doxorrubicina $(0,17 \mu \mathrm{M}$ a 3,4 $\mu \mathrm{M})$, durante 24 horas, obtendo-se concentração inibitória $\mathrm{IC}_{50}$ de 3,37 $\mu \mathrm{M}$ (HUYNH et al., 2007). Além de se obter concentrações inibitórias $\mathrm{IC}_{50}$ semelhantes as obtidas neste estudo para o tratamento dos animais portadores de carcinoma hepatocular, $(4,4 \mu \mathrm{M})$ em linhagem celular de carcinoma hepatocelular humano (HepG2), após 72 horas de tratamento (WEI, 2011). Em relação ao tratamento da linhagem de carcinoma hepatocelular murino (Hepac1c1c7) com o quimioterápico gencitabina, utilizou-se diluições a partir de valores de IC $_{50}$ semelhantes $(23,9 \mu \mathrm{M}, 830$ $\mathrm{nM}, 494 \mathrm{nM}$ e 9,5 $\mu \mathrm{M})$, resultados obtidos em linhagens celulares de carcinoma de pâncreas (AsPC- 1, BxPC-3, MIA PaCa-2 e Panc-1), respectivamente (AWASTHI et al., 2013); corroborando com os dados obtidos neste estudo.

TBARS quantifica a formação do malondialdeido, um dos principais produtos de decomposição dos hidroperóxidos de ácidos graxos poliinsaturados, formados durante o processo oxidativo. A reação destas espécies com os ácidos graxos poliinsaturados presentes nas membranas celulares e nas lipoproteínas iniciam um processo em cadeia conhecido como peroxidação lipídica ou lipoperoxidação (LPO). A LPO pode ser definida como uma cascata de eventos bioquímicos resultante da ação dos radicais livres sobre os lipídeos insaturados das membranas celulares, levando à destruição de sua estrtutura, falencia dos mecanismos de troca de metabólitos e, numa condição extrema, à morte celular (BENZIE, 1996). A LPO pode ser indicada como um dos eventos citotóxicos primários que desencadeia sequência de lesões na célula.

O tratamento da linhagem de carcinoma hepatocelular murino (Hepa1c1c7) com os compostos quimioterapêuticos (doxorrubicina e gencitabina) resultou em um aumento significativo na quantidade de danos as membranas celulares a partir de concentrações de 55 a $250 \mu \mathrm{M}$ (doxorrubicina) e 218,75 a $7000 \mu \mathrm{M}$ (gencitabina).

A avaliação da distribuição das fases das células ao longo do ciclo celular foi realizada através da incorporação de iodeto de propídeo, um fluorocromo que se intercala estequiometricamente a cada quatro pares de bases de DNA. 
Foi utilizada uma solução contendo iodeto de propídeo e RNAse, necessária para degradação do RNA presente (OTAKE, 2005). Ambas as modalidades terapêuticas apresentaram resultados semelhantes, tais como o aumento da população de células em fase sub-G1 e G0/G1. Além de induzir significativamente diminuição da população celular nas fases $\mathrm{S}$ e G2/M.

A doxorrubicina é um agente não específico do ciclo celular, atuando tanto nas células em fase de divisão quanto nas células em repouso. No entanto, sua principal ação citotóxica é observada durante a fase S do ciclo celular (SUSANECK, 1983; RODASKI; DE NARDI, 2008). Em relação ao mecanismo de ação, as antraciclinas agem alterando o DNA e produzindo radicais livres, por isso são eficazes contra o câncer.

A gencitabina (2,2-difluorodeoxicitidina) é sintetizada como um análogo da citarabina. Este fármaco é classificado como específico para a fase $\mathrm{S}$ do ciclo celular. Inibe a síntese de DNA e bloqueia a progressão das células em fase G1/S (PLUNKETT, 1995).

Após o tratamento com CTM oriundas da medula óssea associada ou não a quimioterapia sistêmica foi observada aspectos significativos na redução da massa tumoral após o tratamento com CTM (30,5\%), entretanto foi possível evidenciar nos demais grupos experimentais tratados com quimioterapia sistêmica associada à terapia celular resultados significativos além de se observar atenuação dos efeitos colaterais sistêmicos. Através da modulação dos efeitos imunossupressores provocados pelo tratamento quimioterápico e intensificação dos efeitos imunomoduladores provenientes da terapia celular com CTM da medula óssea, pela regulação de moléculas pró e anti apoptóticas. Evidenciado em nosso estudo pelo aumento da expressão (caspase 3 e 8, CD44 e IL-1R) no grupo de animais tratados com CTM em associação ao quimioterápico gencitabina e aumento na expressão (CD90 e CD14) no grupo de animais tratados somente com CTM.

A distribuição nas fases do ciclo celular encontra-se significativamente na fase sub-G1 nos grupos de animais tratados com CTM em associação ao quimioterápico gencitabina e doxorrubicina $(39,14 \%$ e $30,14 \%)$ respectivamente, doxorrubicina $(26,14 \%)$ e gencitabina $(19,84 \%)$ além de induzir significativamente diminuição das fases $\mathrm{S}$ e $\mathrm{G} 2 / \mathrm{M}$. 
A supressão mediada pelas CTM é produzida através de seu efeito antiproliferativo, resultado da secreção de uma variedade de citocinas que induzem a parada do ciclo celular em linhagens de células tumorais, embora de forma transiente, nas fases iniciais G0/G1, ocasionando redução da proliferação celular (COUSIN et al., 2009; LU et al., 2008).

As células-tronco no fígado apresentam duas origens: endógenas ou exógenas intra ou extra-hepáticos. No compartimento de células tronco intra-hepática denominadas de PAP estão em maior em número com capacidade proliferativa de curto prazo. Por outro lado, as células precurssoras HPC estão localizadas no interor dos canais de Hering e nos ductos interlobulares biliares. No compartimento das células tronco extra-hepática células derivadas da medula óssea e células do sangue periférico; são células em menor número, mas com capacidade de proliferação a longo prazo (WANG et al., 2010; TURNER et al., 2011; BRILL et al., 1993; NAVARRO-ALVAREZ et al., 2010; ALISON; LOVELL, 2005). Um dos principais alvos de pesquisas, já em desenvolvimento, com células-tronco encontra-se na área de oncologia. A utilização de células-tronco, nestes casos, estaria relacionada com a reconstrução dos tecidos. Há evidências que sugerem que as célulastronco mesenquimais (CTMs) têm a tendência a acumular-se nos tecidos tumorais. No modelo de melanoma, pesquisadores demonstraram que as células-tronco mesenquimais doadoras preferencialmente acumulam-se em locais de tumores (STUDENY et al., 2002). Beckermann et al (2008) demonstraram que as células-tronco mesenquimais dominantemente residem nos tecidos dos tumores pancreáticos. As células-tronco mesenquimais podem inibir o crescimento do tumor através de múltiplos mecanismos. Os resultados de um conjunto de ensaios in vitro demonstraram que as CTMs poderiam inibir a proliferação das células tumorais e aumentar a apoptose. Qiao et al (2008) relataram que, na presença de CTMs, a expressão de c-myc, Bcl-2 e antígeno de proliferação celular (PCNA) em células de hepatocarcinoma humano foi regulada negativamente, o que leva a uma reduzida taxa de proliferação das células tumorais e aumento da apoptose. Outros estudos relatam que a inoculação de células-tronco mesenquimais derivadas da medula óssea podem estimular a regeneração hepática e restaurar a função do fígado durante a lesão hepática crónica através do aumento da degradação da fibrose hepática em ratos (SAKAIDA et al, 2004;. UENO, 2006). Tais eventos estão associados com a indução de metaloproteinases (MMPs), especialmente as MMPs 2, 9, e 13 (HIGASHIYAMA, 2007). 
Assim, o papel das células-tronco mesenquimais na regeneração hepática pode ser favorável na geração de um novo parênquima e, em algumas circunstâncias, na melhoria da fibrose hepática. Mecanismos semelhantes foram relatados em camundongos, resultando na melhoria da função cardíaca após o transplante de células de medula óssea (FAZEL et al., 2006). Além disso, foi demonstrado in vivo a capacidade destas células em promover reparação tecidual após dano hepático (AURICH et al., 2009; BANAS et al., 2008).

As CTM produzirem um grande número de citocinas, dentre elas, LIF (leukemia inhibitory factor), SCF (stem cell factor), SDF-1 (stromal derived factor), oncostatina M (oSM), BMP-4 (bone morphogenetic protein-4), ligante Flt-3 da tirosina kinase (Flt-3 lig) e o TGF $\beta$. Também produzem uma grande variedade de interleucinas (IL), como: IL-1, IL-6, IL-7, IL-8, IL-11, IL-12, IL-14 e IL-15. Quando cultivadas na presença da IL-1 $\alpha$, as CTM produzem citocinas que agem nos progenitores hematopoiéticos mais maduros, como a TPo (thrombopoietin), o GM-CSF (granulocyte macrophage colony-stimulating factor), o G-CSF (granulocyte colony stimulating factor), o M-CSF (macrophage colonystimulating factor) (DAZZI el al., 2006). Tornando-se candidatas ideais para os protocolos da medicina regenerativa.

A observação de que o progresso de tumores em doentes com $\mathrm{CHC}$, apesar da presença de respostas imunitárias específicas do tumor sugere que o desenvolvimento de CHC conduz a um número de mecanismo imunossupressor, que são importantes a ser considerado ao conceber protocolos de imunoterapia. Estes mecanismos incluem a produção de citocinas imunossupressoras, tais como TGF- $\beta$ e prostaglandinas, as células apresentadoras de antígeno com deficiência, a geração de macrófagos inibidoras, aumento de células $\mathrm{T}$ reguladoras e de indução de células supressoras derivadas de mielóides. Todos estes fatores proporcionam um ambiente que promove a angiogênese, a sobrevivência do tumor e metástases.

Segmentação de células $\mathrm{T}$ reguladoras tem sido de grande interesse para, potencialmente, remova a supressão de células T efetoras e melhorar a resposta imunitária específica para o tumor. A depleção de células $\mathrm{T}$ reguladoras, utilizando anti-CD25 anticorpos monoclonais ou agentes de inibição de células $\mathrm{T}$ reguladoras, tais como a ciclofosfamida, tem sido demonstrado ter efeitos antitumorais em modelos pré-clínicos. 
Além disso, MDSC suprimir a produção de citocinas, bem como a capacidade citotóxica das células assassinas naturais (NK), desempenhando um papel crítico na defesa do hospedeiro contra o cancro, em doentes com CHC. Diminuição das células NK podem afetar as respostas imunitárias antitumorais, o que contribui ainda mais para a fuga do tumor a partir de ambas as respostas imune inata e adaptativa em doentes com CHC (GHIRINGHELLI et al., 2004; HOECHST et al., 2009).

Em nosso estudo os efeitos imunomodulatórios no grupo tratado com o quimioterápico gencitabina e CTM há um aumento da expressão de moléculas envolvidas na apoptose e de marcadores de remodelamento tecidual e da reposta imunológica como o CD44 e a IL-1B, enquanto os efeitos do tratamento isolado com CTM resultou no aumento na expressão dos marcadores CD90 e CD14.

As modificações na expressão do CD44 durante as respostas inflamatórias é um marcador da progressão do tumor. Tumores de origem epitelial que expressão isoformas da CD44 são específicas para determinados tipos de tumores, porém com um significado ainda não esclarecido, aparentemente relacionado auto-renovação. CD44 apresenta mais de 20 isoformas gerando diferentes splicing alternativos. No entanto, ainda há incerteza sobre o mecanismo exato pelo qual CD44 participam no controle do crescimento do tumor ou no perfil da resposta inflamatória (NAWWAF, BASAKRAM, 2015).

O CD44 é um receptor glicoproteico que é ativado pela ao ácido hialurônico. Em células tronco hematopoiéticas, CD44 modula a migração destas células da medula óssea. $\mathrm{O}$ fator de crescimento derivado das plaquetas estimula as células-tronco mesenquimais para produzirem CD44 que o facilita a sua ligação extracelular ao ácido hialurônico. Este processo é sugerido para auxiliar no recrutamento das CTM durante o desenvolvimento e regeneração tecidual do tecido e especificamente de forma intrínseca em diferentes nichos (WILLIAMS, et al., 2013). 
O marcador CD90 funciona como um importante regulador da interação célula com célula e de células à matriz extracelular, apoptose, adesão, migração, tumor e fibrose (REGE et al., 2006). O CD90 é também expresso em células tronco derivadas da medula óssea, células tronco hepáticas e progenitoras, tanto em adultos ou fígados fetais, mas não em hepatócitos adultos. As células que apresentam o fenótipo CD90 + CD44 + CD29 + $\mathrm{CD}{ }^{+}$isoladas do fígado adulto normal mostram diferenciação potencial osteogênico e endoteliais, e também podem induzido a formação de estruturas tipo de ilhotas pancreáticas (DENNIS et al., 2007; HERRERA et al., 2006; DAN et al., 2006; LÁZARO et al., 2003).

Nossos dados mostraram a modulação na expressão de CD90, CD73 e negativos para o marcador CD45, nos grupos de animais tratados com CTM e também nos tratamentos associados CTM doxorrubicina e gencitabina, em particular remodelando a presença de necrose.

As falhas nos tratamentos de pacientes com carcinoma hepatocelular são atribuídas à recorrência da doença após o tratamento curativo e a resistência de células de carcinoma hepatocelular a quimioterapia convencional, o que pode ser explicado em parte pela função de células-tronco tumorais no parênquima hepático ou mesmo seus efeitos imunomoduladores. Em particular, as células-tronco e derivadas de tecidos de adultos podem ser não só uma fonte de células para terapias regenerativas autólogas, mas também no estudo de mecanismos envolvidos na fisiopatologia, bem como no delineamento de novas drogas, em experimentos de toxicidade. Outro ponto importante, nesse processo e o desenvolvimento de biomateriais que favoreçam a proliferação, adesão, diferenciação e remodelação de estruturas ou tecidos danificados.

Além disso, ao se descreverem os mecanismos de diferenciação de células-tronco adultas, estes poderão auxiliar em protocolos para trans-diferenciação celular, ou seja, obtenção de células de interesse a partir de células já diferenciadas, que poderão de maneira efetiva substituir a função do órgão ou tecido lesado. Ficou evidente o papel imunomodulador sobre os efeitos imunossupressores dos quimioterápicos no modelo de hepatocarcinoma proposto neste trabalho. 


\section{CONCLUSÃO}

Neste estudo foi estabelecido o modelo ortotópico de hepatocarcinoma em camundongos C57BL/6J, o que permitiu avaliar os seguintes aspectos da terapia celular com células tronco associada ao esquema quimioterápico:

- A administração das células tronco mesenquimais da medula óssea foi eficaz na redução da massa tumoral e atenuação dos efeitos imunossupressores isoladamente ou mesmo quando associadas aos quimioterápicos;

- Células tronco mesenquimais apresentaram efeitos imunomoduladores no crescimento do hepatocarcinoma;

- A eficácia na regulação de moléculas/receptores envolvidas na indução de apoptose e no controle do crescimento e progressão tumoral, foi comprovada pela administração das células tronco mesenquimais, neste modelo experimental de hepatocarcinogênese. 


\section{REFERÊNCIAS}

ABDALLAH, B.M.; KASSEM, M. The use of mesenchymal (skeletal) stem cells for treatment of degenerative diseases: current status and future perspectives. Journal of Cellular Physiology, v. 218, n. 1, p. 9-12, 2009.

ALISON, M.R.; LOVELL, M.J. Liver cancer: the role of stem cells. Cell Proliferation, v. 28, p. 407-421, 2005.

ALLEN, K.J.; BUCK, N.E.; WILLIAMSON, R. Stem cells for treatment of liver disease. Transplant Immunology, v. 15, p. 99-112, 2005.

ALMEIDA, V. L.; LEITÃO, A.; REINA, L. D. C. B.; MONTANARI, C. A., DONNICI, C. L. Câncer e agentes antineoplásicos ciclo-celular específicos e ciclocelular não específicos que interagem com o DNA: uma introdução. Química Nova, São Paulo, v. 28, n. 1, p. 118-129, 2005.

AURICH, I.; MUELLER, L.P.; AURICH, H.; LUETZKENDORF, J.; TISLJAR, K.; DOLLINGER, M.M.; SCHORMANN, W.; WALLDORF, J.; HENGSTLER, J.G.; FLEIG, W.E.; CHRIST, B. Functional integration of hepatocytes derived from human mesenchymal stem cells into mouse livers. Gut, v. 56, n. 3, p. 405-415, 2007

AWASTHI, N.; ZHANG, C.; SCHWARZ, A. M.; HINZ, S.; WANG, C.; WILLIAMS, N. S.; SCHWARZ, M. A.; SCHWARZ, R. E. Comparative benefits of Nab-paclitaxel over gemcitabine or polysorbate-based docetaxel in experimental pancreatic cancer. Carcinogenesis, v. 34, n. 1, p. 2361-2369, 2013. 
BANAS, A.; TERATANI, T.; YAMAMOTO, Y.; TOKUHARA, M.; 3. TAKESHITA, F.; OSAKI, M.; KATO, T.; OKOCHI, H.; OCHIYA, T. Rapid hepatic fate specification of adipose-derived stem cells and their therapeutic potential for liver failure. Journal of Gastroenterology and Hepatology, v. 24, n. 1, p. 70-77, 2009.

BARBARA, L.; BENZI, G.; GAIANI, S.; FUSCONI, F.; ZIRONI, G,; SIRINGO, S,; RIGAMONTI, A.; BARBARA, G.; GRIGIONI, W.; MAZZIOTTI, A.; BOLONDI, L. Natural history of small untreated hepatocellular carcinoma in cirrhosis: a multivariate analysis of prognostic factors of tumor growth rate and patient survival. Hepatology, v. 16, p. 132-137, 1996.

BECKER, A. J.; MC, C. E.; TILL, J. E. Cytological demonstration of the clonal nature of spleen colonies derived from transplanted mouse marrow cells. Nature, p. 452-454, 1963.

BECKERMANN, B. M.; KALLIFATIDIS, G.; GROTH, A.; FROMMHOLD, D.; APEL, A.; MATTERM, J. VEGF expression by mesenchymal stem cells contributes to angiogenesis in pancreatic carcinoma. British Journal of Cancer, v. 99, n. 4, p. 622$631,2008$.

BEN, Z.S. Cellular Homeostasis and Repair in the Mammalian Liver. Annual Review of Physiology, v. 77, p. 179-200, 2015.

BENZIE, I.F.F. Lipid peroxidation: a review of causes, consequences, measurements and dietary influences. International Journal of Food Sciences and Nutrition, v.47, p. 233$261,1996$.

BIANCO, P.; KUZNETSOV, S. A.; RIMINUCCI, M.; GEHRON, R.P. Postnatal skeletal stem cells. Methods in Enzymology, v. 419, p. 117-148, 2006. 
BIONDO-SIMÕES, M.L.P.; GRECA, F.; SMANIOTTO, G.H.; TECHY, F.; SOARES, D.P.; KANNENBERG, C.; CASTRO, C.C.L.; VASCONCELOS, C.N. Efeito da histamina na regeneração hepática: estudo experimental em ratos. Acta Cirúrgica Brasileira, v. 15, n. 1, p. 9-13, 2000.

BLACK, D.; LYMAN, S.; HEIDER, R.; BEHRNS, K.E. Molecular and cellular features of hepatic regeneration. Journal of Surgical Research, v. 117, n. 2, p. 306-315, 2004.

BLAZER, D. G.; KISHI, Y.; MARU, D. M.; KOPETZ, S.; CHUN, Y. S.; OVERMAN, M. J.; FOGELMAN, D.; ENG, C.; CHANG, D. Z.; WANG, H.; ZORZI, D.; RIBERO, D.; ELLIS, L. M.; GLOVER, K. Y.; WOLFF, R. A.; CURLEY, S. A.; ABDALLA, E. K.; VAUTHEY, J. N. Pathologic response to preoperative chemotherapy: A new outcome end point after resection of hepatic colorectal metastases. Journal of Clinical Oncology, v. 26, p. 5344-5351, 2008.

BLENOIST, S.; NORDLINGER, B. Neoadjuvant treatment before resection of liver metastases. European Journal of Surgical Oncology, v. 33, n. 2, p. 35-41, 2007.

BODLEY, A.; ISRAELI, M,R.; SESHADRI, Y.; KOSEKI, FC.; GIULIANI, S.; KIRSCHENBAUM, R.; SILBER, M. Potmesil DNA topoisomerase II-mediated interaction of doxorubicin and daunorubicin congeners with DNA. Cancer Research, v. 49, p. 5969-5978, 1989.

BOSSOLASCO, P.; MONTEMURRO, T.; COVA, L.; ZANGROSSI, S.; CALZAROSSA, C.; BUIATIOTIS, S.; SOLIGO, D.; BOSARI, S.; SILANI, V.; DELILIERS, G. L.; REBULlA, P.; LAZZARI, L. Molecular and phenotypic characterization of human amniotic fluid cells and their differentiation potential. Cell Research, v. 16, n.4, p. 329-336, 2006.

BRILL, S.; HOLST, p.; SIGAL, S.; ZVIBEL, I.; FIORINO, A.; OCHS, A.; SOMASUNDARAN, U.; REID, L.M. Hepatic progenitor populations in embryonic, neonatal, and adult liver. Proceedings of the Society for Experimental Biology and Medicine. v. 204, p. 261-269, 1993. 
BROXMEYER, H.; DOUGLAS, G. W.; HANGOC, G.; COOPER, S.; BARD, J.; ENGLISH, D.; ARNY, L.; THOMAS, L.; BOYSE, E. A. Human umbilical cord blood as a potential source of transplantable hematopoietic stem/progenitor cells. Proceedings of the National Academy of Sciences (USA), v. 86, p. 3828-3832, 1989.

BRUIX, J.; SHERMAN, M. American Association for the Study of Liver Disease. Management of hepatocellular carcinoma: an update. Hepatology, v. 53, n. 3, p. 1020$1022,2010$.

CAPLAN, A. I. Mesenchymal stem cells. Journal of Orthopaedic Research, v. 9, p. 641-650, 1991a.

CAPLAN, A. I. Mesenchymal stem cells: cell-based reconstructive therapy in orthopaedics. Tissue Engineering. v.11, p.1198, 2005 b.

CATAlinA, P.; COBO, F.; CORTÉS, J.L.; NIETO, A.I.; CABRERA, C.; MONTES, R.; CONCHA, A.; MENENDEZ, P. Conventional and molecular cytogenetic diagnostic methods in stem cell research: a concise review. Cell Biology International, v. 31, n. 9, p. 861-869, 2007.

COMAI, L. The advantages and disadvantages of being polyploid. Nature Reviews Genetics, v. 6, n. 11, p. 836-846, 2005.

CONTE, V. P. Carcinoma Hepatocelular. Parte 2. Tratamento. Archives of Gastroenterology, v. 37, p. 133-143, 2000.

COURT, F.G.; WEMYSS-HOLDEN, A.S.; DENNISON, A.R.; MADDERN, G.J. The mystery of liver regeneration. British Journal of Surgery, v. 89, n. 9, p. 1089-1095, 2002. 
COUSIN, B.; RAVET, E.; POGLIO, S.; DE TONI, F.; BERTUZZI, M.; LULKA, H.; TOUIL, I.; ANDRE, M.; GROLLEAU, J.L.; PERON, J.M.; CHAVOIN, J.P.; BOURIN, P.; PENICAUD, L.; CASTEILLA, L.; BUSCAIL, L.; CORDELIER, P. Adult stromal cells derived from human adipose tissue provoke pancreatic cancer cell death both in vitro and in vivo. Plos One, v. 4, n. 7, 2009.

CULLEN, J.M.; MACLACHLAN, N.J.; MCGAVIN, M.D.; CARLTON, W.W.; ZACHARY, J. F. Liver, biliary system, and exocrine pancreas. Special Veterinary Pathology, p. 81-124, 2001.

DAN, Y.Y.; RIEHLE, K.J.; LAZARO, C.; TEOH, N.; HAQUE, J.; CAMPBELL, J.S.; FAUSTO, N. Isolation of multipotent progenitor cells from human fetal liver capable of differentiating into liver and mesenchymal lineages. Proceedings of the National Academy of Sciences of the United States of America, v. 103, n. 26, p. 9912-9917, 2006.

DAZZI, F.; RAMASAMY, R.; GLENNIE, S.; JONES, S.P.; ROBERTS, I. The role of mesenchymal stem cells in haemopoiesis. Blood Reviews, v. 20, n. 3, p. 161-171, 2006.

DENNIS, J.E.; ESTERLY, K.; AWADALLAH, A.; PARRISH, C.R.; POYNTER, G.M.; GOLTRY, K.L. Clinical-scale expansion of a mixed population of bone-marrow-derived stem and progenitor cells for potential use in bone-tissue regeneration. Stem Cells, v. 25, p. 2575-2582, 2007.

DHAWAN, A.; MITRY, R.R.; HUGHES, R.D. Hepatocyte transplantation for liverbased metabolic disorders. Journal of Inherited Metabolic Disease, v.29, p. 431-435, 2006.

DI BISCEGLIE, A. M.; CARITHERS, R. L.; GORES, G. J. Hepatocellular carcinoma. Hepatology, v. 28, p. 1161-1165, 1998.

DI CAMPLI, C.; PISCAGLIA, A. C.; RUTELlA, S.; BONANNO, G.; VECCHIO, F. M.; ZOCCO, M. A.; MONEGO, G.; MICHETTI, F.; MANCUSO, S.; POLA, P.; 
LEONE, G.; GASBARRINI, G.; GASBARRINI, A. Improvement of mortality rate and decrease in histologic hepatic injury after human cord blood stem cell infusion in a murine model of hepatotoxicity. Transplant Proceedings, v. 37, p. 2707-2710, 2005.

DOMINICI, M.; LE BLANC, K.; MUELLER, I.; SLAPER-CORTENBACH, I.; MARINI, F.; KRAUSE, D.; DEANS, R.; KEATING, A.; PROCKOP, D,J.; HORWITZ, E. Minimal criteria for defining multipotent mesenchymal stromal cells. The International Society for Cellular Therapy position statement. Cytotherapy, v. 8, p. 315-317, 2006.

DUESBERG, P.; LI, R.; FABARIUS, A.; HEHLMANN, R. The chromosomal basis of cancer. Cellular Oncology, v. 27, n. 5-6, p. 293-318, 2005.

ECKFELDT, C. E.; MEDENHALL, E. M.; VERFAILLIE, C. M. The molecular repertoire of the 'almighty' stem cell. Nature Reviews Molecular Cell Biology, v. 6, n. 9, p. 726-737, 2005.

EL-SERAG, H.B.; RUDOLPH, K.L. Hepatocellular carcinoma: epidemiology and molecular carcinogenesis. Gastroenterology, v. 132, n. 7, p. 2557-2576, 2007.

FARBER, E. The multistep nature of cancer development. Cancer Research, v. 44, p. 4217-4223, 1984.

FAREEL, G. C.; LARTER, C. Z. Nonalcoholic fatty liver disease: From steatosis to cirrhosis. Hepatology, v. 43, n. 1, p. 99-112, 2006.

FAUSTO, N. Liver regeneration: from laboratory to clinic. Liver Transplantation, v. 7, n. 10, p. 835-844, 2001.

FAZEL, S.; CIMINI, M.; CHEN, L.; LI, S.; ANGOULVANT, D.; FEDAK, P.; VERMA, S.; WEISEL, R. C.; KEATING, A.; LI, R. K. Cardioprotective c-kit+ cells are from the bone marrow and regulate the myocardial balance of angiogenic cytokines. Journal of Clinical Investigation, v. 116, p. 1865 - 1877, 2006. 
FISCHER, R. A.; STROM, S. C. Human hepatocyte transplantation: Worldwide results. Transplantation, v. 82, p. 441-449, 2006.

FRANCAVILlA, A.; OVE, P.; POLIMENO, L.; COETZEE, M.; MAKOWKA, L.; BARONE, M.; VAN THIEL, D.H.; STARZL, T.E. Regulation of the liver size and regeneration: importance in liver transplantation. Transplantation Proceedings, v. 20, n. 1 , c. 1, p. $494-7,1988$.

FRIEDENSTEIN, A. J.; PETRAKOVA, K.V.; KUROLESOVA, A. I.; FROLOVA, G.P. Heterotopic of bone marrow. Analysis of precursor cells for osteogenic and hematopoietic tissues, Transplantation, v. 6, p. 230-247, 1968.

GALlARDO, J.E.; CABRERA, E.A.; RUBIO, B.L.; GONZÁLEZ, V.; CORTÉS, C.A. Gencitabina en 4 pacientes con colangiocarcinoma: Report of four cases. Revista Médica de Chile, Santiago, v. 129, n. 8, agosto de 2001.

GANEM, N.J.; STORCHOVA, Z.; PELLMAN, D. Tetraploidy, aneuploidy and cancer. Current Opinion in Genetics \& Development, v. 17, n. 2, p. 157-162, 2007.

GHIRINGHELLI, F.; LARMONIER, N.; SCHMITT, E.; PARCELLIER, A.; CATHELIN, D.; GARRIDO, C.; CHAUFFERT, B.; SOLARY, E.; BONNOTTE, B.; MARTIN, F. CD4+CD25+ regulatory $\mathrm{T}$ cells suppress tumor immunity but are sensitive to cyclophosphamide which allows immunotherapy of established tumors to be curative. European Journal of Immunology, v. 34, p. 336-344, 2004.

GORLA JR, J.A.; FAGUNDES, D.J.; PARRA, O.M.; ZAIA, C.T.B.V.; BANDEIRA, C.O.P.; TAHA, M.O. Fatores hepatotróficos e regeneração hepática. Parte I: o papel dos hormônios. Acta Cirúrgica Brasileira, v. 16, n. 3, p. 179-184, 2001 a.

GORLA JR, J.A.; FAGUNDES, D.J.; PARRA, O.M.; ZAIA, C.T.B.V.; BANDEIRA, C.O.P.; TAHA, M.O. Fatores hepatotróficos e regeneração hepática. Parte II: fatores de crescimento. Acta Cirúrgica Brasileira, v. 16, n. 4, p. 261-6, 2001 b. 
GRONTHOS, S.; ZANNETTINO, A. C.; HAY, S. J.; SHI, S.; GRAVES, S. E.; KORTESIDIS, A. Molecular and cellular characterisation of highly purified stromal stem cells derived from human bone marrow. Journal of Cell Science, v. 116, p.1827-1835, 2003.

HEDRICH, H.J.; BULLOCK, G. The Laboratory Mouse. The Handbook of Experimental Animals. Elsevier: London, 2004.

HEINDRYCKX, F.; COLLE, I.; VAN VLIERBERGHE, H. Experimental mouse models for hepatocellular carcinoma research. International Journal of Experimental Pathology, v. 90, n. 4, p. 367-386, 2009.

HELMY, A. Review article: Updates in the pathogenesis and therapy of hepatic sinusoidal obstruction syndrome. Alimentary Pharmacology Therapeutics, v. 23, p. 11-25, 2006.

HERRERA, M.B.; BRUNO, S.; BUTTIGLIERI, S.; TETTA, C.; GATTI, S.; DEREGIBUS, M.C.; BUSSOLATI, B.; CAMUSSI, G. Isolation and characterization of a stem cell population from adult human liver. Stem Cells, v. 24, p. 2840-2850, 2006.

HIGASHIYAMA, R.; INAGAKI, Y.; HONG, Y.Y.; KUSHIDA, M.; NIIOKA, M.; WATANABE, T.; OKANO, H.; MATSUZAKI, Y.; SHIOTA, G.; OKAZAKI, I. Bone marrow-derived cells express matrix metalloproteinases and contribute to regression of liver fibrosis in mice. Hepatology, v. 45, p. 213-222, 2007.

HOECHST, B.; VOIGTLAENDER, T.; ORMANDY, L.; GAMREKELASHVILI, J.; ZHAO, F.; WEDEMEYER, H.; LEHNER, F.; MANNS, M.P.; GRETEN, T.F.; KORANGY, F. Myeloid derived suppressor cells inhibit natural killer cells in patients with hepatocellular carcinoma via the NKp30 receptor. Hepatology, v. 50, p. 799-807, 2009. 
HOFFMAN, L.M.; CARPENTER, M.K. Human embryonic stem cell stability. Stem Cell Reviews, v. 1, n. 2, p. 139-144, 2005.

HORWITZ, E. M.; LE BLANC, K.; DOMINICI, M.; MUELLER, I.; SLAPERCORTENBACH, I.; MARINI, F. C. Clarification of the nomenclature for MSC: The International Society for Cellular Therapy position statement. Cytotherapy, v. 7, n.5 p. $393-395,2005$.

HUBSCHER, S.G. Histological assessment of non-alcoholic fatty liver disease. Histopathology, v. 49, p. 450-465, 2006.

HUYNH, H.; CHOW, P. K.H.; SOO, K-C. AZD6244 and doxorubicin induce growth suppression and apoptosis in mouse models of hepatocellular carcinoma. Molecular Cancer Therapeutics, v. 6, n. 9, p. 2468-2476, 2007.

JESUS, R.P.; WAITZBERG, D.L.; CAMPOS, F.G. Regeneração hepática: papel dos fatores de crescimento e nutriente. Revista Associação Médica Brasileira, v. 46, n. 3, p. 242-254, 2000.

JIANG, Y.; JAHAGIRDAR, B.N.; REINHARDT, R.L.; SCHWARTZ, R.E.; KEENE, C.D.; ORTIZ-GONZALEZ, X.R.; REYES, M.; LENVIK, T.; LUND, T.; BLACKSTAD, M.; DU, J.; ALDRICH, S.; LISBERG, A.; LOW, W.C.; LARGAESPADA, D.A.; VERFAILLIE, C.M. Pluripotency of mesenchymal stem cells derived from adult marrow. Nature, v. 418, n. 6893, p. 41-49, 2007.

KELLY, W.R.; JUBB, K.F.V.; KENNEDY, P.C.; PALMER, N. The liver and biliary system. Pathology of domestic animals, v. 2, p. 319-406, 1993.

KEMENY, N. Presurgical chemotherapy in patients being considered for liver resection. The Oncologist, v. 12, p. 825-839, 2007. 
KHAN, A.Z.; MORRIS-STIFF, G.; MAKUUCHI, M. Patterns of chemotherapy-induced hepatic injury and their implications for patients undergoing liver resection for colorectal liver metastases. Journal Hepatobiliary Pancreatic Surgery, v. 16, p. 137-144, 2009.

KÖHN-GAONE, J.; GOGOI-TIWARI, J.; RAMM, G.A.; OLYNYK, J.K.; TIRNITZPARKER, J.E. The role of liver progenitor cells during liver regeneration, fibrogenesis, and carcinogenesis. American Journal of Physiology-Gastrointestinal and Liver Physiology, v. 310, n. 3, p. 143-54; 2016

KOJIRO, M. Pathology of early hepatocellular carcinoma: progression from early to advanced. Hepatogastroenterology, v. 45, n. 13, p. 1203-1205, 1998.

KOLF, C. M.; CHO, E.; TUAN, R. S. Mesenchymal stromal cells. Biology of adult mesenchymal stem cells: regulation of niche, self-renewal and differentiation. Arthritis Research and Therapy, v. 9, n. 1, p. 204, 2007.

KOUNTOURAS, J.; BOURA, P.; LYGIDAKIS, N.J. Liver regeneration after hepatectomy. Hepatogastroenteroly, v. 48, n. 3, p.556-562, 2001.

KWON, A.H.; UETSUJI, S.; YAMAMURA, M.; HIOKI, K.; YAMAMOTO, M. Effect of administration of fibronectin or aprotinin on liver regeneration after experimental hepatectomy. Annals of Surgery, v. 211, n. 3, p. 295-300, 1990.

LÁZARO, C.A.; CROAGER, E.J.; MITCHELL, C.; CAMPBELL, J.S.; YU, C.; FORAKER, J.; RHIM, J.A.; YEOH, G.C.; FAUSTO N. Establishment, characterization, and long-term maintenance of cultures of human fetal hepatocytes. Hepatology, v. 38, p. 1095-1106, 2003.

LEE, J.S.; HEO, J.; LIBBRECHT, L.; CHU, I.S.; KAPOSI-NOVAK, P.; CALVISI, D.F.; MIKAELYAN, A.; ROBERTS, L.R.; DEMETRIS, A.J.; SUN, Z.; NEVENS, F.; ROSKAMS, T.; THORGEIRSSON, S.S. A novel prognostic subtype of human hepatocellular carcinoma derived from hepatic progenitor cells. Nature Medicine, v. 12, 410-416, 2006. 
LEWIS, J.; KLEINSMITH; BARRY PIERCE, G. Multipotentiality of Single Embryonal Carcinoma Cells. Cancer Research, v. 24, p. 1544-1551, 1964.

LI, L.; MIGNONE, J.; YANG, M.; MATIC, M.; PENNMAN, S.; ENIKOLOPOV, G.; HOFFMAN, R.M. Nestin expression in hair follicle sheath progenitor cells. Proceedings of the National Academy of Sciences of the United States of America, v. 100, p. 99589961, 2003.

LLOVET, J. M.; BURROUGHS, A.; BRUIX, J. Hepatocellular carcinoma. The Lancet, v. 362, n. 9399, p. 1907-1917, 2003.

LU, Y.R.; YUAN, Y.; WANG, X.J.; WEI, L.L.; CHEN, Y.N.; CONG, C.; LI, S.F.; LONG, D.; TAN, W.D.; MAO, Y.Q.; ZHANG, J.; LI, Y.P.; CHENG, J.Q. The growth inhibitory effect of mesenchymal stem cells on tumor cells in vitro and in vivo. Cancer biology \& therapy, v. 7, p. 245-251, 2008.

MACHADO, M.C. Hepatocarcinoma. Manual de Condutas Diagnósticas e Terapêuticas em Oncologia, p. 336-348, 2006.

MALHI, H.; IRAINI, A. N.; GAGANDEEP, S.; GPUTA, S. Isolation of human progenitor liver epitelial cells with expansive replication capacity and differentication into mature hepatocyte. Journal of cellular science, v. 115, p. 2679-2688, 2002.

MARTIN, A.P. Management of hepatocellular carcinoma in the age of liver transplantation. International Journal of Surgery, v. 7, n. 4, p. 324-329, 2009.

MARTÍNES, J.; JARUFE, N.; GONZÁLEZ, R.; ÁLVAREZ, M. Current therapeutic options for liver Metastasis. Revista Médica de Chile, Santiago, v. 136, p. 376-384, 2008.

MARTINS, P. N.; NEUHAUS, P. Surgical anatomy of the liver, hepatic vasculature and bile ducts in the rat. Liver International. v. 3, n. 27, p.384-392, 2007. 
MATTOS, A.A.; DANTAS-CORRÊA, E.B. Tratado de Hepatologia. Rio de Janeiro: Rubio, 2010.

MAZZAFERRO, V.; REGALIA, E.; DOCI, R.; ANDREOLA, S.; PULVIRENTI, A.; BOZZETTI, F.; MONTALTO, F.; AMMATUNA, M.; MORABITO, A.; GENNARI, L. Liver transplantation for the treatment of small hepatocelullar carcinomas in patients with cirrhosis. New England Journal of Medicine, v. 334, n. 11, p. 693-699, 1996.

MCCULLOCH, E. A.; TILL, J. E. The Radiation Sensitivity of Normal Mouse Bone Marrow Cells, Determined by Quantitative Marrow Transplantation into Irradiated Mice. Radiation Research, v. 13, n. 1, p 115-125, 1960.

MEISNER, L. F.; JOHNSON, J. A. Protocols for cytogenetic studies of human embryonic stem cells. Methods, v. 45, n. 2, p. 133-141, 2008.

MIAO, Z.; JIN, J.; CHEN, L.; ZHU, J.; HUANG, W.;ZHAO, J.; QIAN, H.; ZHANG, X. Isolation of mesenchymal stem cells from human placenta: Comparison with human bone marrow mesenchymal stem cells. Cell Biology International, v. 30, p. 681-687, 2006.

MICHALANY, J. Regeneração e Metaplasia. In: MICHALANY, J. Anatomia patológica geral - na prática médico-cirúrgica, v. 2, p. 267-274, 2000.

MICHALOPOULOS, G.K.; DEFRANCES, M.C. Liver Regeneration. Science, v. 276, n. 5309, p. 60-6, 1997.

MOSMANN, T. Rapid colorimetric assay for cellular growth and survival: application to proliferation and cytotoxicity assays, v.65, p. 55-63, 1983.

NASCIMENTO, M. C. M. O.; MARTINS, A. S. Cardiomiopatia induzida pela adriamicina: uma revisão. Arquivos de Ciências e Saúde, São José do Rio Preto v. 12, n. 2, p. 111-115, 2005. 
NAVARRO-ALVAREZ, N.; SOTO-GUTIERREZ, A.; KOBAYASHI, N. Hepatic stem cells and liver development. Methods in Molecular Biology, v. 640, p. 181-236, 2010

NAWWAF S.B. CD44 as a potential diagnostic tumor marker. Saudi Medical Journal, v. 36, n. 3, p. 273-279, 2015.

OKADA, K.; OZEKI, K.; TI; ISOMOTO, I. I.; MATSUO, T.; MOCHINAGA, N. Granular Cell Tumor of the Breast: A Case Report Describing Dynamic MR Mammography. Breast Cancer, v. 2, n. 5, p. 179-182, 1998.

ONG, J.P.; YOUNOSSI, Z.M. Epidemiology and natural history of NAFLD and PAESBARBOSA, F.C.; FERREIRA, F.G.; SZUTAN, L.A. Planejamento pré-operatório em hepatectomias. Revista Colégio Brasileiro de Cirurgiões, v. 37, n. 5, 2010.

OTAKE, A.H. Papel de dissialogangliosídeos na proliferação e morte celular induzida de melanócitos e melanoma in vitro [Tese]. São Paulo: Universidade de São Paulo; 2005.

PALMES, D.; SPIEGEL, H. U. Animal models of liver regeneration. Biomaterials, v. 25, n. 9, p.1601-1611, 2004.

PHINNEY, D, G.; PROCKOP, D. J. Concise review: mesenchymal stem/ multipotent stromal cells: the state of transdifferentiation and modes of tissue repair--current views. Stem Cells, v. 25, n. 11, p. 2896-2902, 2007.

PHINNEY, D.G.; PROCKOP, D.J. Concise review: mesenchymal stem/multipotent stromal cells: the state of transdifferentiation and modes of tissue repair - current views. Stem Cells, v.25, p.2896-2902, 2007.

PIMENTA, R.J.; MASSABKI, P.S. Carcinoma hepatocelular: um panorama clínico. Revista Brasileira Clinica Médica, v.8, p. 59-67, 2010. 
PITTENGER, M. F.; MACKAY, A. M.; BECK, S. C.; JAISWAL, R. K.; DOUGLAS, R.; MOSCA, J. D.; MOORMAN, M. A.; SIMONETTI, D. W.; CRAIG, S.; MARSHAK, D. R. Multilineage potential of adult human mesenchymal stem cells. Science, v. 284, n. 5411, p. 143-147, 1999.

PLUNKETT, W.; HUANG, P.; XU, Y. Z.; HEINEMANN, V.; GRUNEWALD, R.; GANDHI, V. Gemcitabine: metabolism, mechanisms of action, and self-potentiation. Seminars in Oncology, v. 22, p. 3-10, 1995.

QIAO, L.; XU, Z.; ZHAO, T.; ZHAO, Z.; SHI, M.; ZHAO, R. C. Suppression of tumorigenesis by human mesenchymal stem cells in a hepatoma model. Cell Research, v. 18 , n. 4, p. 500-507, 2008.

REGE, T.A.; HAGOOD, J.S. Thy-1 as a regulator of cell-cell and cell-matrix interactions in axon regeneration, apoptosis, adhesion, migration, cancer, and fibrosis. Faseb Journal, v. 20, p. 1045-1054, 2006.

RICI, R.G.; ALCÂNTARA, D.; FRATINI, P.; WENCESLAU, C.; AMBRÓSIO, C.E.; MIGLINO, M.A.; MARIA, D.A. Mesenchymal stem cells with rhBMP-2 inhibits the growth of canine osteosarcoma cells BMC Veterinary Research, v. 8, n. 1, p. 17, 2012.

RODASKI, S.; DE NARDI, R.B. Quimioterapia antineoplásica em cães e gatos. Curitiba: Editora Maio, p. 307, 2004.

ROSEN, C.B.; PIMENTEL, S.K.; COELHO, J.C.U. Anatomia e Fisiologia do Fígado. Aparelho Digestivo: Clínica e Cirurgia, v.3, n.2, p. 1185-1192, 2005.

ROTH, L.; DIMSKI, D.S. Interpretation of liver biopsies. The Veterinary Clinics of North America: Small Animal Practice, v. 25, n. 2, p. 293-303, 1995. 
RUDOLPH, K.L.; TRAUTWEIN, C.; KUBICKA, S.; RAKEMANN, T.; BAHR, M.J.; SEDLACZEK, N.; SCHUPPAN, D.; MANNS, M.P. Differential regulation of extracellular matrix synthesis during liver regeneration after partial hepatectomy in rats. Hepatology, v. 30, n. 5, p.1159-1166, 1999.

SAKAIDA, I.; TERAI, S.; YAMAMOTO, N.; AOYAMA, K.; ISHIKAWA, T.; NISHINA, H.; OKITA, K. Transplantation of bone marrow cells reduces CCl4-induced liver fibrosis in mice. Hepatology, v. 40, p.1304-1311, 2004.

SANCHEZ-ROVIRA, P., RAMIREZ-TORTOSA, M. New advances in molecular SCHURGERS, E., KELCHTERMANS, H., MITERA, T., GEBOES, L., MATTHYS, P. Discrepancy between the in vitro and in vivo effects of murine mesenchymal stem cells on T-cell proliferation and collagen-induced arthritis. Arthritis Research \& Therapy, v. 12, n. 1, 2010.

SHARIFF, M. I.; COX, I. J.; GOMAA, A. I.; KHAN, S. A.; GEDROYC, W.; TAYLORROBINSON, S. D. Hepatocellular carcinoma: current trends in worldwide epidemiology, risk factors, diagnosis and therapeutics. Expert Review of Gastroenterology and Hepatology, v. 3, p. 353-367, 2009.

SINGAL, P.K.; ILISKOVIC, N. Doxorubicin-induced cardiomyopathy. The New England Journal of Medicine, v. 339, p. 900-905, 1998.

STORCHOVA, Z.; PELLMAN, D. From polyploidy to aneuploidy, genome instability and cancer. Nature Reviews Molecular Cellular Biology, v. 5, n. 1, p. 45-54, 2004.

STUDENY, M.; MARINI, F. C.; CHAMPLIN, R. E.; ZOMPETTA, C.; FIDLER, I. J.; ANDREEFF, M. Bone marrow-derived mesenchymal stem cells as vehicles for interferon-beta delivery into tumors. Cancer Research, v. 62, n. 13, p. 3603-3608, 2002. 
SUN, F. X.; TANG, Z. Y.; LIU, K. D.; XUE, O.; GAO, D. M.; YU, Y. Q.; ZHOU, X. D.; MA, Z. C. Metastatic models of human liver cancer in nude mice orthotopically constructed by using histologically intact patient specimens. Journal of Cancer Research and Clinical Oncology, v. 122, p. 397-402, 1996.

SUSANECK, S.J. Doxorubicin therapy in the dog. Journal of the American Veterinary Medical Association, v. 182, n. 1, p. 70-72, 1983.

TAKEUCHI, C. A.; TANNURI, U. A polêmica da utilização de células-tronco embrionárias com fins terapêuticos. Revista da Associação Médica Brasileira, v. 52, n. 2, p. 63, 2006.

TARLA, M.R.; RAMALHO, F.; RAMALHO, L.N.Z.; CASTRO e SILVA, T.; BRANDÃO, D.F.; FERREIRA, J.; CASTRO e SILVA, O.; ZUCOLOTO, S. Cellular aspects of liver regeneration. Acta Cirúrgica Brasileira, v. 21, n. 1, p. 63-6, 2006.

TURNER, R.; LOZOYA, O.; WANG, Y.; CARDINALE, V.; GAUDIO, E.; ALPINI, G.; MENDEL, G.; WAUTHIER, E.; BARBIER, C.; ALVARO, D.; REID, L.M. Human hepatic stem cell and maturational liver lineage biology. Hepatology, v. 53, p. 1035$1045,2011$.

TREMOSINI, S.; REIG, M.; DE LOPE, C.R.; FORNER, A.; BRUIX, J. Treatment of early hepatocellular carcinoma: Towards personalized therapy. Digestive and Liver Disease, v. 42, n. 3, p. 242-248, 2010.

UENO, T.; NAKAMURA, T.; TORIMURA, T.; SATA, M. Angiogenic cell therapy for hepatic fibrosis. Medical Molecular Morphology, v. 39, p. 16-21, 2006.

WANG, Y.; YAO, H.L.; CUI, C.B.; WAUTHIER, E.; BARBIER, C.; COSTELLO, M.J.; MOSS, N.; YAMAUCHI, M.; SRICHOLPECH, M.; GERBER, D.; LOBOA, E.; REID, L.M. Paracrine signals from mesenchymal cell populations govern the expansion and differentiation of human hepatic stem cells to adult liver fates. Hepatology, v. 52, p. 1443-1454, 2010 
WEI, W.; CHUA, M. S.; GREPPER, S.; SO, SK. Soluble Frizzled-7 receptor inhibits Wnt signaling and sensitizes hepatocellular carcinoma cells towards doxorubicin. Molecular Cancer, v. 10, n, 16, 2011.

WIESE, C. ROLLETSCHEK, A.; KANIA, G.; BLYSZCZUK, P.; TARASOV, K.V.; WERSTO, R.P, BOHELER, K.R.; WOBUS, A.M. Nestin expression a property of multilineage progenitor cells? Cellular and Molecular Life Sciences, v.19-20, p. 2510-2522, 2004.

WIGHT, D.G.D. Development, anatomy, physiology, patterns of injury. Liver, biliary tract and exocrine pancreas, v. 11, p. 1-52, 1994.

WILLIAMS, K.; MOTIANI, K.; GIRIDHAR, P.V.; KASPER, S. CD44 integrates signaling in normal stem cell, cancer stem cell and (pre)metastatic niches. Experimental Biology and Medicine, v. 238, p. 324-338, 2013.

YU, P. C.; CALDERARO, D.; IKEOKA, D. T.; DEMARCHI, L. M. M. F.; CARAMELli, B. Toxicidade miocárdica por doxorrubicina. Revista da Associação Médica Brasileira, v. 51, n. 3, p.67-74, 2005.

ZHUL, H.; GUO, Z. K; JIANG, X. X.; LI, H.; WANG, X. Y.; YAO, H. Y.; ZHANG, Y.; MAO, N. A protocol for isolation and culture of mesenchymal stem cells from mouse compact bone. Nature Protocols, v. 5, n. 3, 2010.

ZIPORI, D. The nature of stem cells: state rather than entity. Nature Reviews Genetics, v. 5, p. 873-78, 2004.

ZORZI, D.; LAURENT, A.; PAWLIK, T.M.; LAUWERS, G.Y.; VAUTHEY, J.N.; ABADLLA, E.K. Chemotherapy-associated hepatotoxicity and surgery for colorectal liver metastases. British Journal of Surgery, v. 94. p. 274-286, 2007. 